DOE-HTGR-88106

Revision 0

\title{
METALS DESIGN HANDBOOK
}

\author{
DISCLAIMER
}

This report was prepared as an account of work sponsored by an agency of the United States Government. Neither the United States Government nor any agency thereof, nor any of their empleyees, makes any warranty, express or implied, or assumes any legal liability or responsibility for the accuracy, completeness, or usefulness of any information, apparatus, product, or process disclosed, or represents that its use would not infringe privately owned rights. Reference herein to any specific commercial product, process, or service by trade name, trademark, manufacturer, or otherwise does not necessarily constitute or imply its endorsement, recommendation, or favoring by the United States Government or any agency thereof. The views and opinions of authors expressed herein do not necessarily state or reflect those of the United States Government or any agency thereof.

\section{AUTHORS/CONTRACTORS}

\section{GENERAL ATOMICS}

\section{MASTER}

ISSUED BY GENERAL ATOMICS

FOR THE DEPARTMENT OF ENERGY CONTRACT DE-AC03-88SF17367

an $\operatorname{arm}$ 
GA/DOE-130-89

Project 6300

WBS

1603

February 21, 1989

Mr. A. C. Millunzi

U.S. Department of Energy

19901 Germantown Road

Germantown, MD 20874

Subject: Metals Design Handbook

Dear Andy:

Enclosed for your use/information is BOE-HTGR-88106, Rev. 0 , "Metals Design Handbook". Copies have already been sent to $C-E$ and ORNL.

Very truly yours,

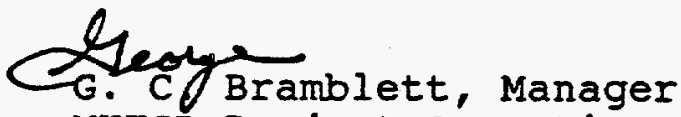

MHTGR Project Operations

Enclosure

cc: E. Arbtin, EG\&G

L. D. Mears, GCRA

B. R. Mills, PDCO

S. L. Wookey, PDCO

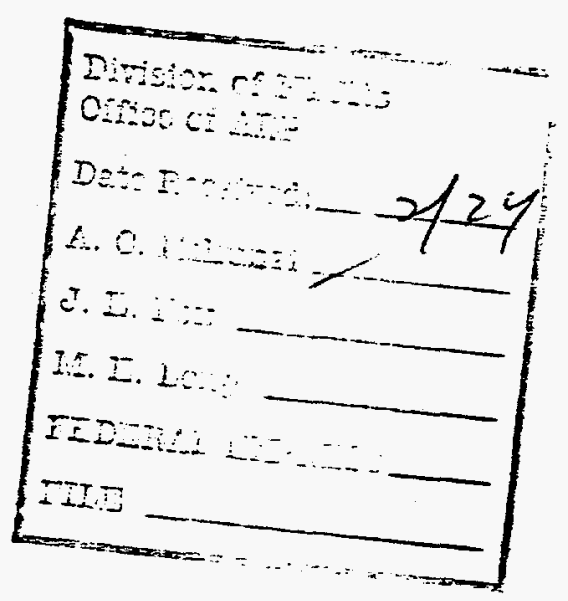




\section{DISCLAIMER}

Portions of this document may be illegible in electronic image products. Images are produced from the best available original document. 
DOCUMENT TRANSMITTAL

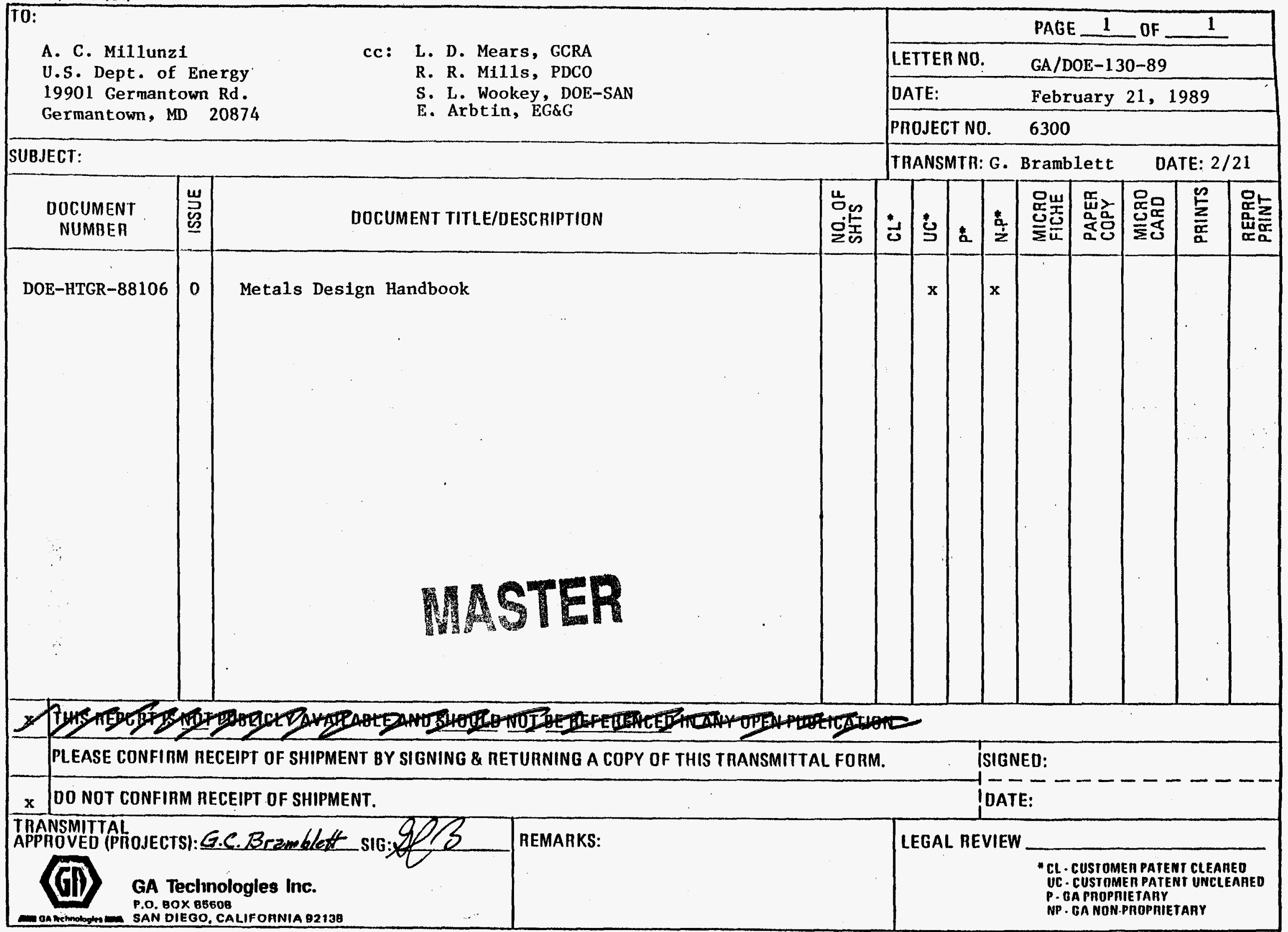

$\therefore$ 
DOE-HTGR-88106

Revision 0

909596/0

\section{METALS DESIGN HANDBOOK}

Issued By:

General Atomics

P.O. Box 85608

San Diego, California 92138-5608

DOE Contract No. DE-AC03-88SF17367

GA Project 6300

JULY 1988 
ISSUE SUMMARY

\begin{tabular}{|c|c|c|c|c|c|}
\hline TITLE & IS DESIG & HANDBOOK & & $\begin{array}{l}\text { 口R\&D } \\
\text { DV\&S } \\
\text { DESIGN }\end{array}$ & APPROVAL LEVEL 5 \\
\hline $\begin{array}{c}\text { DISCIPLINE } \\
0\end{array}$ & $\begin{array}{c}\text { SYSTEM } \\
01\end{array}$ & $\begin{array}{c}\text { DOC.TYPE } \\
\text { MAN }\end{array}$ & $\begin{array}{c}\text { PROJECT } \\
6300\end{array}$ & $\begin{array}{l}\text { DOCUMENT NO. } \\
\text { DOE-ETGR-88106: }\end{array}$ & ISSUE NO./LTR. \\
\hline
\end{tabular}

\begin{tabular}{|c|c|c|c|}
\hline QUALITY ASSURANCE LEVEL & $\begin{array}{c}\text { SAFETY CLASSIFICATION } \\
\text { N/A }\end{array}$ & $\begin{array}{c}\text { SEISMIC CATEGORY } \\
\text { N/A }\end{array}$ & $\begin{array}{c}\text { ELECTRICAL CLASSIFICATION } \\
\text { N/A }\end{array}$ \\
\hline
\end{tabular}

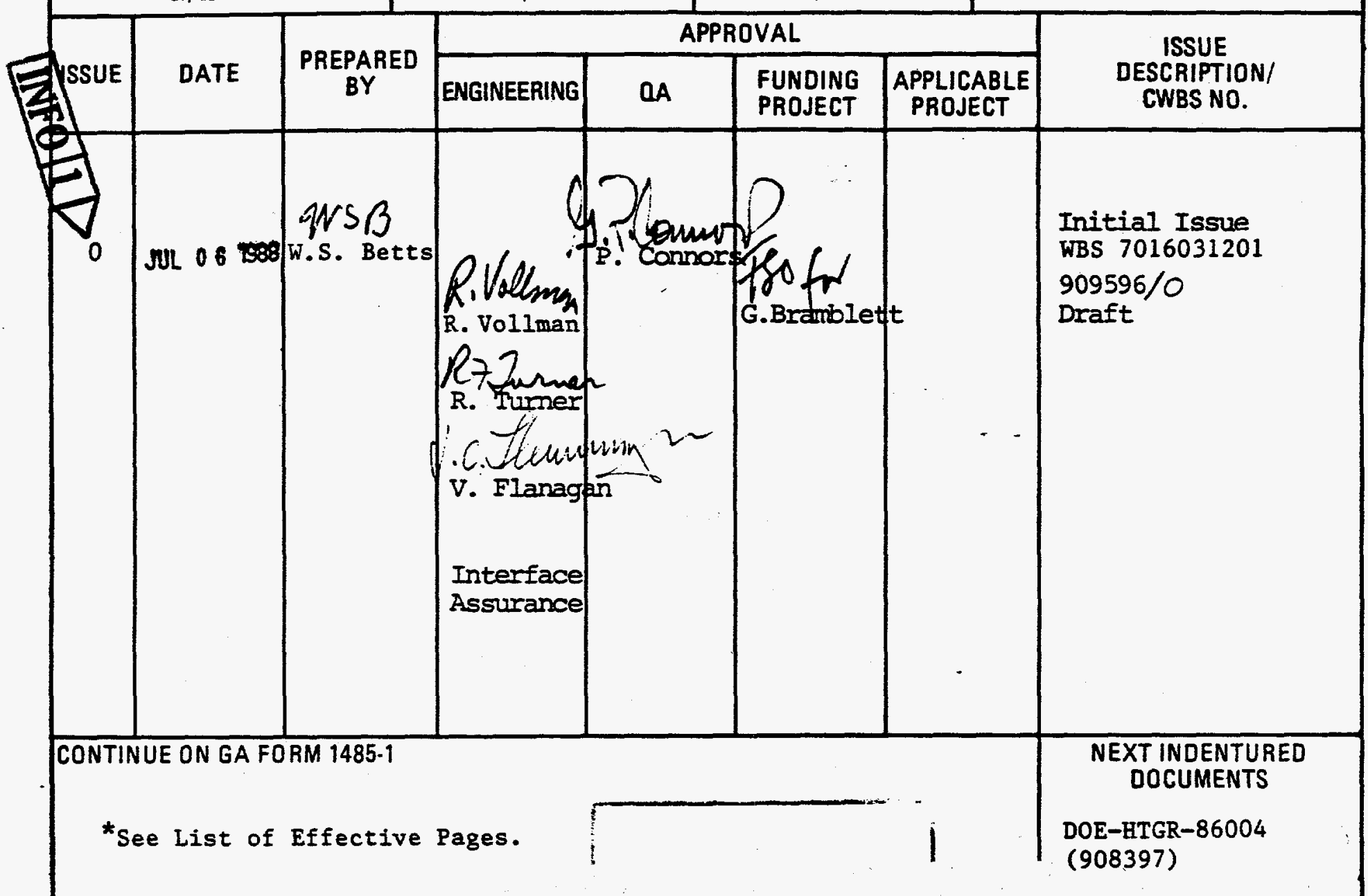


IIST OF EFFECTIVE PAGES

Page Number

i through vili

1-1 through 1-8

2-1 through 2-2

3-1 through 3-33

4-1 through 4-16

5-1 through 5-9

6-1 through 6-10

7-1 through 7-8

Total Pages
Page Count

8

8

2

33

16

9

10

$\underline{8}$

94
Revision

0

0

0

0

0

0

0 
1. INTRODUCTION ....................... 1-1 1.1. Objective .................. 1-1

1.2. Scope .................... 1-. 1-2

1.3. Applicability ................ 1- . 1

1.4. Definition of Symbols and Acronyms ........... 1-3

1.5. References................ 1-4

2. RESPONSIBILITY AND AUTHORITY . . . . . . . . . . . . 2-1

2.1. Responsibility .................. 2-1

2.2. Quality Assurance .................. 2-1

2.3. Change Control ................ 2-1

3. HIGH NICKEL ALLOY, ALIOY 800H . . . . . . . . . . . 3-1

3.1. Product Forms and Applicable Specifications ...... 3-1

3.2. Time-Independent Mechanical Properties ........ 3-1

3.3. Time-Dependent Mechanical Properties . . . . . . . 3-1

3.4. Fatigue Iife . . . . . . . . . . . . 3-4

3.5. Thermal Properties . . . . . . . . . . . 3-5

3.6. Additional Material Properties............ 3-5

3.7. Effects of Primary Coolant Chemistry and Temperature . 3-5

3.7.1. Time-Independent Mechanical Properties . . . . 3-6

3.7.2. Time-Dependent Mechanical Properties . . . . 3-6

3.7.3. Fatigue Life . . . . . . . . . . 3-6

3.7.4. Thermal Properties ............. 3-7

3.7.5. Additional Material Properties........ 3-7

3.8. Effects of Irradiation .............. 3-7

3.8.1. Time-Independent Mechanical Properties ..... 3-7

3.8.2. Time-Dependent Mechanical Properties . . . . 3-8

3.8.3. Fatigue Iffe .............. 3-8

3.8.4. Thermal Properties . . . . . . . . . 3-9

3.8.5. Additional Material Properties......... 3-9

3.9. References . . . . . . . . . . . . . 3-9 
4. IOW ALLOY STEEL, 2-1/4 CI - 1 Mo ............ . 4-1

4.1. Product Forms and Applicable Specifications ...... 4-1

4.2. Time-Independent Mechanical Properties ........ . 4-1

4.3. Time-Dependent Mechanical Properties......... 4-1

4.4. Fatigue Iffe . . . . . . . . . . . . 4-1

4.5. Thermal Properties............... 4-2

4.6. Additional Materlal Properties............ 4-2

4.7. Effect of Primary Coolant Chemistry and Temperatures - 4-2

4.8. Effects of Irradiation . . . . . . . . . . . 4-2

4.9. References ................ 4-. 4

5. THREADED FASTENER MATERIAI SA-638 GRADE 660 (26 Ni -

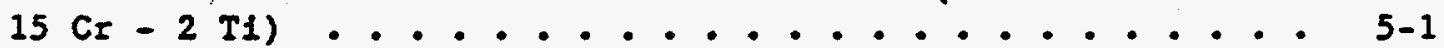

5.1. Applicable Specifications ............ . 5-1

5.2. TIme-Independent Mechanical Properties......... 5-1

5.3. Time-Dependent Mechanical Propertles . . . . . . . 5-1

5.4. Fatigue Iffe.................... 5-2

5.5. Thermal Properties.................. 5-2

5.6. Effect of Primary Coolant Chemistry and Temperature - . 5-2

5.7. Effect of Irradiation .............. 5-2

5.8. References . . . . . . . . . . . . . . 5-2

6. BOLTING MATERIAI SA-193 GRADE B7 (1 CI - 2 MO) ....... 6-1

6.1. Applicable Specifications ............ 6-1

6.2. Time-Independent Mechanical Properties ......... 6-1

6.3. Time-Dependent Mechanical Properties.......... 6-1

6.4. Fatigue Iife... . . . . . . . . . . 6-1

6.5. Thermal Properties ................. 6-1

6.6. Effect of Primary Coolant Chemistry and Temperature . . 6-2

6.7. Effect of Irradiation .............. 6-2

6.8. References..................... 6-2

7. BOLTING MATERIAI SA-453 GRADE 660 (26 N1 - $15 \mathrm{Cr}-2 \mathrm{~T} 1$ ) . - 7-1

7.1. Applicable Specifications ............ 7-1

7.2. Time-Independent Mechanical Properties........ 7-1

7.3. Time-Dependent Mechanical Properties . . . . . . . 7-1

7.4. Fatigue Iffe................... 7-1

7.5. Thermal Properties ............... 7-1 
7.6. Effect of Primary Coolant Chemistry and Temperature - T-2

7.7. Effect of Irradiation . . . . . . . . . . . 7-2

7.8. References ................... 7-2

\section{FIGURES}

3-1. Alloy 800H - Polsson's ratio $(\nu) \ldots \ldots$. . . . . . . 3-23

3-2. Alloy 800日 - typlcal rupture strength . . . . . . . 3-24

3-3. Alloy 800H - minimum stress-to-rupture strength . . . . 3-25

3.4. Alloy 80OH - stress-to-rupture strength given in N-47 . . 3-26

3-5. Allog 800H - $s_{\mathrm{t}}$................... 3-27

3-6. Alloy 800t - $s_{\text {mt }}$. . . . . . . . . . . . . . 3-28

3-7. Alloy 800H - design fatigue straln range, $\epsilon_{\tau}$. . . . . 3-29

3-8. Alloy $800 H$ - design fatigue strain range, $\epsilon_{\tau}$ (elastic analysis) ....................... 3-30

3-9. Alloy 800H - thermal diffusivity ........... 3-31

3-10. Alloy 800H - thermal conductivity .......... 3-32

3-11. Alloy $800 \mathrm{H}$ - specific heat $\left(C_{p}\right)$. . . . . . . 3-33

4-1. 2-1/4 Cr - IMo - design fatigue curves for metal $2 . . .4-13$

4-2. 2-1/4 Cr - 1 Mo - thermel conductivity ........ 4-14

4-3. 2-1/4 Cr - 1 Mo - thermal diffusivity ........ 4-15

4-4. 2-1/4 Cr - 1 Mo - specific heat $\left(C_{p}\right)$. . . . . . . 4-16

6-1. Bolting SA-193 Grade B7 - stress intensity $\left(S_{m}\right)$. . . . . 6-7

6-2. BoltIng SA-193 Grade B7 - thermal conductivity . . . . . 6-8

6-3. BoltIng SA-193 Grade B7 - thermal diffusivity . . . . . 6-9

6-4. Bolting SA-193 Grade B7 - coefficient of thermal

expansion, mean and instantaneous .......... 6-10

\section{TABLES}

1-1. Metallic components of the reactor system and hot duct assembly and their materials .............. 1-5

1-2. Sumary of atructural criteria for metallic components of the reactor system and hot duct assembly . . . . . . 1-6

1-3. ASME code limits and requirements ........... 1-7

1-4. Nomenclature and acronyms ............ 1-8 


\section{TABLES (Continued)}

3-1. Alloy 800H: Minimum specified room temperature tensile properties, product forms, and specificatlons . . . . . 3-11

3-2. Alloy 800H: Chemical composition ........... 3-12

3-3. Alloy 800H: Tensile ultimate strength $\left(S_{u}\right)$, yield strength $\left(S_{y}\right)$, and time-independent design stress Intensity $\left(s_{m}\right)$................... 3-13

3-4. Alloy 800H: Modulus of elasticity ........... 3-14

3-5. Alloy 800H: $S_{t}$ allowable stress intensity values.... . 3-15

3-6. Alloy 800H: $S_{\text {mt }}$ allowable stress Intensity values . . . 3-16

3-7. Alloy 800H: Expected minimum stress-to-rupture values . 3-17

3-8. Alloy 800H: Design fatigue limits . . . . . . . . 3-18

3-9. Alloy 800H: Design fatigue strain range, $\epsilon_{\tau}$ (elastic analysis) ..................... 3-19

3-10. Alloy 800H: Design fatigue strain range, $\epsilon_{\tau}$...... 3-20

3-11. Alloy 800H: Nominal coefficients of thermal conductivity ................ 3-21

3-12. Alloy 800H: Coefficient of thermal expansion . . . . . 3-22

4-1. 2-1/4 Cr - 1 Mo: minimum specified room temperature tensile properties, product forms, and ASME specifications . . 4-3

4-2. 2-1/4 Cr - 1 Mo: chemical composition ......... 4-4

4-3. 2-1/4 Cr - 1 Mo Grade 22 Class 1: tensile ultimate strength $\left(S_{u}\right)$, yield strength $\left(S_{y}\right)$, and time-independent design stress intensity $\left(S_{m}\right)$............ 4-5

4-4. 2-1/4 Cr - $1 \mathrm{Mo:}$ modulus of elasticity ......... 4-6

4-5. 2-1/4 Cr $-1 \mathrm{MO}: S_{t}$ - allowable stress intensity values ................... 4-7

4-6. 2-1/4 Cr - 1 Mo: $S_{\text {mt }}$ - allowable stress intensity values ...................... 4-8

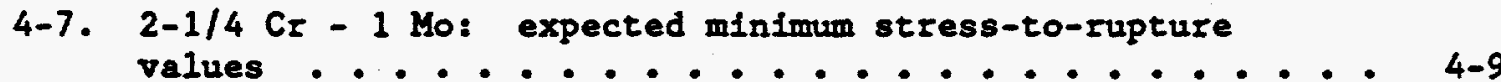

4-8. 2-1/4 $\mathrm{Cr}_{r}-1 \mathrm{Mo}$ : design fatigue strain range, $\epsilon_{\tau}$. . . 4-10

4-9. 2-1/4 Cr - 1 Mo: nominal coefficients of thermal conduc- . tivity (k) and thermal diffusivity (a) ........ 4-11

4-10. 2-1/4 Cr - 1 Ho: coefficient of thermal expansion . . . 4-12

5-1. SA-638 Grade 660: mechanical property requirements. . . 5-3

5-2. SA-638 Grade 660: Chemical composition......... 5-4 
TABLES (Continued)

5-3. SA-638 Grade 660: design stress intensity $\left(S_{m}\right)$ for threaded structural fastener material .......... 5-5

5-4. SA-638 Grade 660: modulus of elasticity . . . . . . . 5-6

5-5. SA-638 Grade 660: design fatigue............ . 5-7

5-6. Nominal coefficients of thermal conductivity (k) and thermal diffusivity (a) for high alloy steel Grade 660 . . 5-8

5-7 Coefficient of thermal expansion for high alloy steel Grade 660 ........................... 5-9

6-1. Bolting material SA-193 Grade B7: chemical composition . . 6-3

6-2. Bolting material SA-193 Grade B7: minimum specified room temperature tensile properties and specifications . . . . 6-4

6-3. Bolting material SA-193 Grade B7: design stress Intensity $\left(S_{\mathfrak{m}}\right)$ values...................... 6-5

6-4. Bolting material SA-193 Grade B7: varfous property values .................. 6-. 6

7-1. Bolting material SA-453 Grade 660: chemical composition ..................... 7-3

7-2. SA-453 Grade 660: mechanical property requirements . . . 7-4

7-3. SA-453 Grade 660: stress-rupture requirements . . . . . 7-5

7-4. Bolting material SA-453 Grade 660: design stress Intensity values $\left(\mathrm{S}_{\mathrm{m}}\right) . . . . . . . . . . . . . . . .7-6$

7-5. Nominel coefficients of thermal conductivity (k) and thermal diffusivity (a) for high alloy steel Grade 660 . . 7-7

7-6. Coefficlent of thermal expansion for high alloy steel Grade 660 .................... 7-8 


\section{INTRODUCTION}

\subsection{OBJECTIVE}

The objectives of the Metals Design Handbook (MDH) are:

1. To provide and maintain a single source of metal properties and material models to be used for design of Modular HighTemperature Gas-Cooled Reactor (MFTGR) metallic Internals components, namely control rods, upper plenum elements, metallic core support, core lateral restraint, upper plenum shroud, hot duct, and circulator outlet shroud.

2. To provide a single source of data and materlal models for use in component design, performance, and safety analyses.

3. To present properties and equations for material models in a form which can be used directly by the designer or analyst without the need for interpretation and are compatible with analytical methods and structural criteria used in the MHTGR project.

4. To control the properties and material models used in the MHTGR design and analysis to proper quality assurance (QA) standards and project requirements. 


\subsection{SCOPE}

This report gives an approved set of material properties over a range of environmental conditions which are sufficient to design the metallic components in the reactor system and hot duct assembly. Table 1-1* Iist these metallic components together with the reference design material chosen for each component. Table 1-2 summarizes the structural criteria of each metallic component taken from the component specifications. In all cases, the criteria references the ASME B\&PV Code (Refs. 1-1 through 1-5).

The ASME-Code includes the material properties of Coded material in Refs. 1-2, 1-4, and 1-5. The Code does not, however, include environmental effects (such as irradiation, corrosion, or thermal aging), and for some components the material maximum allowable temperature is below that of the design and/or postulated "safety-related" accident conditions.

Table 1-3 gives the Code limits for the portions of the Code given in Table 1-2.

This document includes the effects of the radiation environment, chemical impurity effects (in the primary coolant), and the effects of thermal aging and corrosion on the metallic properties.

The design information introduced in this document includes that available from the ASME BEPV Code High-Temperature Code Cases plus material information from General Atomics (GA) and Oak Ridge National Laboratorles (ORNL) that is published.

\footnotetext{
*Tables and figures are located at the end of each section.
} 


\subsection{APPLICABIIITY}

The reference properties presented in this document are approved by the Component Engineering Department for use in MHTGR design, performance, and safety calculation.

\subsection{DEFINITION OF SYMBOLS AND ACRONYMS}

Table 1-4 lists the symbols and ecronyms used in this report. It Is intended that the symbols correspond to those used in the ASME B\&PV Code when applicable. Below is detalled definition of $S_{m}$ and $S_{t}$.

\section{Time-Independent Design Stress Intensity $\left(S_{\mathrm{m}}\right)$}

The value of $S_{m}$ is based on tensile and yleld strengths of the material. The criterla employed are defined as follows.

The allowable stress Intensity value $\left(S_{m}\right)$ for austenitic steels, nickel-chromium-iron and nickel-iron-chromium alloys is the lowest of the following four values:

1. One-third of the specified minimum tensile strength at room temperature.

2. One-third of the tensile strength at operating temperature.

3. Two-thirds of the specifled minimum yleld strength at room temperature.

4. Ninety percent (90\%) of the yleld strength at the operating temperature. 


\section{Time-Dependent Design Stress Intensity $\left(S_{t}\right)$}

The symbol $\mathrm{S}_{t}$ is used for the basic time and temperature-dependent allowable stress intensity for load-controlled stresses. St values are the least of each of the three quantities:

1. Two-thirds of the minimum stress to cause rupture in time $t$.

2. Eighty percent $(80 \%)$ of the minimum stress to cause the onset of tertiary creep in time $t$.

3. The minimum stress to produce 17 total strain in time $t$.

\subsection{REFERENCES}

1-1. ASME Boiler and Pressure Vessel Code, Section III, Division 1, Subsection NG - Core Support Structures, 1986 Edition through the 1987 Addenda.

1-2. ASME Boiler and Pressure Vessel Code, Nuclear Components-Code Case N-201-1, Class CS Components in Elevated Temperature Service, Section III, Division 1, July 16, 1982.

1-3. ASME Boiler and Pressure Vessel Code, Section. III, Division 1, Subsection NB - Class 1 Components, 1986 Edition through the 1987 Addenda.

1-4. ASME Boiler and Pressure Vessel Code, Section III, Division 1, Appendix I, Design Stress Intensity Values, Allowable Stresses, Material Properties, and Design Fatigue Curves, 1986 Edition through the 1987 Addenda.

1-5. ASME Boiler and Pressure Vessel Code Case N-47-23, Class 1 Components on Elevated Temperature Service, Section III, Division 1, February 20, 1986.

1-6. "Reactor System Design Description HTGR," DOE-HTGR-86-035, Rev. 2, Apri1 1988. 
TABLE $1-1$

METALLIC COMPONENTS OF THE REACTOR SYSTEM AND HOT DUCT ASSEMBLY AND THEIR MATERIALS

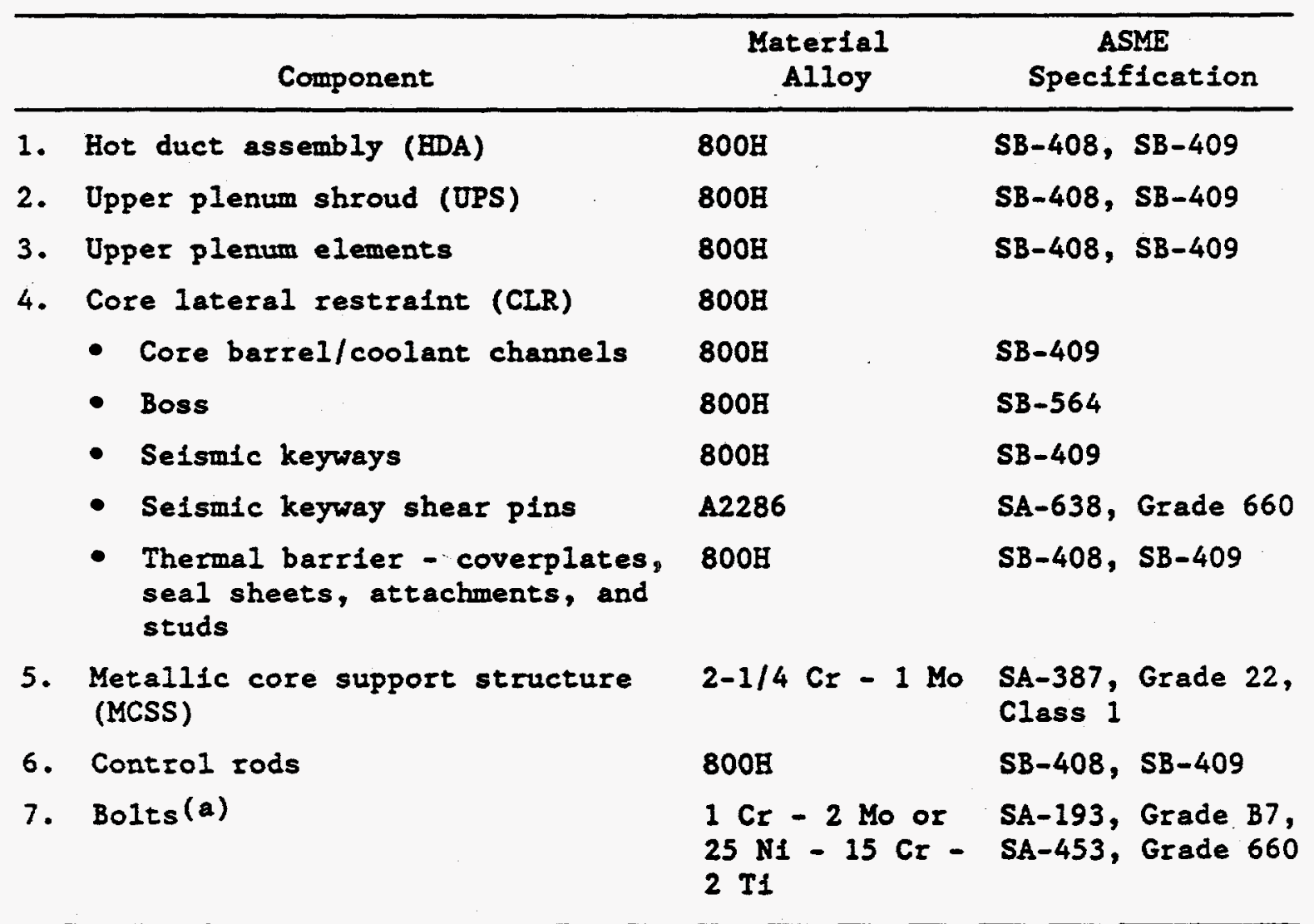

(a) Used in CLR keyways, at the connection between UPS and core barrel (CLR) and in the EDA at the interface between the thermal barrier attachment and the hot duct pipe cylinder. 
TABLE 1-2

SUMMARY OF STRUCTURAL CRITERIA FOR METALLIC COMPONENTS OF THE REACTOR STSTEM AND HOT DUCT ASSEMBLY

\begin{tabular}{llll}
\hline \multicolumn{1}{c}{ Component } & \multicolumn{1}{c}{$\begin{array}{c}\text { ASHE Code Subsection } \\
\text { Section III, Division } 1 \\
\text { (a) }\end{array}$} \\
\hline 1. Hot duct assembly & \multicolumn{1}{c}{$\begin{array}{c}\text { (b) } \\
\text { 2. Opper plenum shroud }\end{array}$} & NG & NB(c), N-47 \\
3. Opper plenum elements & $N-47$ & $N-47$ \\
4. Core lateral restraint & $N G, N-47$ & $N-201(d)$ \\
5. Metallic core support structure & $N G$ & $N-20 I$ \\
6. Control rods & $N-47$ & - \\
\hline
\end{tabular}

(a) Code requirements per Section 3.2 .8 .10 of appropriate design description document (Ref. 1-6).

(b) This column includes additional requirement which are necessary to handle temperature conditions of the component.

(c)During service levels $A$ and $B$ the design temperatures are sufficiently low that Subsection NB can be used. Portions of the hot duct assembly operate at temperature for which Subsection NB is applicable.

(d) Those portions of the core lateral restraint used to support the core must meet H1gh Temperature Code Case N-201 (for Subsection NG). 
TABLE 1-3

ASME CODE LIMITS AND REQUIRUEMENTS

\begin{tabular}{|c|c|c|c|c|c|}
\hline Component & Subsect1on & $\begin{array}{l}\text { Mechanical } \\
\text { Property } \\
\text { Criteria }\end{array}$ & $\begin{array}{l}\text { Permissible } \\
\text { Materfals } \\
\text { (MHTGR) }\end{array}$ & $\begin{array}{l}\text { H1gh Temperature } \\
\text { Code Case }\end{array}$ & $\begin{array}{c}\text { Permissible Mater1als } \\
\text { (MHTGR) }\end{array}$ \\
\hline \multirow[t]{4}{*}{ Class 1} & NB & $1 / 3 s_{u}-2 / 3 s_{y}$ & $\begin{array}{l}2-1 / 4 \mathrm{Cr}-1 \mathrm{Mo} \\
\text { Grade } 22 \mathrm{Class}_{1}(\mathrm{a}) \\
\mathrm{RT}<\mathrm{T} \leq 700^{\circ} \mathrm{F}\end{array}$ & $N-47$ & $\begin{array}{l}2-1 / 4 \mathrm{Cr}-1 \text { Mo Grade } 22 \\
\mathrm{C} 1 \mathrm{as} 8 \mathrm{I} \\
\left\langle 1200^{\circ} \mathrm{F}\right.\end{array}$ \\
\hline & & & $\begin{array}{l}\text { Alloy } 800 \mathrm{H} \\
\mathrm{RT}<\mathrm{T} \leq 800^{\circ} \mathrm{F}\end{array}$ & & $\begin{array}{l}\mathrm{A110y} 800 \mathrm{H} \\
800^{\circ} \mathrm{F}<\mathrm{T} \leq 1400^{\circ} \mathrm{F}\end{array}$ \\
\hline & & & $\begin{array}{l}\text { SA-193 Grade B7 } \\
\text { RT }<T \leq 800^{\circ} \mathrm{F}\end{array}$ & & -- \\
\hline & & & $\begin{array}{l}\text { SA-453 Grade } 660 \\
\mathrm{RT}<\mathrm{T} \leq 800^{\circ} \mathrm{F}\end{array}$ & & -- \\
\hline \multirow[t]{2}{*}{$\begin{array}{l}\text { Core support } \\
\text { structures }\end{array}$} & NG & Same as Class 1 & $\begin{array}{l}2-1 / 4 \mathrm{Cr}-1 \mathrm{Mo} \\
\text { Grade } 22 \mathrm{Class} 1 \\
\mathrm{RT}<\mathrm{T} \leq 700^{\circ} \mathrm{F}\end{array}$ & $N-201$ & - \\
\hline & & & $\begin{array}{l}\text { Alloy } 800 \mathrm{H} \\
\mathrm{RT}<\mathrm{T} \leq 800^{\circ} \mathrm{F}\end{array}$ & & $\begin{array}{l}\text { A11oy } 800 \mathrm{H} \\
800<T \leq 1200^{\circ} \mathrm{F}(\mathrm{t} \leq 20 \mathrm{~h}) \\
T \leq 1100^{\circ} \mathrm{F}(\mathrm{t} \leq 750 \mathrm{~h})\end{array}$ \\
\hline
\end{tabular}

(a) Note: Grade 22 Class 2 is also permissible in Subsections NB and NG, but not on Code Case N-47. 
TABLE $1-4$

NOMENCLATURE AND ACRONYMS

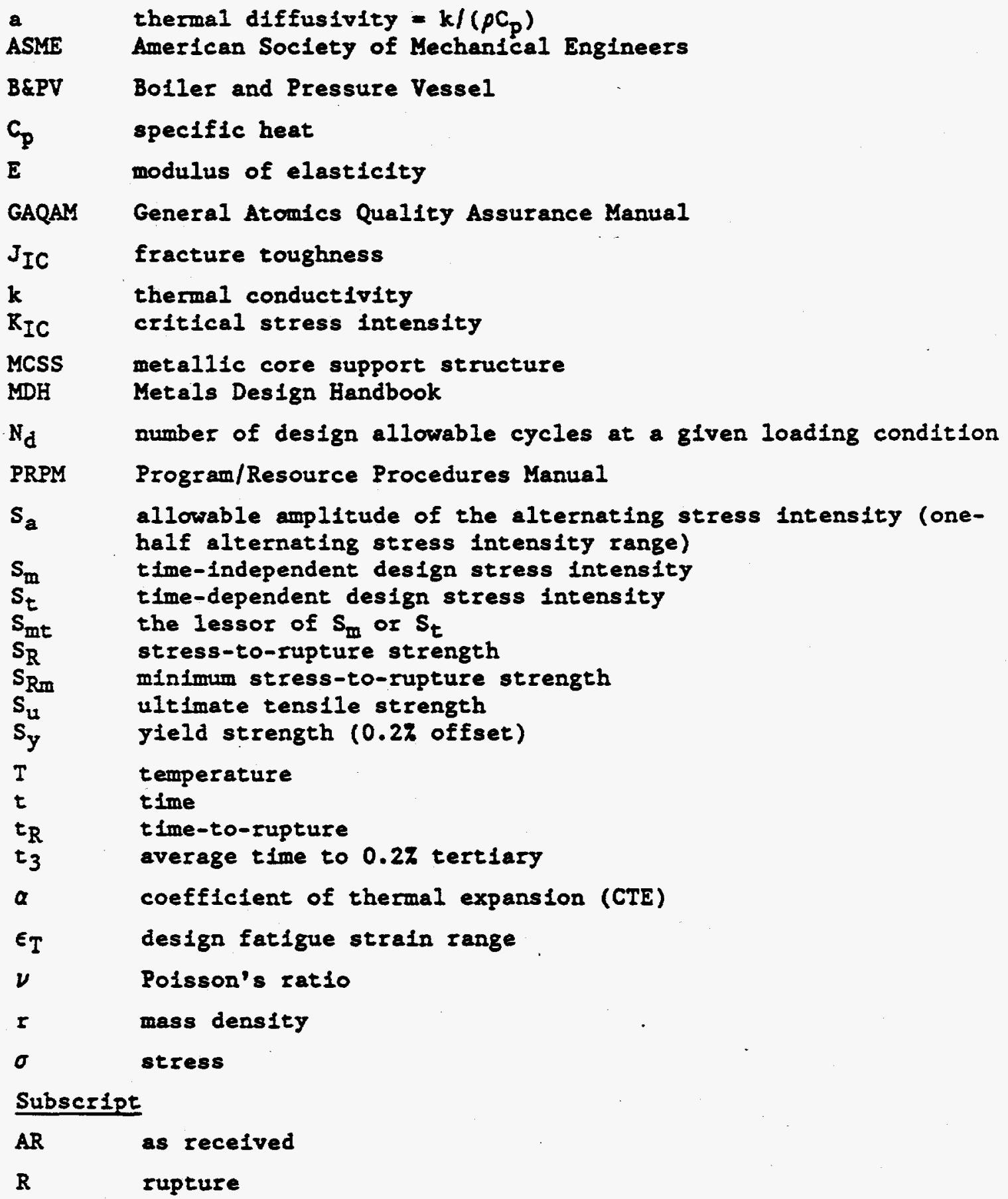




\section{RESPONSIBILITY AND AUTHORITY}

\subsection{RESPONSIBILITI}

Responsibility for maintaining this document is vested in the Manager, Core Engineering Branch, General Atomics.

\subsection{QUALITY ASSURANCE}

This handbook is an GA Approval Level 5 document and shall be approved in accordance with procedure QP-3 given in the GA Quality Assurance Manual (GAQAM) and in the engineering procedures section of the GA Program/Resource Procedures Manual (PRPM).

Material properties must be either obtained from an approved referenceable document or generated from relevant data. Approved documents include the ASME B\&PV Code and other nationally recognized standards. Relevant data must be obtained under conditions which comply with the Quality Assurance Criteria of Appendix B, 10CFR50.

Properties generated from data must be obtained from either of two methods. The first method relies on techniques prevlously used to determine design properties given in the ASME B\&PV Code. The second method relies on a statistical treatment of the data to give a $95 \%$ confidence that exposure to given environment does not degrade a selected property more than the specified amount.

\subsection{CHANGE CONTROL}

Requests for data not now Included in this handbook or for new analyses of data presently incorporated will be made to the manager 
of the Core Engineering Branch within the Component Engineering Department, General Atomics. Data compiled as a response to requests will be approved as required by GAQAM and w111 be issued as required by the GA PRPM. 
3. HIGH NICKEL ALLOY, ALLOY $800 \mathrm{H}$

\subsection{PRODUCT FORMS AND APPLICABLE SPECIFICATIONS}

This product is available in many forms and compositions as shown in Tables 3-1 and 3-2, respectively.

\subsection{TIME-INDEPENDENT MECHANICAL PROPERTIES}

This section includes the following properties of Alloy 800H: $S_{y}$ (Table 3-3), minimum $S_{u}$ (Table 3-3), $S_{m}$ (Table 3-3), E (Table 3-4), and $\nu$ (Fig. $3-1)$.

\subsection{TIME-DEPENDENT MECHANICAI PROPERTIES}

This section includes $S_{t}, S_{m t}$, minimum $S_{R}$, and the associated constitutive creep equations for Alloy $800 \mathrm{H}$.

The constant load creep strain-time behavior of Alloy $800 \mathrm{H}$ can be estimated by the following equation (Sterling's model):

$$
\begin{aligned}
& \tau=\sigma^{\mathrm{U}_{1} / \mathrm{T}_{\epsilon}}\left(\mathrm{U}_{2} / \mathrm{T}+\mathrm{U}_{3}\right) 10\left(\mathrm{U}_{4} / \mathrm{T}+\mathrm{U}_{5}\right), \\
& \log t=D_{1} / T \log \sigma+\left[U_{2} / T+U_{3}\right] \log \epsilon_{c}+D_{4} / T+U_{5}, \\
& \log \epsilon_{c}=\left(\log t-U_{1} / T \log \sigma-\nabla_{4} / T-U_{5}\right) /\left(\nabla_{2} / T+U_{3}\right),
\end{aligned}
$$

$$
\text { where } \begin{aligned}
T & ={ }^{\circ} F+460, \\
\epsilon_{c} & =\text { creep strain }(\pi), \\
\sigma & =\text { stress (ks1), } \\
t & =\text { time (hours). }
\end{aligned}
$$


Per Ref. $3-4$ for $800 \leq{ }^{\circ} \mathrm{F} \leq 1600$

$$
\begin{aligned}
& {\sigma_{1}}_{1}=-14,683.81 \\
& \delta_{2}=10,109.78 \\
& U_{3}=-4.21621 \\
& U_{4}=63,683.08 \\
& U_{5}=-24.4598
\end{aligned}
$$

Per Ref. $3-5$ for $1600<{ }^{\circ} \mathrm{F} \leq 2000$

$$
\begin{aligned}
& \mathrm{v}_{1}=-12,162.6 \\
& \mathrm{U}_{2}=1078.49 \\
& \mathrm{U}_{3}=0.471666 \\
& \mathrm{U}_{4}=51,416.6 \\
& \mathrm{U}_{5}=-19.0780
\end{aligned}
$$

Limitations:

$0 \leq \sigma \leq$ minimum expected ultimate tensile strength at temperature (minimum $S_{u}$ per Table 3-3).

$0 \leq$ time $\leq$ minimum time to 0.22 tertiary creep.

The 0 lower limits apply to the Eq. 1 form. (Log of 0 is undefined.)

The average time to rupture can be estimated from the following equation, per Ref. 3-4:

$$
\log \left(t_{R}+3\right)=-17.628+50160.84 / T-(11781.7 / T) \log S_{R},
$$


The average stress-to-rupture strength can be estimated by solving Eq. 4 for $\log s_{R}$.

$$
\log S_{R}=\left[\log \left(t_{R}+3\right)+17.628-50160.84 / T\right]\left(\frac{-T}{11781.7}\right),
$$

where $t_{R}=$ time to rupture (hour), $t_{R}>0$,

$T={ }^{\circ} \mathrm{F}+460,800 \leq^{\circ} \mathrm{F} \leq 1500$,

$S_{R}=$ average stress-to-rupture strength (ks1).

For temperatures between $1500^{\circ}$ and $2000^{\circ} \mathrm{F}, S_{R}$ can be estimated by solving Eq. 6 .

$$
\begin{aligned}
\log \left(t_{R}+3\right)= & -17.0212+\frac{48158.12}{T} \\
& +\left(0.78572-\frac{12379.81}{T}\right) \log s_{R},
\end{aligned}
$$

The average time to 0.27 tertiary $\left(t_{3}\right)$ can be estimated by the use of the following correlation with time supture:

$$
t_{3}=0.385 t_{R}^{0.994}
$$

The minimum stress-to-rupture strength $\left(S_{R_{m}}\right)$ can be estimated from the following equation:

For $800 \leq{ }^{\circ} \mathrm{F} \leq 1500$ (per Ref. 3-4)

$$
\begin{aligned}
\log S_{R m}= & {\left[\log \left(t_{R}+3\right)+0.566+17.628\right.} \\
& -50160.84 / T]\left(\frac{-T}{11781.7}\right)
\end{aligned}
$$


For $1500<^{\circ} \mathrm{F} \leq 2000$ (per Ref. 3-5)

$$
s_{\mathrm{Rm}}=0.820 s_{\mathrm{R}}
$$

Where $S_{R}$ is from Eq. 6 .

The minimum stress to onset of $0.2 \%$ tertiary creep can be estimated for a given $t_{3}$ by solving $\mathrm{Eq} .7$ for $t_{R}=2.612 t_{3} 1.006$ and substituting in Eq. 8 (average by substituting in Eq. 5).

The typical rupture strength of Alloy $800 \mathrm{H}$ (according to Egs. 5 and 6) for the temperature range of $1200^{\circ}$ to $2000^{\circ} \mathrm{F}$ are presented in Fig. 3-2.

Figure 3-3 give the minimum stress-to-rupture strength $\mathrm{s}_{\mathrm{Rm}}$ based on Eq. 8. Figure 3-4 gives the values of $S_{R m}$ from Ref. 3-6 (N-47). Comparison between these shows that, typically, the values obtained from Eq. 8 (per Ref. 3-4) give somewhat lower $s_{\mathrm{Rm}}$ for a given time and temperature. It is recommended that the more conservative values of $S_{R m}$ from Ref. $3-4$ be used.*

Additional design information from Ref. 3-6 $(N-47)$ is presented in Figs. 3-5 and 3-6, and Tables 3-5 and 3-6.

\subsection{FATIGUE LIFE}

Tables 3-7, 3-8, and 3-9, and Figs. $3-7$ and $3-8$ give design fatigue Iimlts Alloy 800H. Table 3-7 is from Ref. 8 (N-201) and gives allowable stress amplitude $\left(S_{a}\right)$ based on elastic analysis. Table 3-8 and Fig. 3-9 are from Ref. 3-6 $(N-47)$ and gives allowable strain range $\left(\epsilon_{\tau}\right)$ based on elastic analysis. By definftion, $S_{a}=\epsilon_{\tau} /(2 E)$. This relationship can

\footnotetext{
${ }^{*} \mathrm{Mr}$. D. Roberts indicates that he still expects the values from
} Ref. 3-6 to be incorporated into $N-47$. 
be used to show that the $\epsilon_{\tau}$ values in Table 3-8 corresponded exactly to the $S_{a}$ values in Table 3-7. Therefore, the properties in both tables are applicable to both $N-201$ and $N-47$ within the temperature limits of N-201.

The design fatigue strain range in Table 3-9 and Fig. 3-7 is from Ref. 3-6 (N-47) and applies to strains computed using inelastic analysis techniques.

\subsection{THERMAL PROPERTIES}

The following thermal properties shall be used for Alloy 800H: thermal diffusivity (a) (Fig. 3-9), thermal conductivity (k) (Table 3-10; Fig 3-10), and speciflc heat $\left(C_{p}\right)(F 1 g \cdot 3-11)$.

\subsection{ADDITIONAL MATERIAL PROPERTIES}

The coefficients of thermal expansion (a) In Table 3-11 shall be used in design.

\subsection{EFFECTS OF PRIMARY COOLANT CHEMISTRY AND TEMPERATURE}

This section documents the effects of primary coolant chemistry and temperature on the properties of Alloy $800 \mathrm{H}$. The primary coolant helium contains impurities (Ref. 3-5), which can cause corrosion in the form of oxidation, decarburization, and carburization. At design temperatures above $538^{\circ} \mathrm{C}\left(1000^{\circ} \mathrm{F}\right)$, carbon transport in Alloy $800 \mathrm{~B}$ via long-term interaction with the primary coolant helium has been shown to be the most potentially significant mode of corrosion with respect to influencing bulk mechanical properties such as tensile and creep properties. In addition, surface oxidation along with concurrent carbon transport may significantly affect surface sensitive propertles such as fatigue, creep-fatigue, and crack growth. The bases for the values of these properties are given in Section 4.1.3 of Ref. 3-2. 
There is no adverse effect on the es received material properties due to exposure at temperatures less than or equal to $1000^{\circ} \mathrm{F}$. Iong term (up to $300,000 \mathrm{~h}$ ) exposure at temperatures between $1000^{\circ}$ and $1400^{\circ} \mathrm{F}$ are affected as given in the following subsections.

The following sections shall be followed in design.

\subsubsection{Time-Independent Mechanical Properties}

$$
\begin{aligned}
& S_{y}=0.8\left(S_{y}\right)_{A R} \\
& s_{u}=0.8\left(s_{u}\right)_{A R} \\
& S_{m}=0.8\left(S_{m}\right)_{A R} \\
& E \text { is with1n } \neq 20 \% \text { of } E_{A R} \\
& \nu=\nu_{A R}
\end{aligned}
$$

\subsubsection{Time-Dependent Mechanical Properties}

There is no adverse effect on $S_{t}$ and $S_{R m}$.

Therefore,

$$
\begin{aligned}
s_{t} & =\left(s_{t}\right)_{A R} \\
s_{R m} & =\left(s_{R m}\right)_{A R}
\end{aligned}
$$

\subsubsection{Fatigue Iife}

$$
\begin{aligned}
& \epsilon_{T}=0.8\left(\epsilon_{\mathrm{t}}\right)_{\mathrm{AR}} \\
& s_{\mathrm{a}}=0.8\left(\mathrm{~s}_{\mathrm{a}}\right)_{\mathrm{AR}}
\end{aligned}
$$




\subsubsection{Thermal Properties}

There is no adverse effect on $a, k$, or $C_{p}$.

Therefore,

$$
\begin{aligned}
a & =a_{A R} \\
k & =k_{A R} \\
c_{p} & =\left(c_{p}\right)_{A R}
\end{aligned}
$$

\subsubsection{Additional Material Properties}

$$
\begin{aligned}
a & =a_{A R} \\
J_{I C} & \geq 160 \mathrm{~kJ} / \mathrm{m}^{3}\left(900 \mathrm{in.}-1 \mathrm{~b} / \mathrm{ln} .{ }^{2}\right) \\
\mathrm{K}_{I C} & \geq 192 \mathrm{MPa} \sqrt{\mathrm{m}}(175 \mathrm{ks} 1 \sqrt{\mathrm{in}})
\end{aligned}
$$

\subsection{EFFECTS OF IRRADIATION}

This section documents the effects of Irradiation at the design level of Ref. 3-2 on the properties of Alloy $800 \mathrm{H}$. The bases for the values of these properties are given in Section 4.1 .3 of Ref. 3-2. The confidence in these values is adequate for preliminary design.

The following allowable stresses shall be used in design.

\subsubsection{Time-Independent Mechanical Properties}

$$
\begin{aligned}
& s_{y}=0.8\left(s_{y}\right)_{A R} \\
& s_{u}=0.8\left(s_{u}\right)_{A R} \\
& s_{m}=0.8\left(s_{m}\right)_{A R} \\
& E \text { is within } \pm 20 \% \text { of } E_{A R} \\
& \nu=\nu_{A R}
\end{aligned}
$$




\subsubsection{Time-Dependent Mechanical Properties}

For rupture times $\left(t_{R}\right)$ less than $1000 \mathrm{~h}$

$$
\begin{aligned}
s_{t} & =0.8\left(S_{t}\right)_{A R} \\
s_{R m} & =0.8\left(s_{R m}\right)_{A R}
\end{aligned}
$$

For $t_{R} \geq 10,000 \mathrm{~h}$

$$
\begin{aligned}
s_{t} & =\left(s_{t}\right)_{A R} \\
s_{R m} & =0.8\left(s_{R m}\right)_{A R}
\end{aligned}
$$

interpolation on 108 scale for $1,000 \leq t<10,000$ shall be used to compute $S_{t}$ and $S_{R m}$.

\subsubsection{Fatigue Iife}

For $\mathrm{N} \leq 1000$ cycles

$$
\begin{aligned}
& \epsilon_{\tau}=0.5\left(\epsilon_{T}\right)_{A R} \\
& s_{a}=0.5\left(S_{a}\right)_{A R}
\end{aligned}
$$

For $\mathbb{N} \geq 10^{5}$ cycles

$$
\begin{aligned}
& \epsilon_{\tau}=0.8(\epsilon \tau)_{A R} \\
& s_{a}=0.8\left(S_{a}\right)_{A R}
\end{aligned}
$$

Interpolation on 108 scale for $10^{3}<K<10^{5}$ shall be used to compute $\epsilon_{\tau}$ and $s_{a}$. 


\subsubsection{Thermal Properties}

There is no adverse effect on $a, k$, or $C_{p}$.

Therefore,

$$
\begin{aligned}
a & =a_{A R} \\
k & =k_{A R} \\
c_{p} & =c_{\text {PAR }}
\end{aligned}
$$

\subsubsection{Additional Material Properties}

$$
\alpha=a_{\mathrm{AR}}
$$

\subsection{REFERENCES}

3-1. "Preliminary Assessment of Structural Materials for Use at Temperatures in the Range $1200^{\circ}$ to $2000^{\circ} \mathrm{F}$," GA-D15431, Rev. 2, February 1980.

3-2. Betts, W. S. "Metals Technology Development Plan MHTGR," DOEHTGR-86087, Rev. 1, March 1987.

3-3. "Status Report on Creep-Rupture Tests of 2-1/4 Cr - 1 Mo Steel, Alloy $800 \mathrm{H}$ and Hastelloy $X$ in Simulated HTGR-SC/C Helium," DOE-HTGR-85131, Rev. 0, August 1985.

3-4. "HTGR Design Data Manual (Metals and Ceramics)," DOE-HTGR-85048, Rev. O, June 1985.

3-5. "MHTGR-Primary Coolant chemistry-Requirements," DOE-HTGR-88086, Rev. 0, April 1988.

3-6. "ASME Boller and Pressure Vessel Code Case N-47-23, Class 1 Components on Elevated Temperature Service, Section III, Division 1," February 20, 1986.

3-7. "ASME Boller and Pressure Vessel Code, Section III, Division 1," Appendices, 1986 Edition through the 1987 Addenda. 
3-8. "ASME Boller and Pressure Vessel Code Case N-201-1," Class CS Components on Elevated Temperature," July 16, 1982.

3-9. INCO Alloys International, Inc., "Incoloy Alloys 800 and $800 \mathrm{HT}$," Huntington, West Virginia, dated 1986.

3-10. "Criteria for Design of Elevated Temperature Class 1 Components In Section III, Division 1 of the ASME Boiler and Pressure Vessel Code," published by ASME in May 1976. 
TABLE 3-1

ALIOY 800H: MINIMOM SPECIFIED ROOM

TEMPERATURE TENSILE PROPERTIES,

PRODUCT FORMS, AND SPECIFICATIONS

\section{Minimum Specified Tensile Strengths

$\begin{array}{lll}\text { Oltimate } & 65 \mathrm{ksl} & 448 \mathrm{MPa} \\ \text { Yield } & 25 \mathrm{ksi} & 172 \mathrm{MPa}\end{array}$

Typical Applicable Specifications (a)

Form ASTM ASME

Seamless condenser tubing B163 SB-163

Seamless pipe and tubing $B 407 \quad$ SB-407

Rod and bar $\quad$ B408 SB-408

Plate, sheet, and strip B409 SB-409

$\begin{array}{lll}\text { Forgings } & \text { B564 } & \text { SB-564 }\end{array}$

(a) UNS N08810 designation in specification is Incoloy $800 \mathrm{H}$. 
TABLE 3-2

ALIOY 800H: CHEMICAL COMPOSITION, PERCENT BY WEIGET

\begin{tabular}{|c|c|c|}
\hline N1 & & 30 to 35 \\
\hline $\mathrm{Cu}_{\mathbf{u}}$ & Maximum & 0.75 \\
\hline $\mathrm{Fe}$ & & Balance \\
\hline Sin & Maximum & 1.5 \\
\hline C & & 0.05 to 0.10 \\
\hline Si & Maximum & 1.0 \\
\hline $\mathbf{s}$ & Maximum & 0.015 \\
\hline$C_{I}$ & & 19 to 23 \\
\hline 1 & & 0.15 to 0.60 \\
\hline$r$ & & 0.15 to 0.60 \\
\hline Note: & $\begin{array}{l}\text { For Code Case } \\
\text { the following } \\
\text { restrictions }\end{array}$ & $\begin{array}{l}\text { N-47 usage, } \\
\text { additional } \\
\text { apply: }\end{array}$ \\
\hline$A I+I$ & & $\geq 0.507$ \\
\hline Iinimu & solution heat & t. $\quad 2050^{\circ} \mathrm{F}$ \\
\hline
\end{tabular}


TABLE $3-3$

ALIOT 800E: TENSILE ULTIMATE STRENGTE $\left(S_{\mathrm{u}}\right)$, IIELD STRENGTE $\left(S_{y}\right)$, ANB TIME-INDEPENDENT DESIGN STRESS INTENSITY $\left(S_{\text {III }}\right)$

\begin{tabular}{|c|c|c|c|}
\hline \multirow{2}{*}{$\begin{array}{c}\text { Teuperature } \\
\left({ }^{\circ} \mathrm{F}\right)\end{array}$} & \multicolumn{3}{|c|}{ Strength, ks1 } \\
\hline & $s_{u}(a)$ & $s_{y}(b)$ & $S_{m}(c)$ \\
\hline $\begin{array}{r}\text { RT } \\
100 \\
200 \\
300 \\
400\end{array}$ & $\begin{array}{l}65.0 \\
64.0 \\
60.5 \\
58.4 \\
57.0\end{array}$ & $\begin{array}{l}25.0 \\
24.3 \\
22.5 \\
21.1 \\
20.0\end{array}$ & $\begin{array}{l}16.7 \\
16.7 \\
16.7 \\
16.7 \\
16.7\end{array}$ \\
\hline $\begin{array}{r}500 \\
600 \\
\therefore \quad 650 \\
700 \\
750\end{array}$ & $\begin{array}{c}56.0 \\
56.0 \\
=- \\
56.0 \\
\ldots\end{array}$ & $\begin{array}{l}19.0 \\
18.3 \\
17.7 \\
17.5 \\
17.2\end{array}$ & $\begin{array}{c}16.7 \\
16.5 \\
-. \\
15.7 \\
15.5\end{array}$ \\
\hline $\begin{array}{r}800 \\
850 \\
900 \\
950 \\
1000\end{array}$ & $\begin{array}{c}56.0 \\
-- \\
55.5 \\
-- \\
54.6\end{array}$ & $\begin{array}{l}17.0 \\
16.6 \\
16.5 \\
16.2 \\
16.0\end{array}$ & $\begin{array}{l}15.3 \\
15.1 \\
14.8 \\
14.6 \\
14.4\end{array}$ \\
\hline $\begin{array}{l}1050 \\
1100 \\
1150 \\
1200 \\
1250\end{array}$ & $\begin{array}{c}-- \\
51.0 \\
-- \\
46.5 \\
--\end{array}$ & $\begin{array}{l}15.8 \\
15.6 \\
15.5 \\
15.3 \\
15.1\end{array}$ & $\begin{array}{l}14.3 \\
14.1 \\
13.9 \\
13.8 \\
13.5\end{array}$ \\
\hline $\begin{array}{l}1300 \\
1350 \\
1400 \\
1450 \\
1500\end{array}$ & $\begin{array}{r}39.6 \\
36.0 \\
33.0 \\
23.0\end{array}$ & $\begin{array}{l}14.7 \\
14.5 \\
14.0 \\
13.5 \\
13.0\end{array}$ & $\begin{array}{c}13.2 \\
12.0 \\
11.0 \\
-- \\
--\end{array}$ \\
\hline $\begin{array}{l}1550 \\
1600 \\
1700 \\
1800 \\
2000\end{array}$ & $\begin{array}{r}-\overline{1} \\
16.0 \\
11.8 \\
9.0 \\
5.0\end{array}$ & $\begin{array}{l}12.0 \\
11.2 \\
9.0 \\
7.0 \\
4.0\end{array}$ & $\begin{array}{l}-- \\
- \\
- \\
-\end{array}$ \\
\hline
\end{tabular}

(a) For $I \leq 1200^{\circ} \mathrm{g}$. Values of $S_{u}$ are from Ref. 3-4. These values are lower than the ASME code values given in Iable I-3.2 of Ref. 3-7 and Table I-3.2 of Ref. 3-8. At high temperatures, values based on $S_{u}=3 S_{w}$ for $1300 \leq T \leq 1400^{\circ} \mathrm{F}$ and Ref. 3-1 for $T>1400^{\circ} \mathrm{F}$.

(b) Per Table I-2.2, Ref. 3-7, RT $\leq T \leq$ $800^{\circ} \mathrm{F}$, Table I-2.2, Ref. $3-8,800<T \leq$ $1200^{\circ} \mathrm{F}$, Table I-14.5, Ref. $3-6,1200<\mathrm{I} \leq$ $1600^{\circ} \mathrm{F}$, and Ref. $3-1$ for $T>1600^{\circ} \mathrm{F}$.

(c) Per Table I-1.2 of Ref. 3-7 for $T \leq$ $800^{\circ} \mathrm{F}$, Table I-1.2 of Ref. $3-8$ for $800<\mathrm{T} S$ $1200^{\circ} \mathrm{F}$, Table I-14.3 of Ref. $3-6$ for $1200^{\circ}<$ $T \leq 1400^{\circ} \mathrm{F}$. 
TABLE 3-4

AIIOY 800E: MODULUS OF ELASTICITY

\begin{tabular}{cc}
\hline $\begin{array}{c}\text { Temperature } \\
\left({ }^{\circ} \mathrm{F}\right)\end{array}$ & $\begin{array}{c}\text { (Static) } \\
\text { Modulus of Elasticity } \\
\left.\text { (ps1 } \text { (10 }^{-6}\right)\end{array}$ \\
\hline 70 & 28.5 \\
100 & 28.4 \\
200 & 27.8 \\
300 & 27.4 \\
400 & 27.1 \\
500 & 26.6 \\
600 & 26.4 \\
700 & 25.9 \\
750 & 25.7 \\
800 & 25.4 \\
850 & \\
900 & 25.1 \\
950 & 24.8 \\
1000 & 24.5 \\
1050 & 24.2 \\
& 24.1 \\
1100 & \\
1150 & 23.8 \\
1200 & 23.5 \\
1250 & 23.2 \\
1300 & 22.9 \\
1350 & 22.7 \\
1400 & 22.2 \\
1450 & 21.9 \\
1500 & 21.7 \\
\hline$(8)$ & 21.2 \\
\hline
\end{tabular}

(a) Per Table I-14.7 of Ref. 3-6. 
TABLE 3-5

ALLOY 800H: $s_{t}$ ALLOWABLE STRESS INTENSITY VALUES

(ks1)

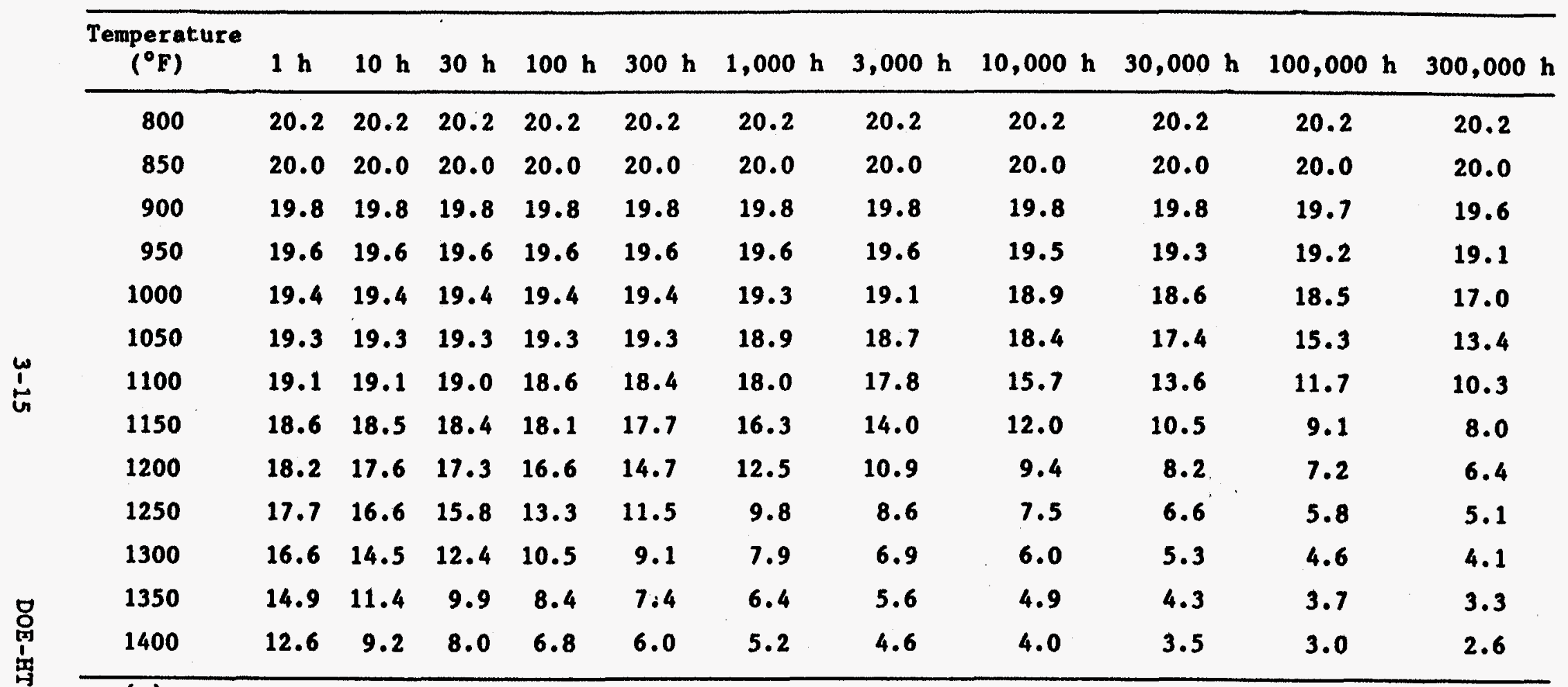

(a) The values in this table are from Table I-14.4C, Ref. 3-6. 
TABLE 3-6

ALLOY 800H: $S_{\mathrm{mt}}$ ALLOWABLE STRESS INTENSITY VALUES

(ksi)

\begin{tabular}{|c|c|c|c|c|c|c|c|c|c|c|c|}
\hline $\begin{array}{c}\text { Temperature } \\
\left({ }^{\circ} \mathrm{F}\right)\end{array}$ & $1 \mathrm{~h}$ & $10 \mathrm{~h}$ & $30 \mathrm{~h}$ & $100 \mathrm{~h}$ & $300 \mathrm{~h}$ & $1,000 \mathrm{~h}$ & $3,000 \mathrm{~h}$ & $10,000 \mathrm{~h}$ & $30,000 \mathrm{~h}$ & $100,000 \mathrm{~h}$ & $300,000 \mathrm{~h}$ \\
\hline 800 & 15.3 & 15.3 & 15.3 & 15.3 & 15.3 & 15.3 & 15.3 & 15.3 & 15.3 & 15.3 & 15.3 \\
\hline 850 & 15.1 & 15.1 & 15.1 & 15.1 & 15.1 & 15.1 & 15.1 & 15.1 & 15.1 & 15.1 & 15.1 \\
\hline 900 & 14.8 & 14.8 & 14.8 & 14.8 & 14.8 & 14.8 & 14.8 & 14.8 & 14.8 & 14.8 & 14.8 \\
\hline 950 & 14.6 & 14.6 & 14.6 & 14.6 & 14.6 & 14.6 & 14.6 & 14.6 & 14.6 & 14.6 & 14.6 \\
\hline 1000 & 14.4 & 14.4 & 14.4 & 14.4 & 14.4 & 14.4 & 14.4 & 14.4 & 14.4 & 14.4 & 14.4 \\
\hline 1050 & 14.3 & 14.3 & 14.3 & 14.3 & 14.3 & 14.3 & 14.3 & 14.3 & 14.3 & 14.3 & 14.3 \\
\hline 1100 & 14.1 & 14.1 & 14.1 & 14.1 & 14.1 & 14.1 & 14.1 & 14.1 & 13.6 & 11.7 & 10.3 \\
\hline 1150 & 13.9 & 13.9 & 13.9 & 13.9 & 13.9 & 13.9 & 13.9 & 12.0 & 10.5 & 9.1 & 8.0 \\
\hline 1200 & 13.8 & 13.8 & 13.8 & 13.8 & 13.8 & 12.5 & 10.9 & 9.4 & 8.2 & 7.2 & 6.4 \\
\hline 1250 & 13.5 & 13.5 & 13.5 & 13.3 & 11.5 & 9.8 & 8.6 & 7.5 & 6.6 & 5.8 & 5.1 \\
\hline 1300 & 13.2 & 13.2 & 12.4 & 10.5 & 9.1 & 7.9 & 6.9 & 6.0 & 5.3 & 4.6 & 4.1 \\
\hline 1350 & 12.0 & 11.4 & 9.9 & 8.4 & 7.4 & 6.4 & 5.6 & 4.9 & 4.3 & 3.7 & 3.3 \\
\hline 1400 & 11.0 & 9.2 & 8.0 & 6.8 & 6.0 & 5.2 & 4.6 & 4.0 & 3.5 & 3.0 & 2.6 \\
\hline
\end{tabular}

(a) The values In this table are from Table I-14.3C of Ref. 3-6. 
TABLE 3-7

ALLOY 800H: EXPECTED MINIMUM STRESS-TO-RUPTURE VALUES (ks1)

Later - values can be obtained from Fig. 3-6. 
TABLE 3-8

ALIOT 800B: DESIGN EATIGJE LIMITS

(Elaste Anelysis)

\section{$\vdots$}

\begin{tabular}{|c|c|c|c|}
\hline \multirow{2}{*}{ No. of Cyeles } & \multirow[b]{2}{*}{$S 800^{\circ} \mathrm{F}$} & \multicolumn{2}{|c|}{$\begin{array}{c}\text { Sa, Allowable } \\
\text { Stress Amplitude } \\
\text { (ks1) }\end{array}$} \\
\hline & & $1000^{\circ} \mathrm{F}$ & $1200^{\circ} \mathrm{F}$ \\
\hline $10^{1}$ & 708.0 & 58.9 & 59.5 \\
\hline $2 \times 10^{1}$ & $\$ 21.0$ & 50.4 & 44.3 \\
\hline $4 \times 10^{1}$ & - & 41.3 & 32.9 \\
\hline $5 \times 10^{-1}$ & 345.0 & $-\infty$ & - \\
\hline $10^{2}$ & 261.0 & 32.9 & 22.5 \\
\hline $2 \times 10^{2}$ & 201.0 & 28.0 & 17.6 \\
\hline $4 \times 10^{2}$ & - & 23.8 & 14.2 \\
\hline $5 \times 10^{-2}$ & 148.0 & - & -- \\
\hline $10^{3}$ & 119.0 & 19.2 & 11.1 \\
\hline $2 \times 10^{3}$ & 97.0 & 16.8 & 9.5 \\
\hline $4 \times 10^{3}$ & -- & 15.1 & 8.5 \\
\hline $5 . \times 10^{4}$ & 76.0 & -- & - \\
\hline $10^{4}$ & 64.0 & 13.0 & 7.5 \\
\hline $2 \times 10^{4}$ & 55.5 & 11.8 & -6.9. \\
\hline $4 \times 10^{4}$ & - & 11.4 & 6.6 \\
\hline $5 \times 10^{4}$ & 46.3 & - & -- \\
\hline $10^{5}$ & 40.8 & 10.7 & 6.2 \\
\hline $2 \times 10^{5}$ & 35.9 & 10.1 & 6.0 \\
\hline $4 \times 10^{5}$ & - & 9.9 & 5.7 \\
\hline $5 \times 10^{5}$ & 31.0 & - & $\cdots$ \\
\hline $10^{6}$ & 28.3 & 9.6 & 5.6 \\
\hline
\end{tabular}

Notes:

1. $\Sigma=26 \times 10^{6} \mathrm{pst}$.

2. The value for temperaturee less than or equal to $800^{\circ} \mathrm{F}$ were obtalned from Table I-9.1 of Ref. 3-7. The values at $I>800^{\circ} \mathrm{I}$ are from Table I-9.2(b), Ref. 3-8.

3. Interpolation between tabular values is permissible based upon data representation by straight lines on 6 log-log plot. Accozdingly, for $s_{1}>S>s_{j}$ :

$$
\left(\frac{N}{N_{1}}=\frac{N_{1}}{N_{1}}\right)^{\left[\log \left(s_{1} / s\right)\right] / \log \left(s_{1} / s_{1}\right)}
$$

Where $s, s_{1}$, and $s_{j}$ are values of $s_{2} ; H, x_{1}$, and $\mathrm{N}_{\mathrm{f}}$ are corresponding numbers of creles Eree design fatigue data. Example: from the data given in the table above, use the Interpolation formula above to flad the number of creles for $S_{2}=84 \mathrm{ksl}$ at $800^{\circ} \mathrm{F}$.

$$
\begin{aligned}
& \frac{\mathrm{x}}{2000}=\left(\frac{5000}{2000}\right)^{(\log (97 / 84)] / \log (97 / 76)} \\
& N=3430 \text { cycles. }
\end{aligned}
$$


TABLE 3-9

ALIOY 800B: DESIGN FATIGUE STRAIN RANGE, $\epsilon_{T}$ (Elastic Analysis)

\begin{tabular}{|c|c|c|c|}
\hline \multirow{2}{*}{ No. of Cycles } & \multicolumn{3}{|c|}{$\begin{array}{c}\epsilon_{\tau} \text { Strain Range (in./in.) } \\
\text { at Temperature }\end{array}$} \\
\hline & $1000^{\circ} \mathrm{E}$ & $1200^{\circ} \mathrm{F}$ & $1400^{\circ} \mathrm{F}$ \\
\hline $\begin{array}{ll} & 10^{1} \\
2 \times 10^{1} \\
4 \times 10^{1}\end{array}$ & $\begin{array}{l}0.00453 \\
0.00388 \\
0.00318\end{array}$ & $\begin{array}{l}0.00458 \\
0.00341 \\
0.00253\end{array}$ & $\begin{array}{l}0.00462 \\
0.00295 \\
0.0019\end{array}$ \\
\hline $\begin{array}{ll} & 10^{2} \\
2 \times 10^{2} \\
4 \times 10^{2}\end{array}$ & $\begin{array}{l}0.00253 \\
0.00215 \\
0.00183\end{array}$ & $\begin{array}{l}0.00173 \\
0.00135 \\
0.00109\end{array}$ & $\begin{array}{l}0.00114 \\
0.000791 \\
0.000581\end{array}$ \\
\hline $\begin{array}{ll} & 10^{3} \\
2 \times 10^{3} \\
4 \times 10^{3}\end{array}$ & $\begin{array}{l}0.00148 \\
0.00129 \\
0.00116\end{array}$ & $\begin{array}{l}0.00085 \\
0.00073 \\
0.00065\end{array}$ & $\begin{array}{l}0.000411 \\
0.000341 \\
0.000291\end{array}$ \\
\hline 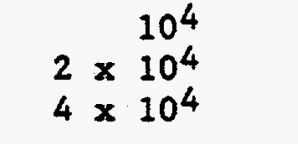 & $\begin{array}{l}0.001 \\
0.00091 \\
0.00088\end{array}$ & $\begin{array}{l}0.00058 \\
0.00053 \\
0.00051\end{array}$ & $\begin{array}{l}0.000251 \\
0.000231 \\
0.000214\end{array}$ \\
\hline $\begin{array}{r}10^{5} \\
2 \times 10^{5} \\
4 \times 10^{5}\end{array}$ & $\begin{array}{l}0.00082 \\
0.00078 \\
0.000765\end{array}$ & $\begin{array}{l}0.00048 \\
0.00046 \\
0.00044\end{array}$ & $\begin{array}{l}0.000201 \\
0.000192 \\
0.000186\end{array}$ \\
\hline $10^{6}$ & 0.00073 & 0.00043 & 0.000181 \\
\hline
\end{tabular}

(a) The values in this table are from Table T-1430-1c of Ref. 3-6 (N-47). 
TABLE 3-10

ALLOY 800H: DESIGN FATIGUE STRAIN RANGE, $\epsilon_{\mathcal{T}}$

\begin{tabular}{|c|c|c|c|c|c|c|c|}
\hline \multirow{2}{*}{$\begin{array}{c}N_{\mathrm{d}} \\
\text { No. of } \\
\text { Cycles (a) }\end{array}$} & \multicolumn{7}{|c|}{$\epsilon_{\tau}$ Strain Range } \\
\hline & $800^{\circ} \mathrm{F}$ & $900^{\circ} \mathrm{F}$ & $1000^{\circ} \mathrm{F}$ & $1100^{\circ} \mathrm{F}$ & $1200^{\circ} \mathrm{F}$ & $1300^{\circ} \mathrm{F}$ & $1400^{\circ} \mathrm{F}$ \\
\hline $\begin{array}{l}\quad 10^{1} \\
2 \times 10^{1} \\
4 \times 10^{1}\end{array}$ & $\begin{array}{l}0.0513 \\
0.0328 \\
0.0218\end{array}$ & $\begin{array}{l}0.0498 \\
0.0313 \\
0.0208\end{array}$ & $\begin{array}{l}0.0468 \\
0.0298 \\
0.0190\end{array}$ & $\begin{array}{l}0.0378 \\
0.0243 \\
0.0163\end{array}$ & $\begin{array}{l}0.0308 \\
0.0198 \\
0.0130\end{array}$ & $\begin{array}{l}0.0263 \\
0.0168 \\
0.0113\end{array}$ & $\begin{array}{l}0.0231 \\
0.0129 \\
0.00866\end{array}$ \\
\hline $\begin{array}{r}10^{2} \\
2 \times 10^{2} \\
4 \times 10^{2}\end{array}$ & $\begin{array}{l}0.0139 \\
0.0103 \\
0.00777\end{array}$ & $\begin{array}{l}0.0219 \\
0.00939 \\
0.00699\end{array}$ & $\begin{array}{l}0.0119 \\
0.00861 \\
0.00641\end{array}$ & $\begin{array}{l}0.01 \\
0.00722 \\
0.00542\end{array}$ & $\begin{array}{l}0.00823 \\
0.00603 \\
0.00463\end{array}$ & $\begin{array}{l}0.00725 \\
0.00535 \\
0.00405\end{array}$ & $\begin{array}{l}0.00566 \\
0.00426 \\
0.00331\end{array}$ \\
\hline $\begin{array}{r}10^{3} \\
2 \times 10^{3} \\
4 \times 10^{3}\end{array}$ & $\begin{array}{l}0.00537 \\
0.00427 \\
0.00347\end{array}$ & $\begin{array}{l}0.00489 \\
0.00379 \\
0.00314\end{array}$ & $\begin{array}{l}0.00441 \\
0.00351 \\
0.00291\end{array}$ & $\begin{array}{l}0.00392 \\
0.00312 \\
0.00259\end{array}$ & $\begin{array}{l}0.00328 \\
0.00261 \\
0.00213\end{array}$ & $\begin{array}{l}0.00285 \\
0.0023 \\
0.00195\end{array}$ & $\begin{array}{l}0.00254 \\
0.00209 \\
0.00176\end{array}$ \\
\hline $\begin{array}{r}10^{4} \\
2 \times 10^{4} \\
4 \times 10^{4}\end{array}$ & $\begin{array}{l}0.00277 \\
0.00242 \\
0.00215\end{array}$ & $\begin{array}{l}0.00249 \\
0.00219 \\
0.00193\end{array}$ & $\begin{array}{l}0.00233 \\
0.00201 \\
0.0018\end{array}$ & $\begin{array}{l}0.0021 \\
0.00182 \\
0.00162\end{array}$ & $\begin{array}{l}0.00174 \\
0.00155 \\
0.0014\end{array}$ & $\begin{array}{l}0.00159 \\
0.00142 \\
0.00127\end{array}$ & $\begin{array}{l}0.00143 \\
0.00125 \\
0.00109\end{array}$ \\
\hline $\begin{array}{r} \\
2 \times 5 \\
2 \times 10^{5} \\
4 \times 10^{5}\end{array}$ & $\begin{array}{l}0.00187 \\
0.00169 \\
0.00157\end{array}$ & $\begin{array}{l}0.00164 \\
0.00149 \\
0.00139\end{array}$ & $\begin{array}{l}0.00151 \\
0.00141 \\
0.00129\end{array}$ & $\begin{array}{l}0.00139 \\
0.00128 \\
0.00121\end{array}$ & $\begin{array}{l}0.00122 \\
0.00113 \\
0.00108\end{array}$ & $\begin{array}{l}0.00115 \\
0.00105 \\
0.000987\end{array}$ & $\begin{array}{l}0.000959 \\
0.000919 \\
0.000889\end{array}$ \\
\hline $10^{6}$ & 0.00139 & 0.00129 & 0.00119 & 0.00112 & 0.00103 & 0.000937 & 0.000869 \\
\hline
\end{tabular}

(a) Cyclic strain rate: $1 \times 10^{-3}$ in./in./s.

(b) The values in this table are from Table T-1420-IC, Ref. 3-6. 
TABLE 3-11

ALIOY 800E: NOMINAI COEFFICIENTS

OF THERMAL CONDUCTIVITY

\begin{tabular}{|c|c|}
\hline Temperature $\left({ }^{\circ} \mathrm{F}\right)$ & $\mathbf{k}(\mathbf{a})$ \\
\hline $\begin{array}{r}70 \\
100 \\
150 \\
200 \\
250\end{array}$ & $\begin{array}{l}6.7 \\
6.8 \\
7.1 \\
7.4 \\
7.7\end{array}$ \\
\hline $\begin{array}{l}300 \\
350 \\
400 \\
450 \\
500\end{array}$ & $\begin{array}{l}8.0 \\
8.3 \\
8.6 \\
8.8 \\
9.1\end{array}$ \\
\hline $\begin{array}{l}550 \\
600 \\
650 \\
700 \\
750\end{array}$ & $\begin{array}{r}9.3 \\
9.6 \\
9.8 \\
10.1 \\
10.3\end{array}$ \\
\hline $\begin{array}{r}800 \\
850 \\
900 \\
950 \\
1000\end{array}$ & $\begin{array}{l}10.6 \\
10.8 \\
11.1 \\
11.3 \\
11.6\end{array}$ \\
\hline $\begin{array}{l}1050 \\
1100 \\
1150 \\
1200 \\
1250\end{array}$ & $\begin{array}{l}11.9 \\
12.1 \\
12.4 \\
12.7 \\
13.0\end{array}$ \\
\hline $\begin{array}{l}1300 \\
1350 \\
1400 \\
1450 \\
1500 \\
1600 \\
1800\end{array}$ & $\begin{array}{l}13.2 \\
13.2 \\
13.8 \\
14.2 \\
14.5 \\
15.1 \\
17.3\end{array}$ \\
\hline
\end{tabular}

(a)k is thermal conductivity, Btu/h ft ${ }^{\circ}$. Values for $I \leq 1500^{\circ} \mathrm{F}$ are per Table I-4 of Ref. 3-7 values for $T>1500^{\circ} \mathrm{F}$ are from Ref. 3-1. For $T \leq$ $1500^{\circ} \mathrm{F}, \mathrm{k} \approx 6.3+5.4 \mathrm{x}$ $10^{-3} \mathrm{~T}$. 
TABLE 3-12

ALIOY 800H: COEFFICIENT OF THERMAL EXPANSION

\begin{tabular}{|c|c|c|}
\hline \multirow{2}{*}{$\begin{array}{c}\text { Temperature } \\
\left({ }^{\circ} \mathrm{F}\right)\end{array}$} & \multicolumn{2}{|c|}{$\begin{array}{l}\text { Coefficient of Thermal Expansion } \\
\left(\text { In./1n. }-{ }^{\circ} F \times 10^{-6}\right)\end{array}$} \\
\hline & $\operatorname{Mean}(a)(b)$ & Instantaneous (c) \\
\hline $\begin{array}{r}70 \\
100 \\
200 \\
300 \\
400\end{array}$ & $\begin{array}{l}7.75 \\
7.79 \\
7.90 \\
8.30 \\
8.80\end{array}$ & $\begin{array}{l}7.75 \\
8.05 \\
8.50 \\
8.80 \\
9.00\end{array}$ \\
\hline $\begin{array}{l}500 \\
600 \\
700 \\
750 \\
800\end{array}$ & $\begin{array}{l}8.90 \\
9.00 \\
9.10 \\
9.15 \\
9.20\end{array}$ & $\begin{array}{l}9.12 \\
9.20 \\
9.32 \\
9.40 \\
9.50\end{array}$ \\
\hline $\begin{array}{r}850 \\
900 \\
950 \\
1000 \\
1050\end{array}$ & $\begin{array}{l}9.25 \\
9.30 \\
9.35 \\
9.40 \\
9.45\end{array}$ & $\begin{array}{r}9.65 \\
9.80 \\
9.97 \\
10.16 \\
10.37\end{array}$ \\
\hline $\begin{array}{l}1100 \\
1150 \\
1200 \\
1250 \\
1300\end{array}$ & $\begin{array}{l}9.50 \\
9.55 \\
9.60 \\
9.65 \\
9.70\end{array}$ & $\begin{array}{l}10.60 \\
10.80 \\
11.00 \\
11.20 \\
11.37\end{array}$ \\
\hline $\begin{array}{l}1350 \\
1400 \\
1450 \\
1500 \\
1550\end{array}$ & $\begin{array}{r}9.77 \\
9.84 \\
9.91 \\
10.00 \\
10.10\end{array}$ & $\begin{array}{l}11.54 \\
11.68 \\
11.80 \\
11.92 \\
12.00\end{array}$ \\
\hline 1600 & 10.20 & 12.10 \\
\hline
\end{tabular}

(a) The mean coefficient of thermal expansion at temperature (T) 18 given by:

$$
\frac{\text { Length at } T-\text { length at } 70^{\circ} \mathrm{F}}{\text { (Length at } \left.70^{\circ} \mathrm{F}\right)\left(\mathrm{T}-70^{\circ} \mathrm{F}\right)}
$$

(b) Per Table I-14.9 of Ref. 3-6.

(c) Per Table I-14.8 of Ref. 3-6. 


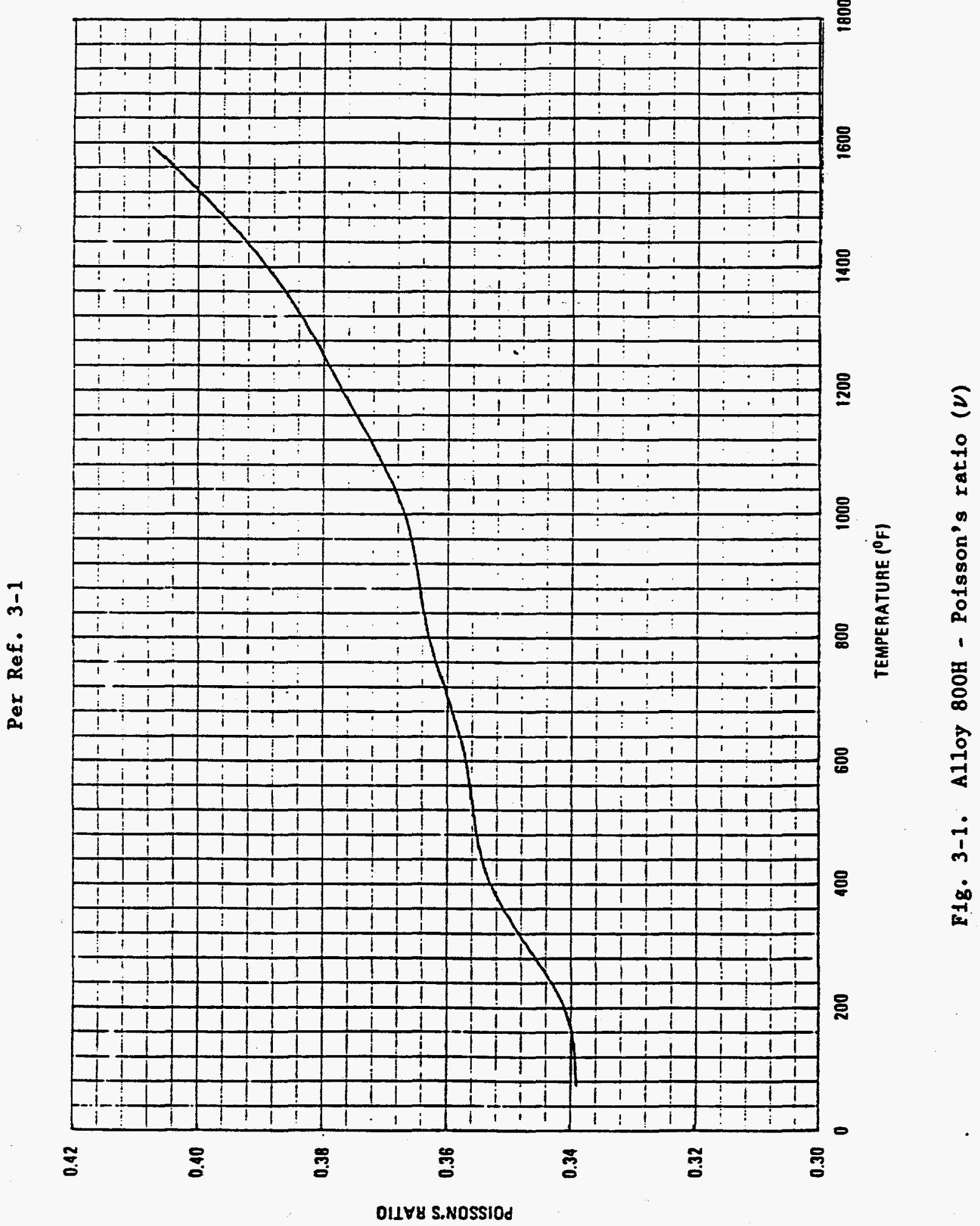




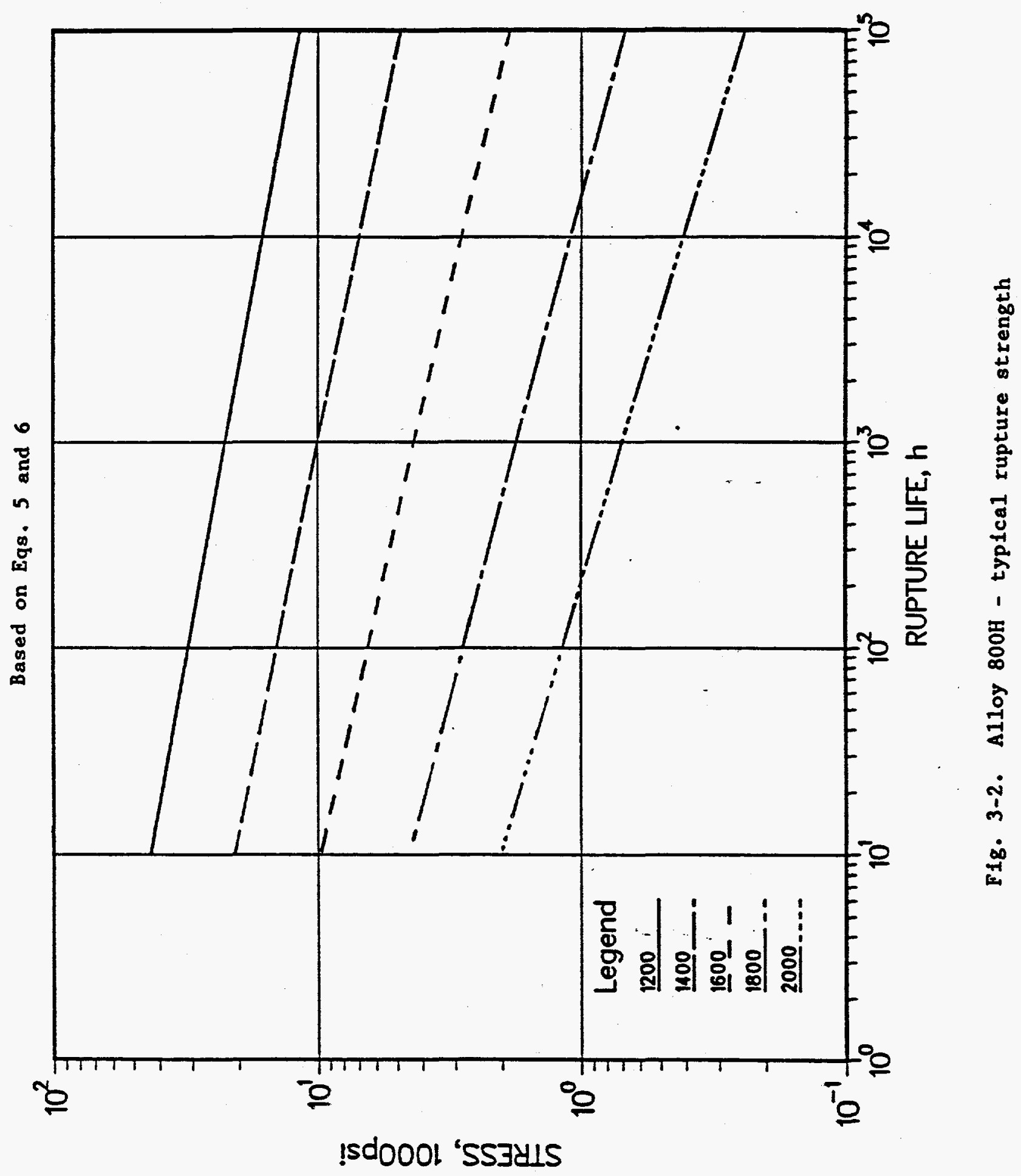




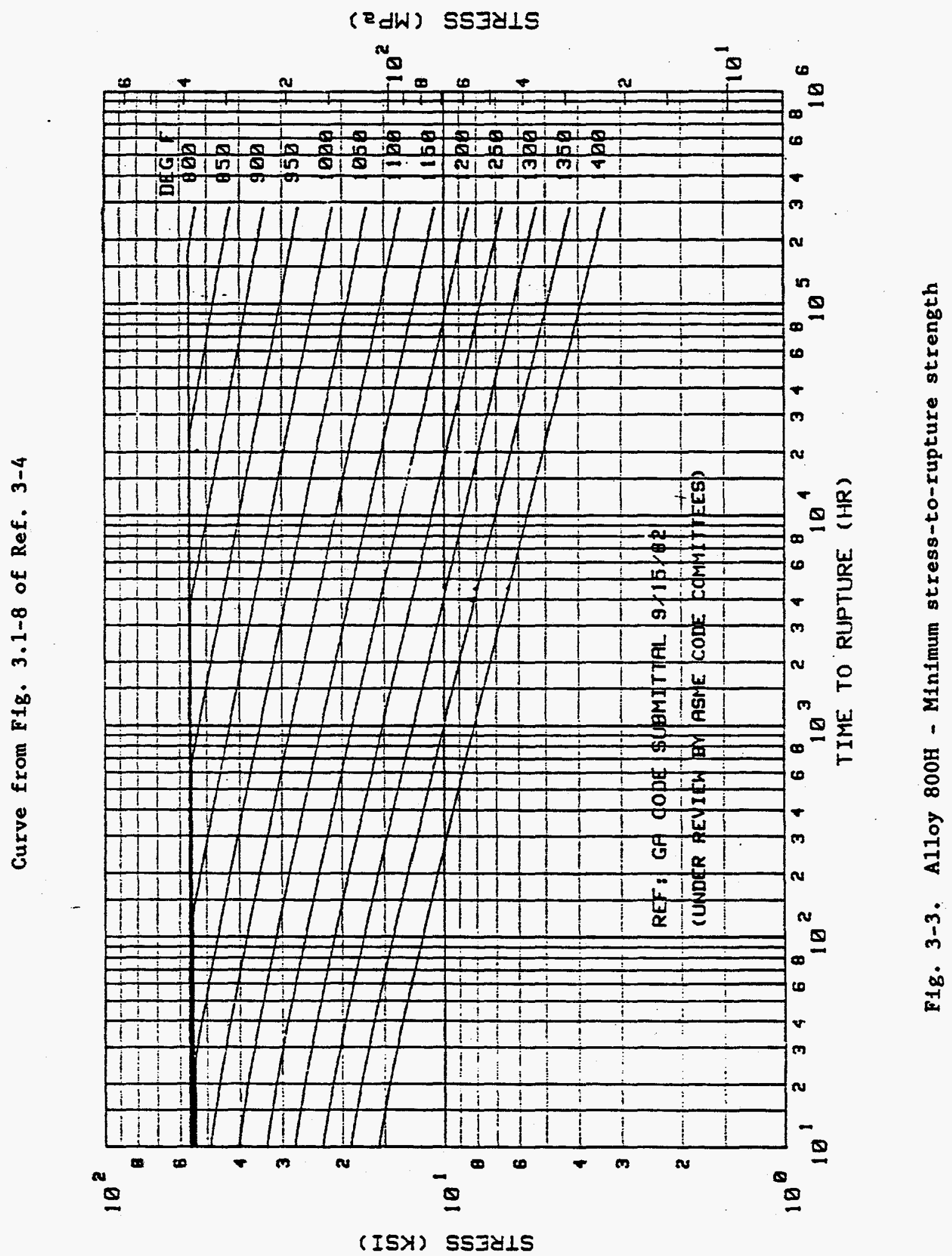


From Fig. I-14.6, Ref. 3-6

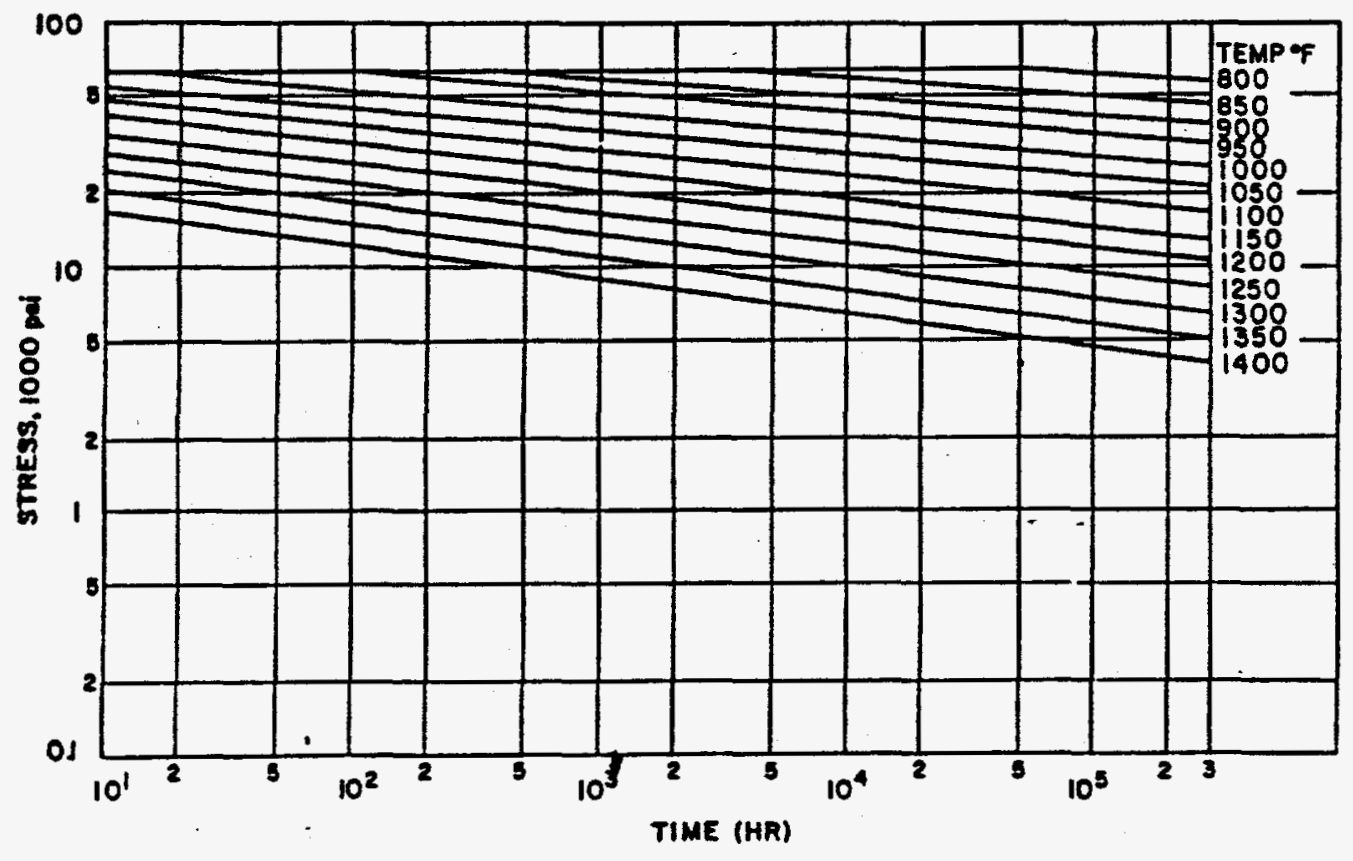

Fig. 3-4. Alloy 800H - stress-to-rupture strength given in N-47 
From Fig. I-14.4C, Ref. 3-6

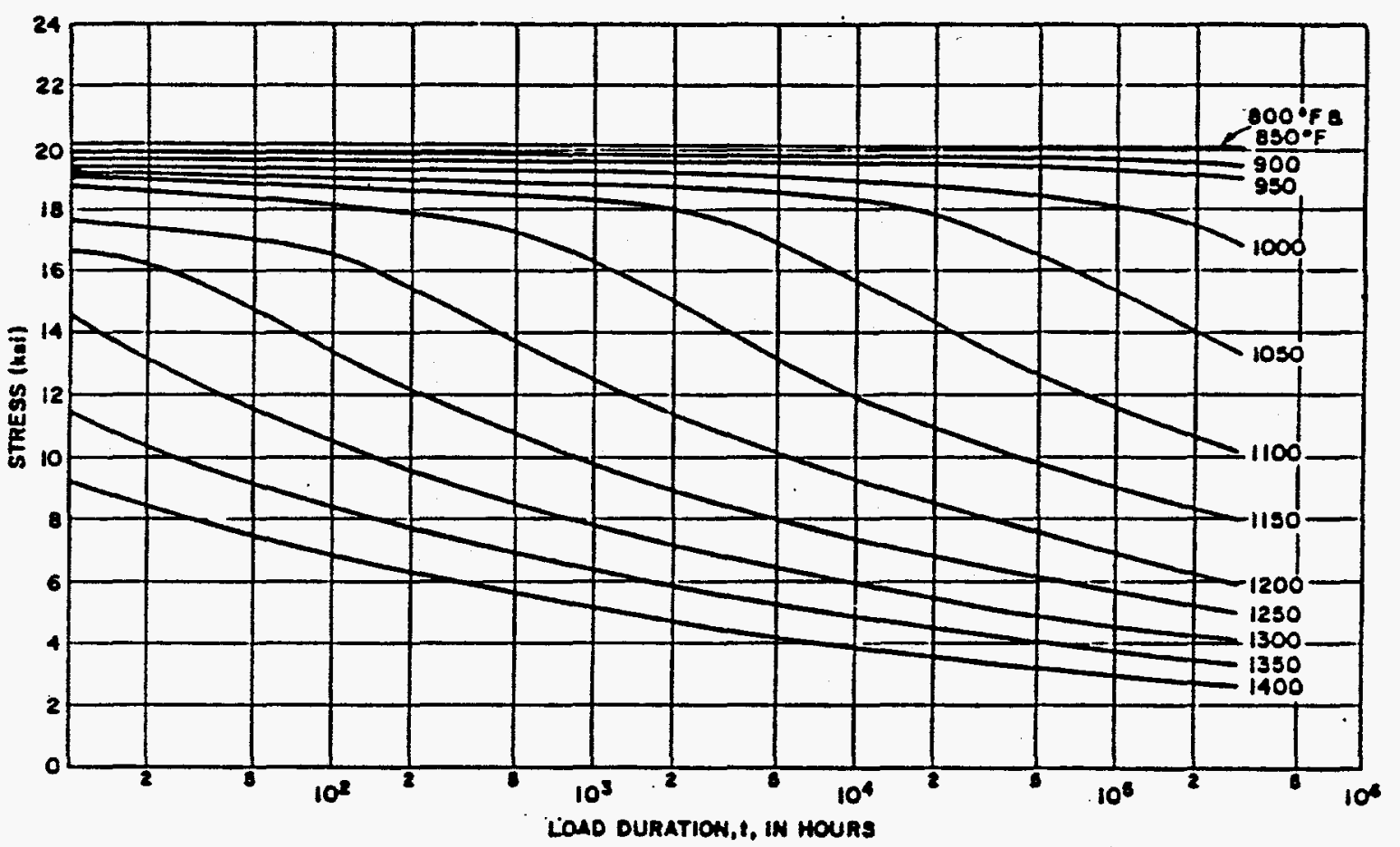

Fig. 3-5. Alloy $800 \mathrm{H}-S_{t}$ 
From F1g. I-14.3C, Ref. 6

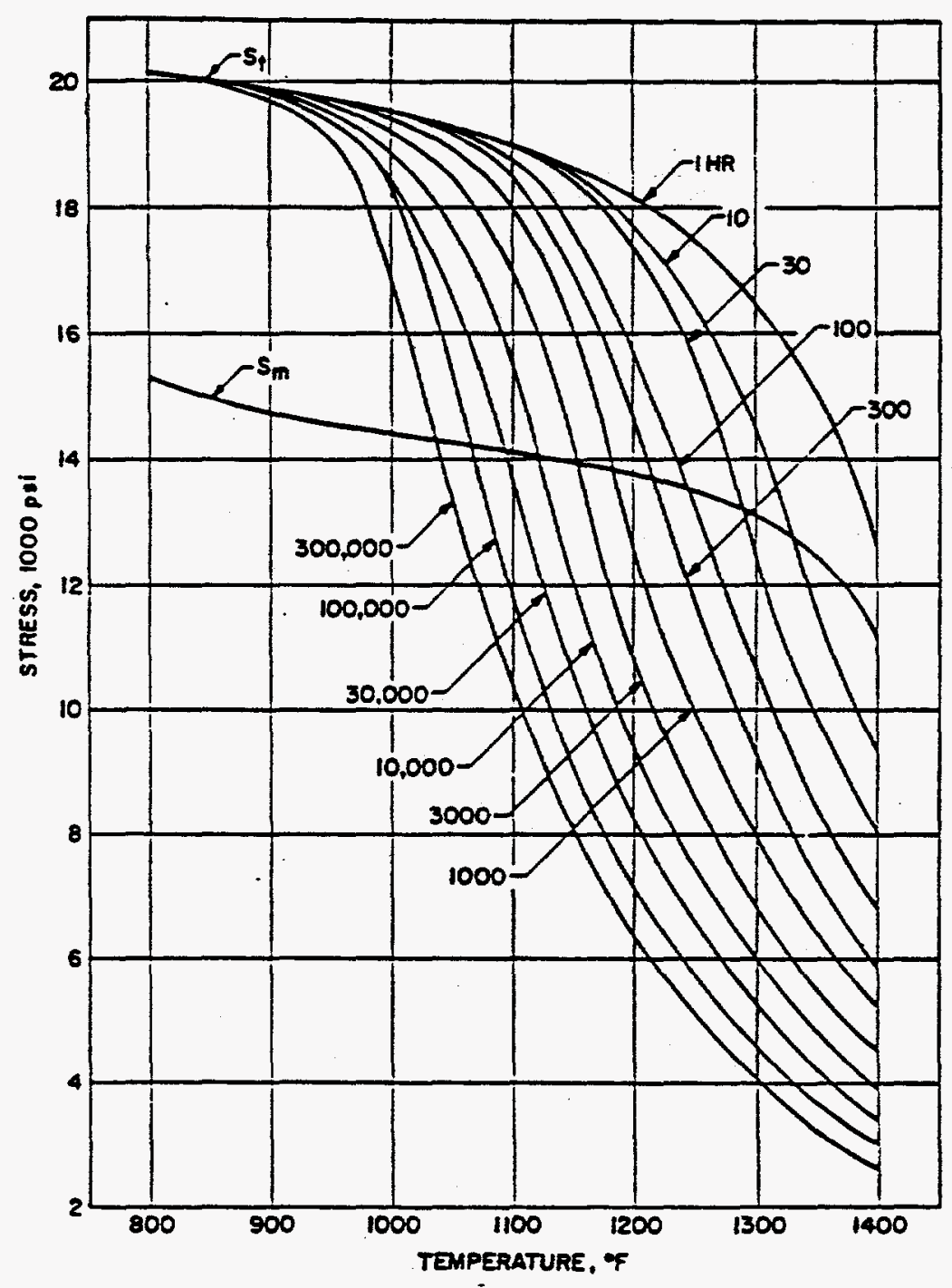

Fig. 3-6. Alloy $800 \mathrm{H}-S_{\text {mt }}$ 
From F1g. I-1420-1C, Ref. 3-6

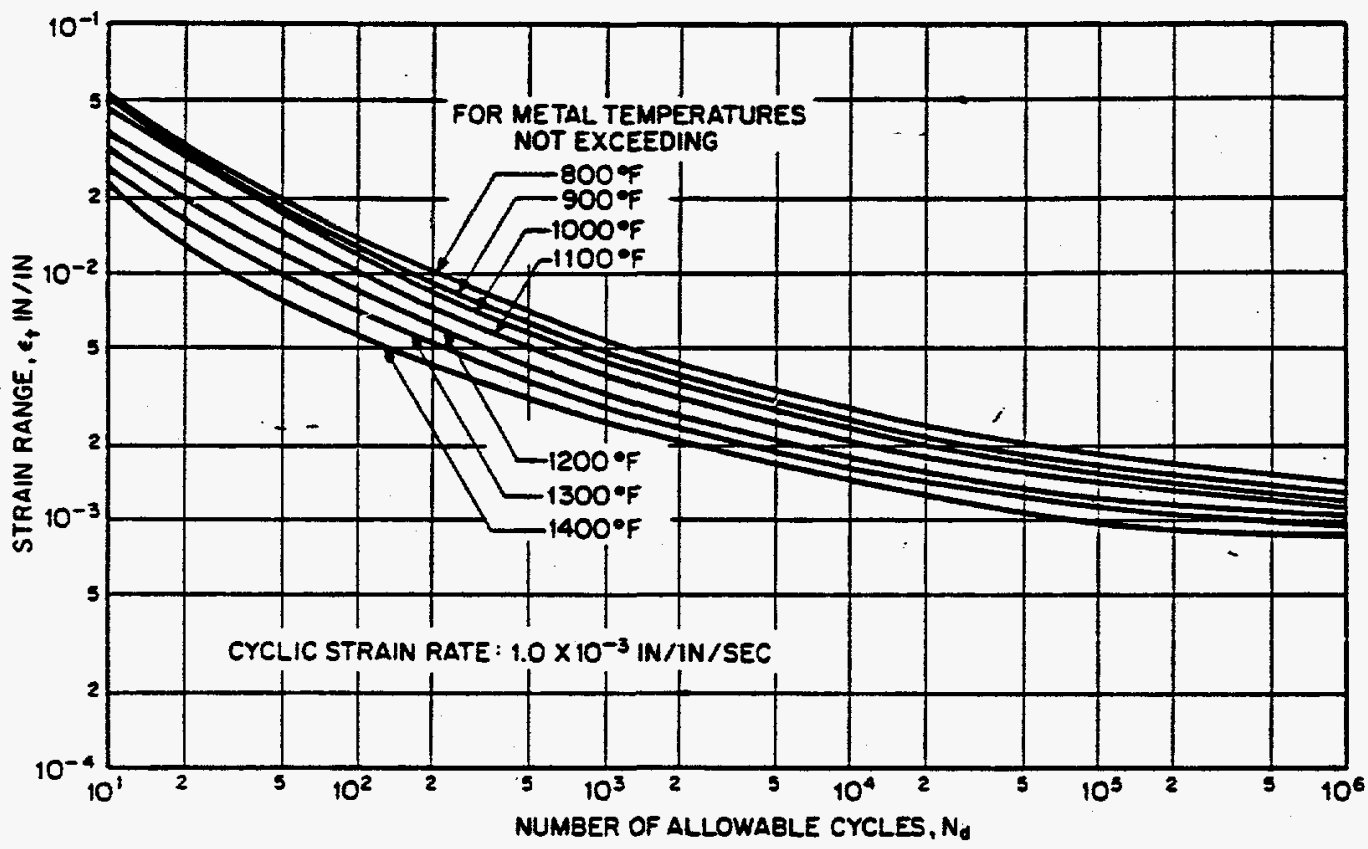

Fig. 3-7. Alloy $800 H$ - design fatigue strain range, $\epsilon_{\tau}$ 


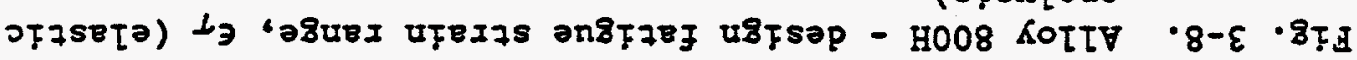

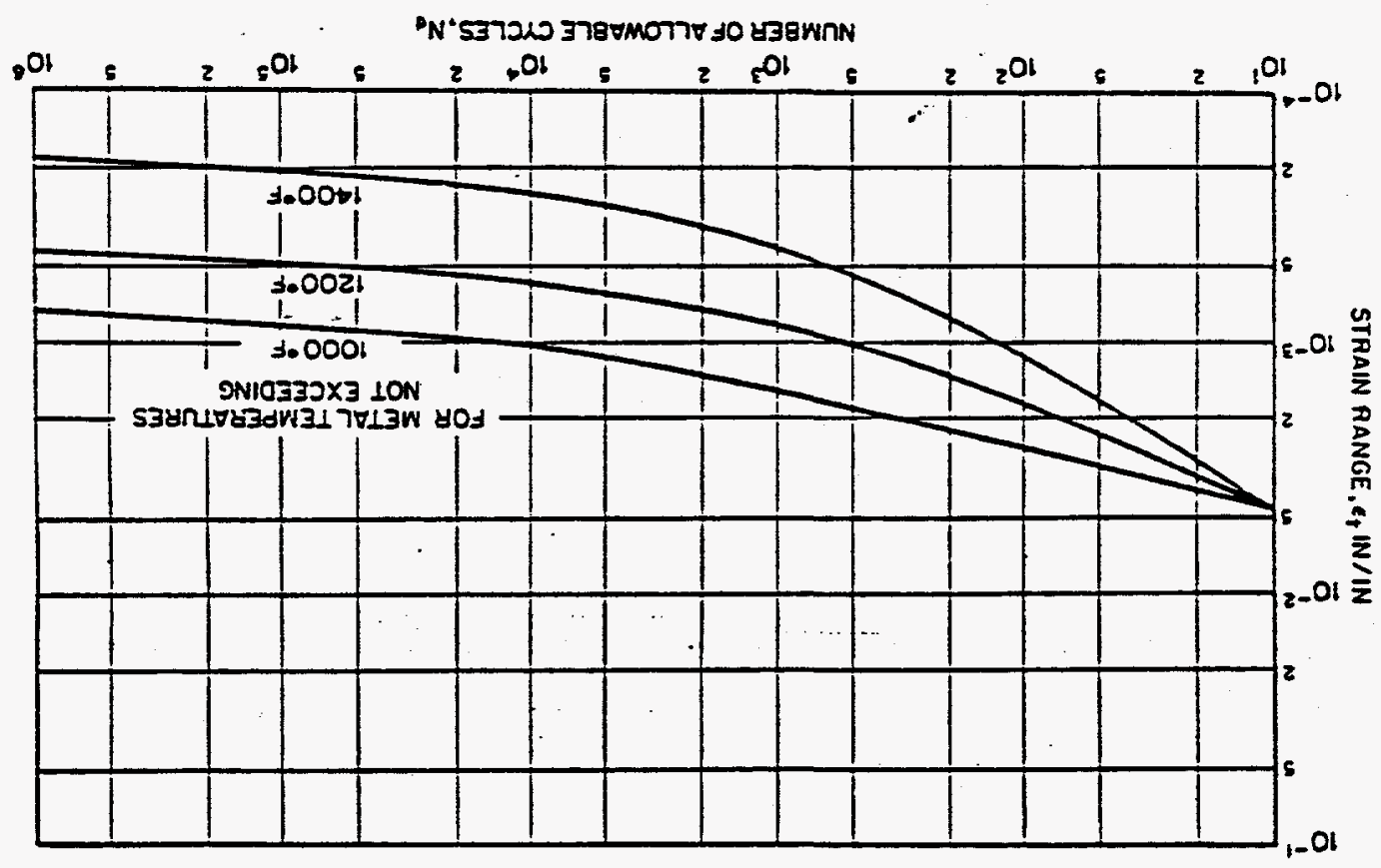

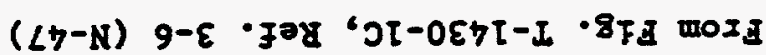


From Ref. 3-4

TEMPERATURE (DEG C)

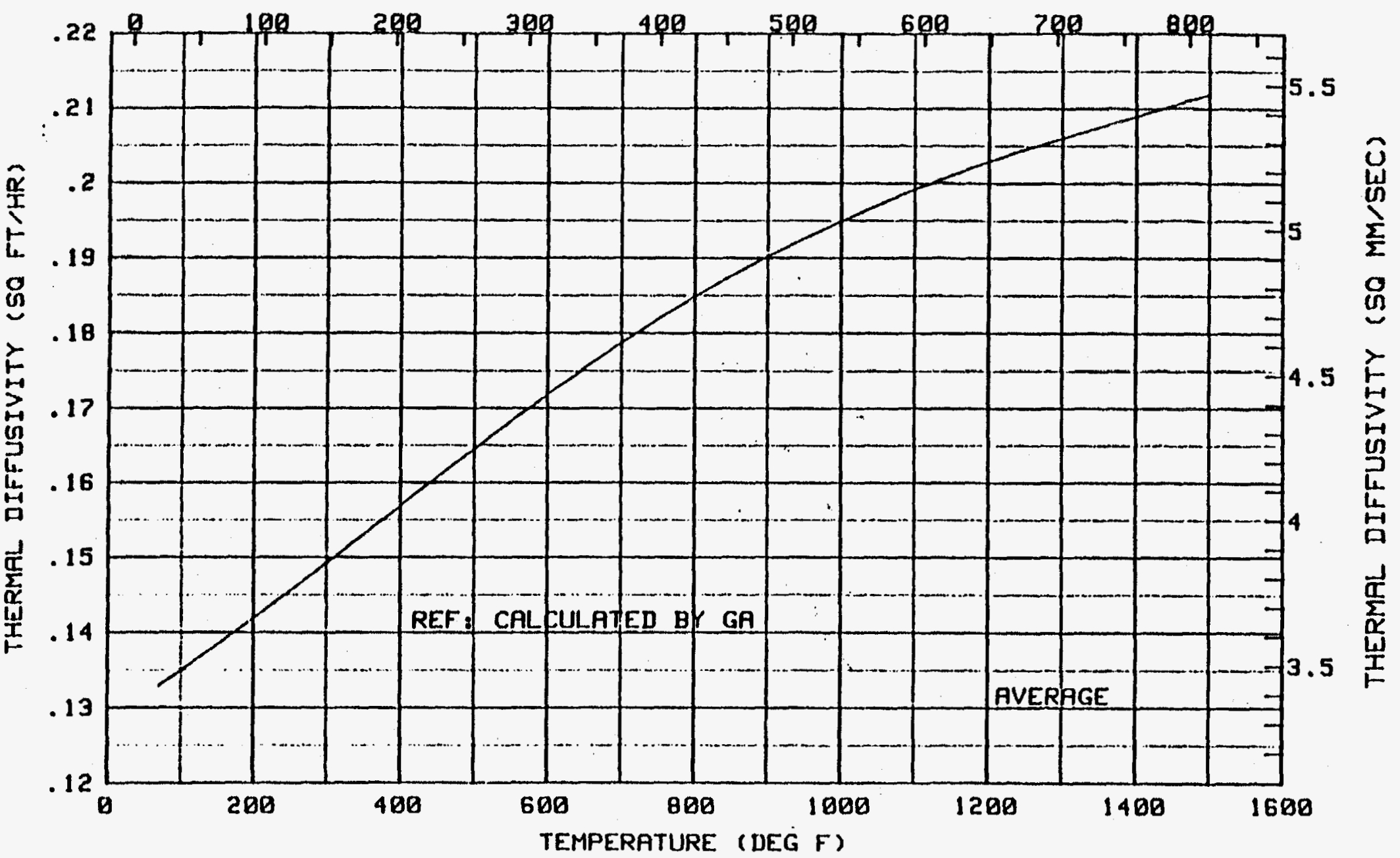

Fig. 3-9. Alloy 800 - thermal diffusivity 


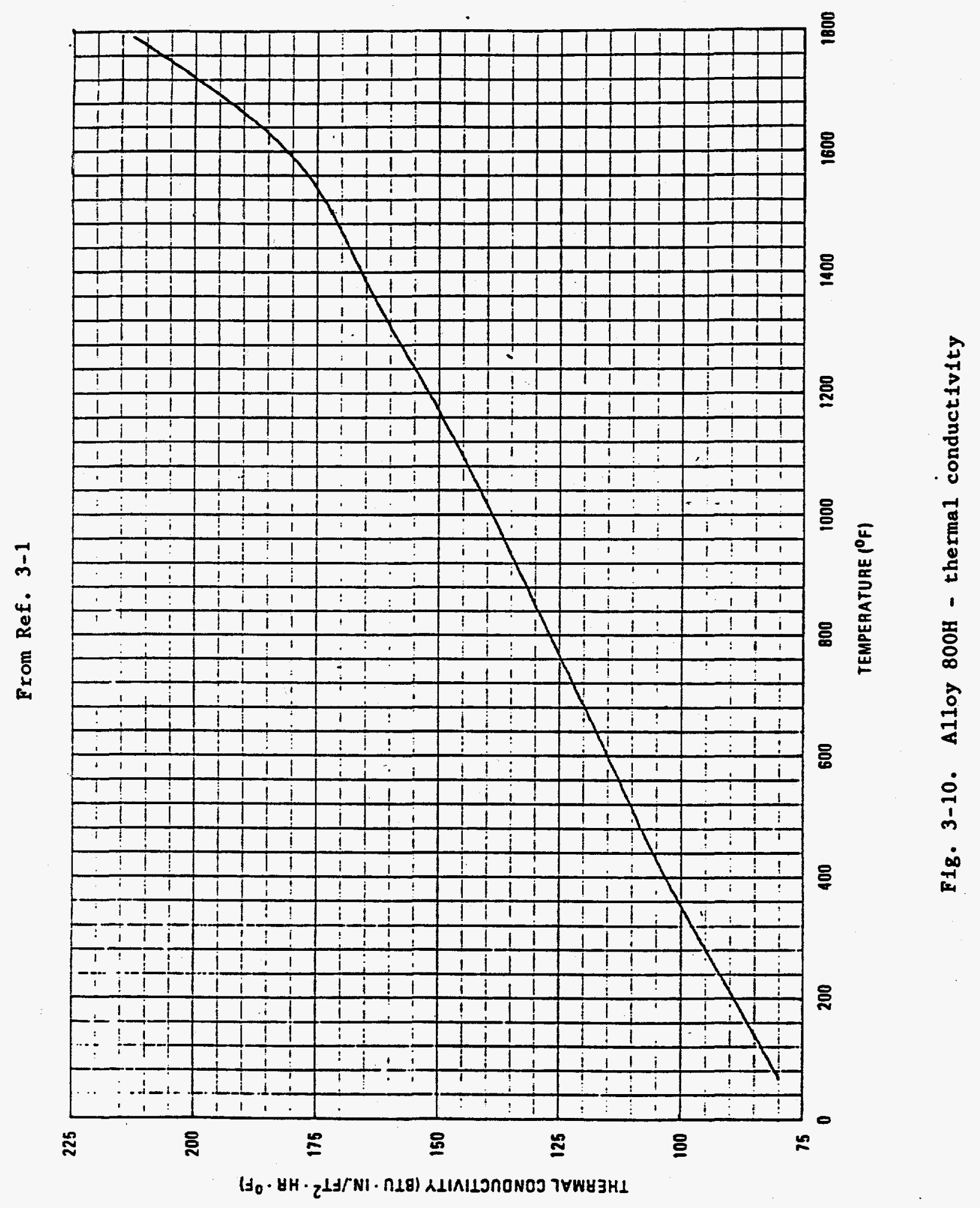




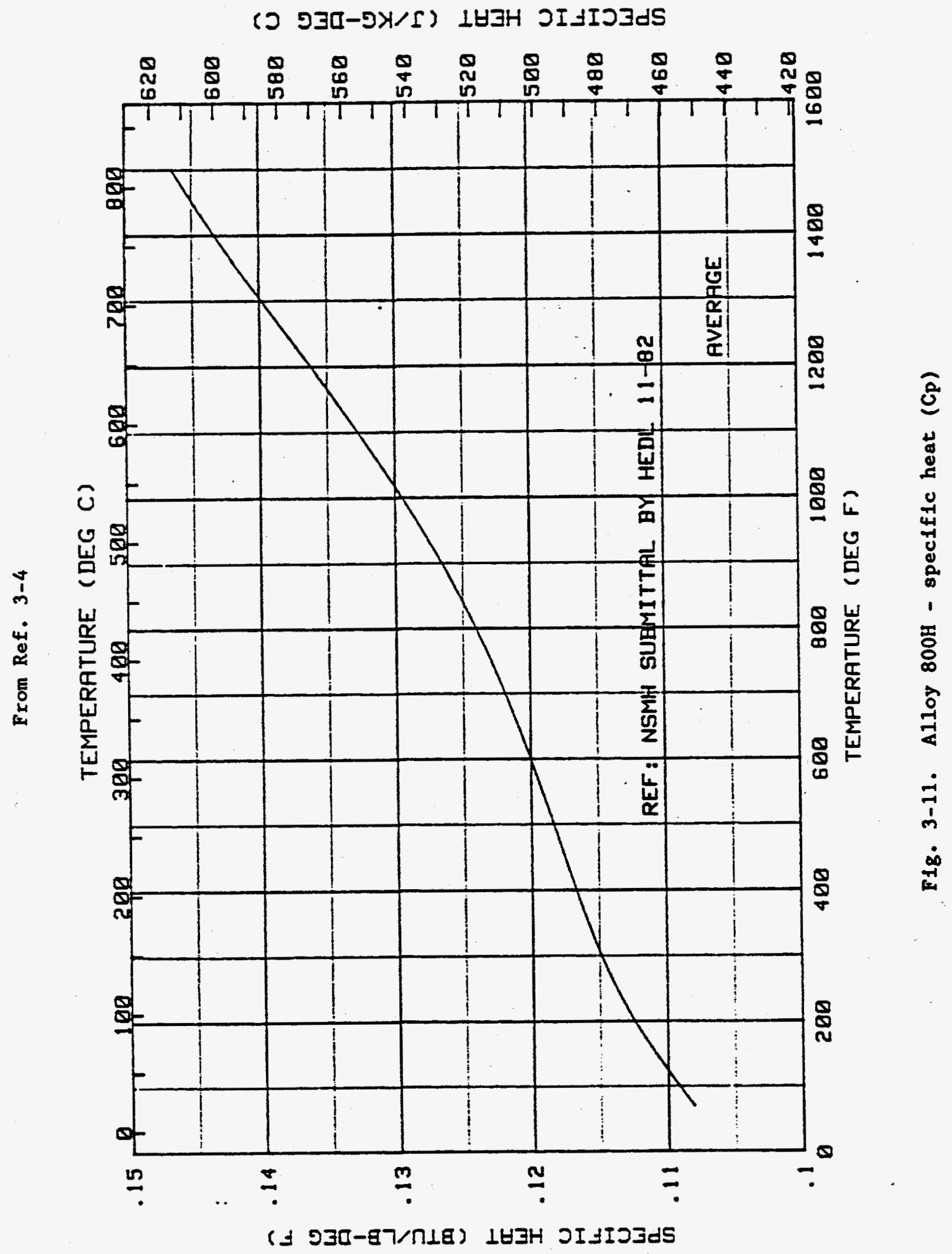


4. IOW ALLOY STEEL, 2-1/4 Cr - 1 MO

\subsection{PRODUCT FORMS AND APPLICABLE SPECIFICATIONS}

This product is available in many forms and compositions as shown In Tables 4-1 and 4-2, respectively.

\subsection{TIME-INDEPENDENT MECHANICAL PROPERTIES}

The following mechanical properties of 2-1/4 Cr - 1 Mo shall be used in design: ultimate strength $\left(S_{u}\right)$ (Table 4-3), yield strength $\left(S_{y}\right)$ (Table 4-3), design stress intensity $\left(S_{m}\right)$ (Table 4-3), and modulus of elasticity (E) (Table 4-4). The materlal 2-1/4 Cr - 1 Ho Grade 22 Class 1 is not included in the high-temperature Code Case N-201-1, but it is included in Code Case N-47 (Ref. 4-3).

\subsection{TIME-DEPENDENT MECHANICAI PROPERTIES}

The only metallic component to use $2-1 / 4 \mathrm{Cr}$ - 1 Mo is the metallic core support structure (per Table 1-1). This structure is to be designed to the ASME B\&PV Subsection NG and Code Case N-201 (per Table (-2).

Values of $s_{t}, S_{m t}$, and minimum $s_{R}$ for $2-1 / 4 \mathrm{Cr}-1$ Ho found in Tables $4-5,4-6$, and $4-7$ shall be used in design.

\subsection{FATIGUE IIFE}

The fatigue life of 2-1/4 Cr - 1 Mo steel presented In Fig. 4-1 and Table 4-8 shall be used in design. 


\subsection{THERMAL PROPERTIES}

The values of thermal diffusivity (a), thermal conductivity (k) (Table 4-9, Figs, 4-2, 4-3), and specific heat $\left(C_{p}\right)$ (Fig. 4-4) for 2-1/4 Cr - 1 Mo shall be used in design.

\subsection{ADDITIONAL MATERIAL PROPERTIES}

This section contains the coefficient of thermal expansion $(a)$ (Table 4-10) of 2-1/4 Cr - 1 Mo that shall be used in design.

\subsection{EFFECT OF PRIMARY COOLANT CHEMISTRY AND TEMPERATURES}

The effect of primary coolant chemistry and temperature is expected to be small on the mechanical properties of 2-1/4 Cr - 1 Mo at the design temperatures less than $850^{\circ} \mathrm{F}$ and can be neglected.

\subsection{EFFECTS OF IRRADIATION}

The irradiation effects on the mechanical properties of $2-1 / 4 \mathrm{Cr}-$ 1 Mo can be neglected when irradiated at temperatures below $800^{\circ} \mathrm{F}$ at total fluences of less than $1019 \mathrm{n} / \mathrm{cm}^{2}$.

\subsection{REFERENCES}

4-1. ASME Boiler and Pressure Vessel Code, Section III, Division 1, Appendices, 1986 Edition through the 1987 Addenda.

4-2. Wattier, J. B., "HTGR Data Manual (Metals and Ceramics)," DOEHTGR-85048, Rev. 0, June 1985.

4-3. ASME Boiler and Pressure Vessel Code Case N-47-23, "Class 1 Components in Elevated Temperature Service, Section III, Division 1," February 20, 1986.

4-4. ASME Boiler and Pressure Vessel Code, Section II, Material Specifications, Part A, "Ferrous," 1986 Edition through the 1987 Acdenda. 
TABLE 4-1

2-1/4 Cr - 1 MO: MINIMUM SPECIFIED ROOM TEMPERATURE TENSILE PROPERTIES, PRODUCT FORMS, AND ASME SPECIFICATIONS

\begin{tabular}{|c|c|c|c|c|c|}
\hline $\begin{array}{c}\text { ASME } \\
\text { Specification }\end{array}$ & Grade & Product Form & {$\left[\operatorname{ksi} \stackrel{\mathrm{S}_{\mathrm{u}}}{(\mathrm{MPa})]}\right.$} & [ksi & ' \\
\hline SA-182 & F22a & Fittings and valves & $60(414)$ & 30 & $(207)$ \\
\hline$S A-213$ & $\mathrm{~T}-22$ & Seamless tubes & $60(414)$ & 30 & $(207)$ \\
\hline$S A-335$ & P22 & Seamless pipe & $60(414)$ & 30 & $(207)$ \\
\hline$S A-336$ & $\mathbf{F 2 2 a}$ & Forgings & $60(414)$ & 30 & $(207)$ \\
\hline SA-369 & FP22 pipe & Forged and bored & $60(414)$ & 30 & $(207)$ \\
\hline$S A-387$ & 22 Class 1 & Plate & $60(414)$ & 30 & $(207)$ \\
\hline$S A-387$ & 22 Class 2 & Plate & $75(518)$ & 45 & $(311)$ \\
\hline
\end{tabular}

Note: Except for Grade 22 Class 2, all the above materials are permissible materials at elevated temperatures (above $700^{\circ} \mathrm{F}$ ) per Code Case N-47 (Ref. 4-3). 


\section{TABLE 4-2 \\ 2-1/4 Cr - 1 MO: CHEMICAL COMPOSITION (Percent By Welght)}

ASME Specification SA-387, Grade 22

$\begin{array}{ll}\text { C, maximum } & 0.15 \\ \text { Mn } & 0.25-0.66 \\ \text { P, maximum } & 0.035 \\ \text { S, maximum } & 0.035 \\ \text { S1, maximum } & 0.50 \\ \text { Cr } & 1.88-2.62 \\ \text { Mo } & 0.85-1.15 \\ \text { Fe } & \text { Balance }\end{array}$

Values from Ref. 4-4. 
TABLE 4-3

2-1/4 Cr - 1 Mo GRADE 22 CLASS 1: TENSILE ULTIMATE STRENGTH $\left(S_{u}\right)$, YIELD STRENGTH $\left(S_{y}\right)$, AND TIME-INDEPENDENT DESIGN

STRESS INTENSITY $\left(S_{m}\right)$

\begin{tabular}{cccc}
\hline $\begin{array}{c}\text { Temperature } \\
\left({ }^{\circ} \mathrm{F}\right)\end{array}$ & \multicolumn{3}{c}{ Strength (ksi) } \\
\cline { 2 - 4 } $\mathrm{S}_{\mathrm{y}}(\mathrm{a})$ & $\mathrm{S}_{\mathrm{u}}{ }^{\mathrm{b})}$ & $\mathrm{S}_{\mathrm{m}}(\mathrm{c})$ \\
\hline 100 & 30.0 & 60.0 & 20.0 \\
200 & 27.8 & 60.0 & 18.5 \\
300 & 27.1 & 58.2 & 18.1 \\
400 & 26.9 & 58.2 & 17.9 \\
500 & 26.9 & 58.2 & 17.9 \\
600 & 26.9 & 58.2 & 17.9 \\
700 & 26.9 & 58.2 & 17.9 \\
750 & 26.9 & 58.2 & 17.9 \\
800 & 26.7 & 58.2 & 17.8 \\
850 & 26.2 & 58.2 & 17.4 \\
900 & 25.7 & 58.2 & 17.1 \\
950 & 24.8 & 58.2 & 16.5 \\
1000 & 23.7 & 54.7 & 15.8
\end{tabular}

(a) Per Table I-2.1, Ref. 4-1 and

Table I-14.5 of Ref. 4-3.

(b) Per Table I-3.1, Ref. 4-1.

(c) Per Table I-1.1 of Ref. 4-1 for

$T \leq 700^{\circ} \mathrm{F}$; otherwise, $S_{m}$ based on two $S_{y} / 3$. 


$$
\begin{aligned}
& \text { TABLE } 4-4 \\
& 2-1 / 4 \text { CI }-1 \text { MO: MODULUS } \\
& \text { OF ELASTICITY }
\end{aligned}
$$

\begin{tabular}{cc}
\hline $\begin{array}{c}\text { Temperature } \\
\left({ }^{\circ} \mathrm{F}\right)\end{array}$ & $\begin{array}{c}\text { E } \times 10^{6(\mathrm{a})} \\
(\mathrm{ps} 1)\end{array}$ \\
\hline 70 & 30.6 \\
200 & 29.8 \\
300 & 29.4 \\
400 & 28.8 \\
500 & 28.3 \\
600 & 27.7 \\
700 & 27.1 \\
800 & 26.3 \\
\hline
\end{tabular}

(a) Per Table I-6.0, Ref. 4-1. 
TABLE 4-5

$2-1 / 4 \mathrm{Cr}-1 \mathrm{Mo}: s_{\mathrm{t}}-\underset{\text { ALLOWABLE STRESS INTENSITY VALUES }}{\text { (ks1) }}$

\begin{tabular}{|c|c|c|c|c|c|c|c|c|c|c|c|}
\hline $\begin{array}{c}\text { Temperature } \\
\left.\text { ( }{ }^{\circ} \mathrm{F}\right)\end{array}$ & $1 \mathrm{~h}$ & $10 \mathrm{~h}$ & $30 \mathrm{~h}$ & $10^{2} \mathrm{~h}$ & $3 \times 10^{2} \mathrm{~h}$ & $10^{3} \mathrm{~h}$ & $3 \times 10^{3} \mathrm{~h}$ & $10^{4} \mathrm{~h}$ & $3 \times 10^{4} \mathrm{~h}$ & $10^{5} \mathrm{~h}$ & $3 \times 10^{5} \mathrm{~h}$ \\
\hline $\begin{array}{l}700 \\
750 \\
800\end{array}$ & $\begin{array}{c}-- \\
35.3 \\
35.0\end{array}$ & $\begin{array}{l}35.5 \\
35.2 \\
33.2\end{array}$ & $\begin{array}{l}35.5 \\
34.6 \\
31.8\end{array}$ & $\begin{array}{l}35.5 \\
33.5 \\
30.4\end{array}$ & $\begin{array}{l}35.5 \\
32.5 \\
28.8\end{array}$ & $\begin{array}{l}35.5 \\
31.3 \\
26.8\end{array}$ & $\begin{array}{l}35.5 \\
29.7 \\
25.0\end{array}$ & $\begin{array}{l}35.5 \\
28.4 \\
23.0\end{array}$ & $\begin{array}{l}35.5 \\
26.6 \\
20.5\end{array}$ & $\begin{array}{l}35.5 \\
25.0 \\
18.0\end{array}$ & $\begin{array}{l}35.5 \\
23.3 \\
16.1\end{array}$ \\
\hline $\begin{array}{l}850 \\
900 \\
950\end{array}$ & $\begin{array}{l}32.3 \\
29.0 \\
25.0\end{array}$ & $\begin{array}{l}29.4 \\
25.5 \\
21.0\end{array}$ & $\begin{array}{l}28.0 \\
23.7 \\
19.3\end{array}$ & $\begin{array}{l}26.4 \\
22.0 \\
17.5\end{array}$ & $\begin{array}{l}25.0 \\
20.2 \\
16.3\end{array}$ & $\begin{array}{l}23.2 \\
18.5 \\
14.8\end{array}$ & $\begin{array}{l}21.0 \\
16.5 \\
13.2\end{array}$ & $\begin{array}{l}18.3 \\
14.4 \\
11.3\end{array}$ & $\begin{array}{r}16.3 \\
12.5 \\
9.7\end{array}$ & $\begin{array}{r}14.0 \\
10.9 \\
8.4\end{array}$ & $\begin{array}{r}12.3 \\
9.6 \\
7.3\end{array}$ \\
\hline $\begin{array}{l}1000 \\
1050 \\
1100\end{array}$ & $\begin{array}{l}20.7 \\
16.8 \\
13.6\end{array}$ & $\begin{array}{l}17.1 \\
13.8 \\
11.0\end{array}$ & $\begin{array}{l}15.5 \\
12.5 \\
10.0\end{array}$ & $\begin{array}{r}14.2 \\
11.2 \\
9.0\end{array}$ & $\begin{array}{r}13.1 \\
10.2 \\
8.2\end{array}$ & $\begin{array}{r}11.9 \\
9.3 \\
7.2\end{array}$ & $\begin{array}{r}10.4 \\
7.9 \\
6.2\end{array}$ & $\begin{array}{l}8.7 \\
6.7 \\
5.0\end{array}$ & $\begin{array}{l}7.5 \\
5.7 \\
4.1\end{array}$ & $\begin{array}{l}6.3 \\
4.7 \\
3.3\end{array}$ & $\begin{array}{l}5.2 \\
4.0 \\
2.7\end{array}$ \\
\hline $\begin{array}{l}1150 \\
1200\end{array}$ & $\begin{array}{r}10.8 \\
9.0\end{array}$ & $\begin{array}{l}8.8 \\
6.2\end{array}$ & $\begin{array}{l}8.0 \\
6.1\end{array}$ & $\begin{array}{l}7.2 \\
5.9\end{array}$ & $\begin{array}{l}6.3 \\
5.1\end{array}$ & $\begin{array}{l}5.4 \\
4.1\end{array}$ & $\begin{array}{l}-- \\
--\end{array}$ & -- & - & -- & -- \\
\hline
\end{tabular}

Per Table I-14.4D of Ref. 4-3 (N-47) for 2-1/4 Cr - 1 Mo Grade 22 Class 1. 
TABLE 4-6

$2-1 / 4 \mathrm{Cr}-1$ Mo: $s_{m t}$ - ALLOWABLE STRESS INTENSITY VALUES

(ks1)

\begin{tabular}{|c|c|c|c|c|c|c|c|c|c|c|c|}
\hline $\begin{array}{c}\text { Temperature } \\
\left({ }^{\circ} \mathrm{F}\right)\end{array}$ & $1 \mathrm{~h}$ & $10 \mathrm{~h}$ & $30 h$ & $10^{2} \mathrm{~h}$ & $3 \times 10^{2} h$ & $10^{3} \mathrm{~h}$ & $3 \times 10^{3} \mathrm{~h}$ & $10^{4} \mathrm{~h}$ & $3 \times 10^{4} \mathrm{~h}$ & $10^{5} \mathrm{~h}$ & $3 \times 10^{5} \mathrm{~h}$ \\
\hline $\begin{array}{l}700 \\
750 \\
800\end{array}$ & $\begin{array}{l}-- \\
17.9 \\
17.9\end{array}$ & $\begin{array}{l}17.9 \\
17.9 \\
17.9\end{array}$ & $\begin{array}{l}17.9 \\
17.9 \\
17.9\end{array}$ & $\begin{array}{l}17.9 \\
17.9 \\
17.9\end{array}$ & $\begin{array}{l}17.9 \\
17.9 \\
17.9\end{array}$ & $\begin{array}{l}17.9 \\
17.9 \\
17.9\end{array}$ & $\begin{array}{l}17.9 \\
17.9 \\
17.9\end{array}$ & $\begin{array}{l}17.9 \\
17.9 \\
17.9\end{array}$ & $\begin{array}{l}17.9 \\
17.9 \\
17.9\end{array}$ & $\begin{array}{l}17.9 \\
17.9 \\
17.9\end{array}$ & $\begin{array}{l}17.9 \\
17.9 \\
16.1\end{array}$ \\
\hline $\begin{array}{l}850 \\
900 \\
950\end{array}$ & $\begin{array}{l}17.6 \\
17.2 \\
16.7\end{array}$ & $\begin{array}{l}17.6 \\
17.2 \\
16.7\end{array}$ & $\begin{array}{l}17.6 \\
17.2 \\
16.7\end{array}$ & $\begin{array}{l}17.6 \\
17.2 \\
16.7\end{array}$ & $\begin{array}{l}17.6 \\
17.2 \\
16.3\end{array}$ & $\begin{array}{l}17.6 \\
17.2 \\
14.8\end{array}$ & $\begin{array}{l}17.6 \\
16.5 \\
13.2\end{array}$ & $\begin{array}{l}17.6 \\
14.4 \\
11.3\end{array}$ & $\begin{array}{r}16.3 \\
12.5 \\
9.7\end{array}$ & $\begin{array}{r}14.0 \\
10.9 \\
8.4\end{array}$ & $\begin{array}{r}12.3 \\
9.6 \\
7.3\end{array}$ \\
\hline $\begin{array}{l}1000 \\
1050 \\
1100\end{array}$ & $\begin{array}{l}15.9 \\
14.9 \\
13.6\end{array}$ & $\begin{array}{l}15.9 \\
13.8 \\
11.0\end{array}$ & $\begin{array}{l}15.5 \\
12.5 \\
10.0\end{array}$ & $\begin{array}{r}14.2 \\
11.2 \\
9.0\end{array}$ & $\begin{array}{r}13.1 \\
10.2 \\
8.2\end{array}$ & $\begin{array}{r}11.9 \\
9.3 \\
7.2\end{array}$ & $\begin{array}{r}10.4 \\
7.9 \\
6.2\end{array}$ & $\begin{array}{l}8.7 \\
6.7 \\
5.0\end{array}$ & $\begin{array}{l}7.5 \\
5.7 \\
4.1\end{array}$ & $\begin{array}{l}6.3 \\
4.7 \\
3.3\end{array}$ & $\begin{array}{l}5.2 \\
4.0 \\
2.7\end{array}$ \\
\hline $\begin{array}{l}1150 \\
1200\end{array}$ & $\begin{array}{r}10.8 \\
9.0\end{array}$ & $\begin{array}{l}8.8 \\
6.2\end{array}$ & $\begin{array}{l}8.0 \\
6.1\end{array}$ & $\begin{array}{l}7.2 \\
5.9\end{array}$ & $\begin{array}{l}6.3 \\
5.1\end{array}$ & $\begin{array}{l}5.4 \\
4.1\end{array}$ & -- & -- & $\begin{array}{l}-- \\
--\end{array}$ & -- & -- \\
\hline
\end{tabular}

Per Table I-14.3D of Ref. 4-3 (N-47) for 2-1/4 Cr - 1 Mo Grade 22 Class 1. 
TABLE 4-7

2-1/4 Cr - 1 Mo: EXPECTED MINIMUM STRESS-TO-RUPTURE VALUES (ksi)

\begin{tabular}{|c|c|c|c|c|c|c|c|c|c|c|}
\hline $\begin{array}{c}\text { Temperature } \\
\left({ }^{\circ} \mathrm{F}\right)\end{array}$ & $10 \mathrm{~h}$ & $30 \mathrm{~h}$ & $10^{2} \mathrm{~h}$ & $3 \times 10^{2} \mathrm{~h}$ & $10^{3} \mathrm{~h}$ & $3 \times 10^{3} \mathrm{~h}$ & $10^{4} \mathrm{~h}$ & $3 \times 10^{4} \mathrm{~h}$ & $10^{5} \mathrm{~h}$ & $3 \times 10^{5} \mathrm{~h}$ \\
\hline $\begin{array}{l}700 \\
750 \\
800 \\
850\end{array}$ & $\begin{array}{l}59.0 \\
58.0 \\
56.0 \\
52.0\end{array}$ & $\begin{array}{l}59.0 \\
57.0 \\
55.5 \\
50.5\end{array}$ & $\begin{array}{l}59.0 \\
56.0 \\
54.0 \\
46.0\end{array}$ & $\begin{array}{l}59.0 \\
54.6 \\
48.5 \\
40.5\end{array}$ & $\begin{array}{l}59.0 \\
53.0 \\
43.0 \\
35.0\end{array}$ & $\begin{array}{l}59.0 \\
51.2 \\
37.5 \\
31.0\end{array}$ & $\begin{array}{l}59.0 \\
48.0 \\
34.5 \\
27.5\end{array}$ & $\begin{array}{l}59.0 \\
43.3 \\
30.5 \\
24.0\end{array}$ & $\begin{array}{l}54.0 \\
37.5 \\
27.0 \\
21.0\end{array}$ & $\begin{array}{l}49.0 \\
34.1 \\
24.0 \\
18.5\end{array}$ \\
\hline $\begin{array}{r}900 \\
950 \\
1000\end{array}$ & $\begin{array}{l}46.0 \\
40.0 \\
31.5\end{array}$ & $\begin{array}{l}41.0 \\
35.0 \\
27.5\end{array}$ & $\begin{array}{l}36.0 \\
30.0 \\
24.0\end{array}$ & $\begin{array}{l}32.0 \\
26.0 \\
21.0\end{array}$ & $\begin{array}{l}28.0 \\
22.2 \\
17.9\end{array}$ & $\begin{array}{l}25.0 \\
19.5 \\
15.2\end{array}$ & $\begin{array}{l}21.6 \\
17.0 \\
13.1\end{array}$ & $\begin{array}{l}19.0 \\
14.6 \\
11.0\end{array}$ & $\begin{array}{r}16.4 \\
12.6 \\
9.4\end{array}$ & $\begin{array}{r}14.1 \\
11.0 \\
7.9\end{array}$ \\
\hline $\begin{array}{l}1050 \\
1100 \\
1150\end{array}$ & $\begin{array}{l}26.0 \\
21.0 \\
17.0\end{array}$ & $\begin{array}{l}22.5 \\
18.0 \\
14.1\end{array}$ & $\begin{array}{l}19.0 \\
15.1 \\
11.8\end{array}$ & $\begin{array}{r}16.5 \\
13.0 \\
9.8\end{array}$ & $\begin{array}{r}14.0 \\
10.8 \\
8.0\end{array}$ & $\begin{array}{c}12.0 \\
9.1 \\
--\end{array}$ & $\begin{array}{c}10.0 \\
7.5 \\
--\end{array}$ & $\begin{array}{l}8.3 \\
6.2 \\
--\end{array}$ & $\begin{array}{l}7.0 \\
5.0 \\
--\end{array}$ & $\begin{array}{l}5.8 \\
4.1 \\
--\end{array}$ \\
\hline 1200 & 13.5 & 11.1 & 9.2 & 7.6 & 6.2 & -. & -- & . $\quad-$ & -- & -- \\
\hline
\end{tabular}

Values per Table I-14.6D of Ref. 4-3 (N-47) for 2-1/4 Cr - 1 Mo Grade 22 Class 1. 
TABLE 4-8

2-1/4 CI - 1 Mo: DESIGN FATIGUE STRAIN RANGE, $\epsilon_{\tau}$

\begin{tabular}{|c|c|c|c|}
\hline \multirow{2}{*}{ No. of Cycles (a) } & \multicolumn{3}{|c|}{$\epsilon_{\tau}$ Strain Range (in./1n.) at Temperature } \\
\hline & $800^{\circ} \mathrm{F}$ & $900^{\circ}$ to $1100^{\circ} \mathrm{F}$ & $\leq 700^{\circ} \mathrm{F}$ \\
\hline 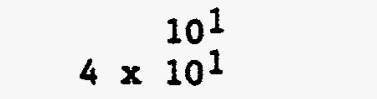 & $\begin{array}{l}0.056 \\
0.023\end{array}$ & $\begin{array}{l}0.040 \\
0.0163\end{array}$ & $\begin{array}{r}0.039 \\
--\end{array}$ \\
\hline $\begin{array}{ll} & 10^{2} \\
2 \times 10^{2} \\
4 \times 10^{2}\end{array}$ & $\begin{array}{l}0.013 \\
0.0094 \\
0.0070\end{array}$ & $\begin{array}{l}0.0097 \\
0.0070 \\
0.0056\end{array}$ & $\begin{array}{r}0.014 \\
-- \\
--\end{array}$ \\
\hline $\begin{array}{ll} & 10^{3} \\
2 \times 10^{3} \\
4 \times 10^{3}\end{array}$ & $\begin{array}{l}0.0052 \\
0.0044 \\
0.0040\end{array}$ & $\begin{array}{l}0.0042 \\
0.0039 \\
0.0035\end{array}$ & $\begin{array}{r}0.055 \\
-- \\
--\end{array}$ \\
\hline $\begin{array}{rr} & 10^{4} \\
2 \times 10^{4} \\
4 \times 10^{4}\end{array}$ & $\begin{array}{l}0.0032 \\
0.0026 \\
0.0023\end{array}$ & $\begin{array}{l}0.00265 \\
0.00215 \\
0.00182\end{array}$ & $\begin{array}{c}0.00253 \\
- \\
-\end{array}$ \\
\hline $\begin{array}{r}10^{5} \\
2 \times 10^{5} \\
4 \times 10^{5}\end{array}$ & $\begin{array}{l}0.00195 \\
0.00173 \\
0.00155\end{array}$ & $\begin{array}{l}0.00158 \\
0.00142 \\
0.00130\end{array}$ & $\begin{array}{c}0.00133 \\
\ldots \\
-\end{array}$ \\
\hline $10^{6}$ & 0.00137 & 0.00118 & 0.000833 \\
\hline
\end{tabular}

(a)Cycle strain rate: $4 \times 10^{-3}$ in./in./s. The values at $\mathrm{T}>700^{\circ} \mathrm{F}$ are from Table T-1420-1D of Ref. 4-3 (N-47). For $T \leq 700^{\circ} \mathrm{F}$, values were computed from Table I-9.0 of Ref. 4-1 using $E=30 \times 10^{6} \mathrm{psi}\left(\epsilon_{\tau}=2 \mathrm{~s}_{\mathrm{a}} / \mathrm{E}\right)$. 
TABLE 4-9

2-1/4 Cr - 1 MO: NOMINAI COEFFICIENTS OF THERMAI CONDUCTIVITY (k) AND THERMAL DIFFUSIVITY (a)

\begin{tabular}{|c|c|c|}
\hline Temperature $\left({ }^{\circ} \mathrm{F}\right)$ & $k(a)(b)$ & $a(a)(b)$ \\
\hline $\begin{array}{r}70 \\
100 \\
150 \\
200 \\
250\end{array}$ & $\begin{array}{l}20.9 \\
21.0 \\
21.2 \\
21.3 \\
21.4\end{array}$ & $\begin{array}{l}0.408 \\
0.397 \\
0.391 \\
0.385 \\
0.378\end{array}$ \\
\hline $\begin{array}{l}300 \\
350 \\
400 \\
450 \\
500\end{array}$ & $\begin{array}{l}21.5 \\
21.5 \\
21.5 \\
21.5 \\
21.4\end{array}$ & $\begin{array}{l}0.371 \\
0.364 \\
0.357 \\
0.349 \\
0.341\end{array}$ \\
\hline $\begin{array}{l}550 \\
600 \\
650 \\
700 \\
750\end{array}$ & $\begin{array}{l}21.3 \\
21.1 \\
20.9 \\
20.7 \\
20.5\end{array}$ & $\begin{array}{l}0.332 \\
0.323 \\
0.314 \\
0.305 \\
0.295\end{array}$ \\
\hline $\begin{array}{r}800 \\
850 \\
900 \\
950 \\
1000\end{array}$ & $\begin{array}{l}20.2 \\
20.0 \\
19.7 \\
19.4 \\
19.1\end{array}$ & $\begin{array}{l}0.285 \\
0.274 \\
0.264 \\
0.252 \\
0.241\end{array}$ \\
\hline $\begin{array}{l}1050 \\
1100 \\
1150 \\
1200 \\
1250\end{array}$ & $\begin{array}{l}18.8 \\
18.5 \\
18.3 \\
18.0 \\
17.7\end{array}$ & $\begin{array}{l}0.229 \\
0.217 \\
0.205 \\
0.192 \\
0.179\end{array}$ \\
\hline $\begin{array}{l}1300 \\
1350 \\
1400 \\
1450 \\
1500\end{array}$ & $\begin{array}{l}17.2 \\
16.4 \\
15.6 \\
15.4 \\
15.3\end{array}$ & $\begin{array}{l}0.163 \\
0.136 \\
0.075 \\
0.127 \\
0.197\end{array}$ \\
\hline
\end{tabular}

(a) $k$ is the thermal conductivity, $B t u / h-f t-{ }^{\circ} F$; and a is the thermal diffusivity, $f t^{2} / \mathrm{h}$ :

$$
a=\frac{k\left(B t u / h-f t-{ }^{\circ} F\right)}{\text { Density }\left(1 b / f t^{3}\right) \times \text { specific heat }\left(B t u / 1 b-{ }^{\circ} F\right)}
$$

(b) From Table I-4.0, Ref. 4-1. 
TABLE $4-10$

2-1/4 Cr - 1 MO: COEFFICIENT OF THERMAL EXPANSION

\begin{tabular}{cc}
\hline $\begin{array}{c}\text { Temperature } \\
\left({ }^{\circ} \mathrm{F}\right)\end{array}$ & $\begin{array}{c}\text { CTE (a) } \\
\left(\text { In. } / \text { In. } /{ }^{\circ} \mathrm{F} \times 10^{-6}\right)\end{array}$ \\
\hline 70 & -- \\
100 & 6.27 \\
150 & 6.41 \\
200 & 6.54 \\
250 & 6.65 \\
300 & 6.78 \\
350 & 6.88 \\
400 & 6.98 \\
450 & 7.07 \\
500 & 7.16 \\
550 & 7.24 \\
600 & 7.32 \\
650 & 7.41 \\
700 & 7.47 \\
750 & 7.55 \\
800 & 7.61 \\
\hline 600 & 6
\end{tabular}

(a) Per Table I-5.0, Ref. 4-1. 
$\stackrel{\circ}{\cong}$

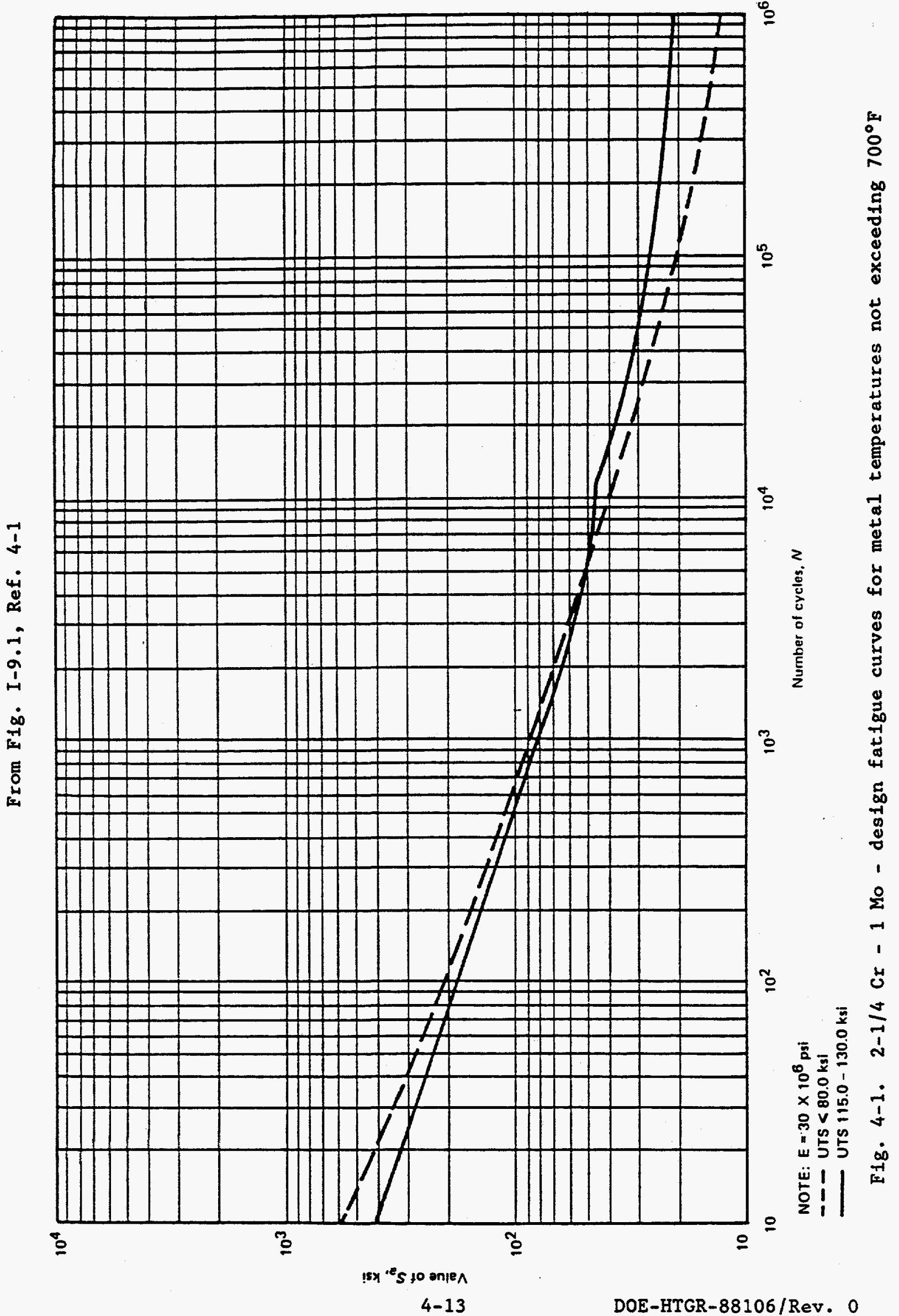




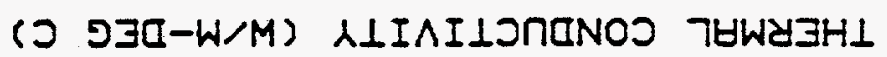

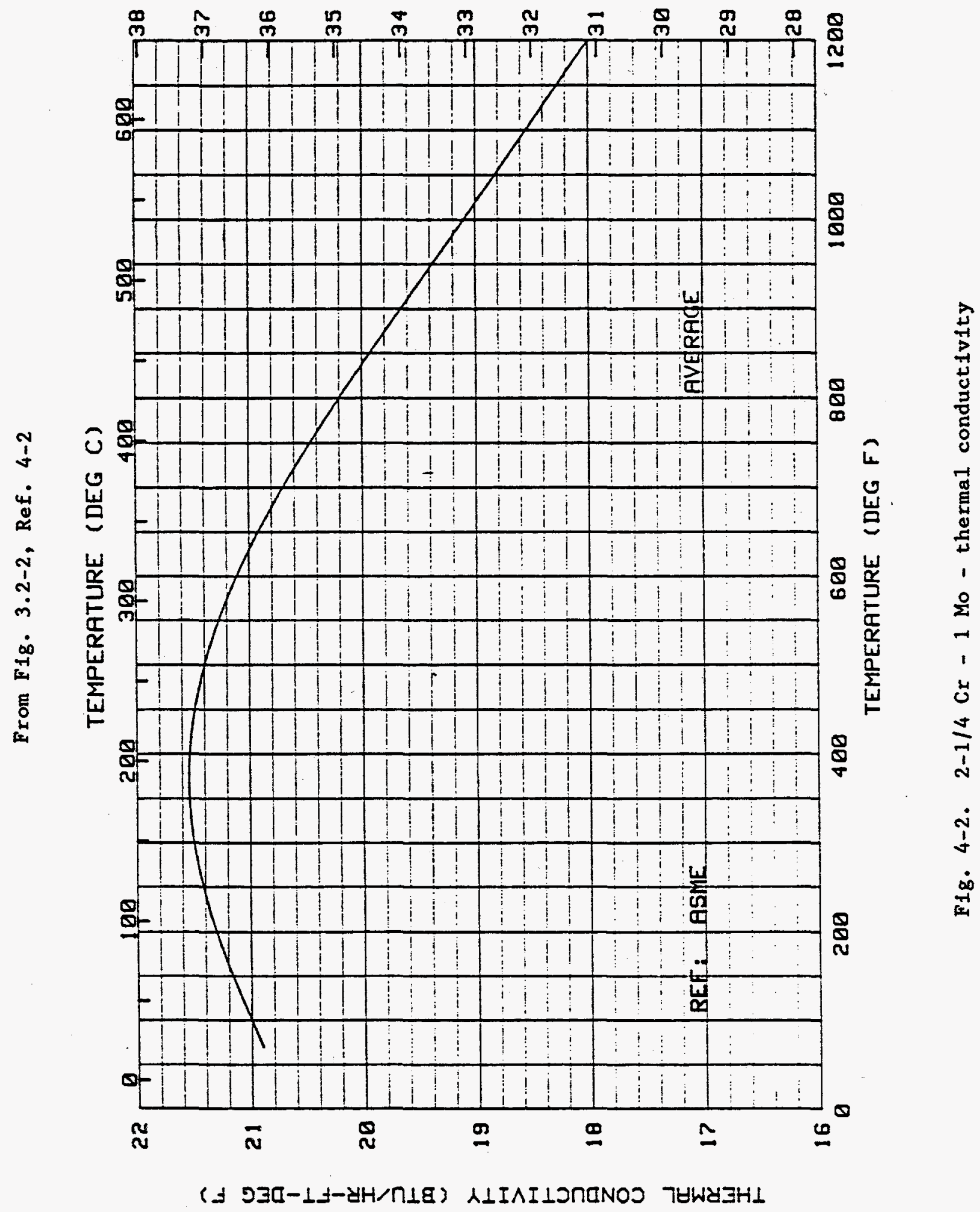




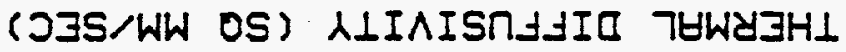

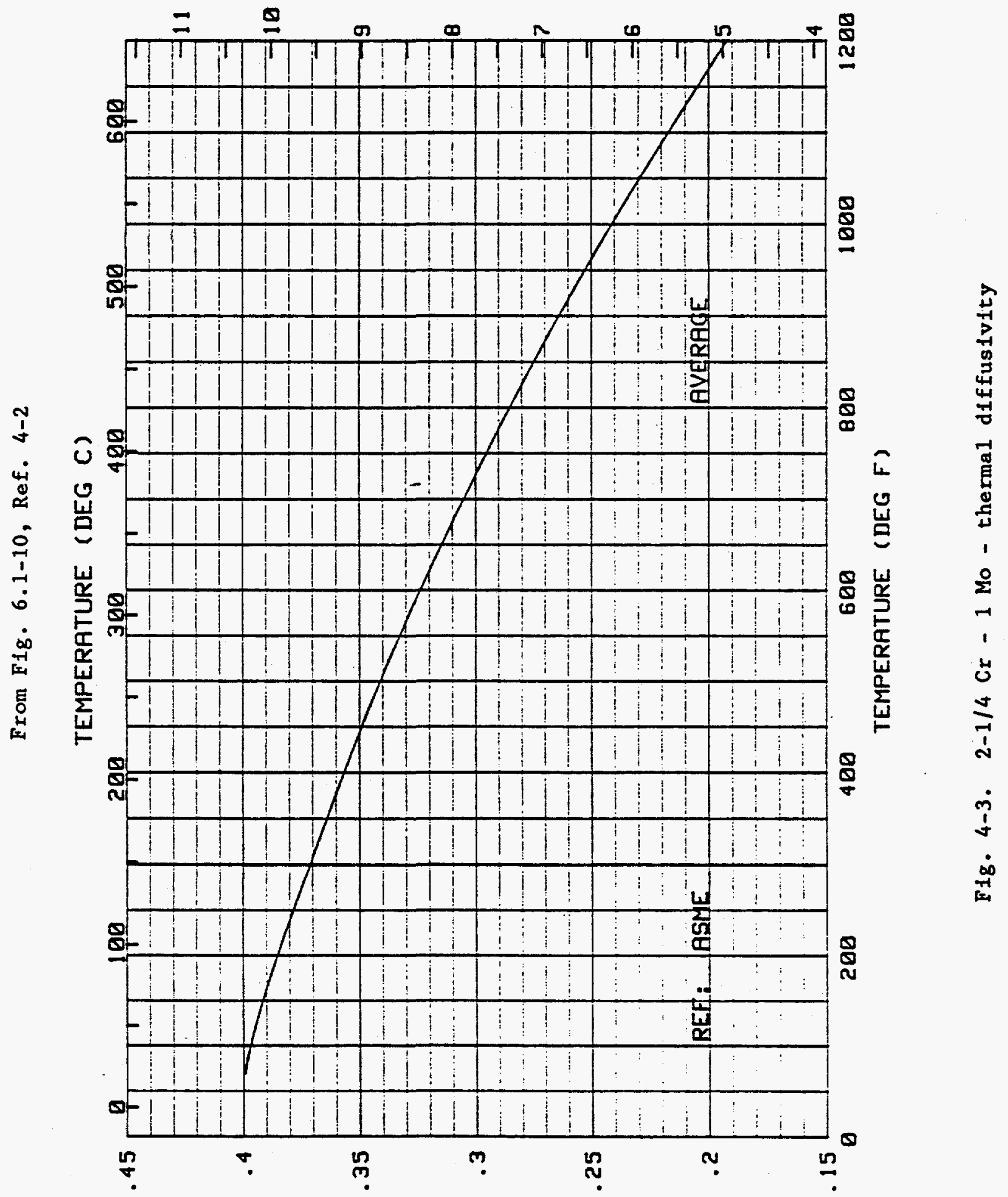

(ل)H/LA OS) NLIAISחAJIR TUWV $3 H 1$ 


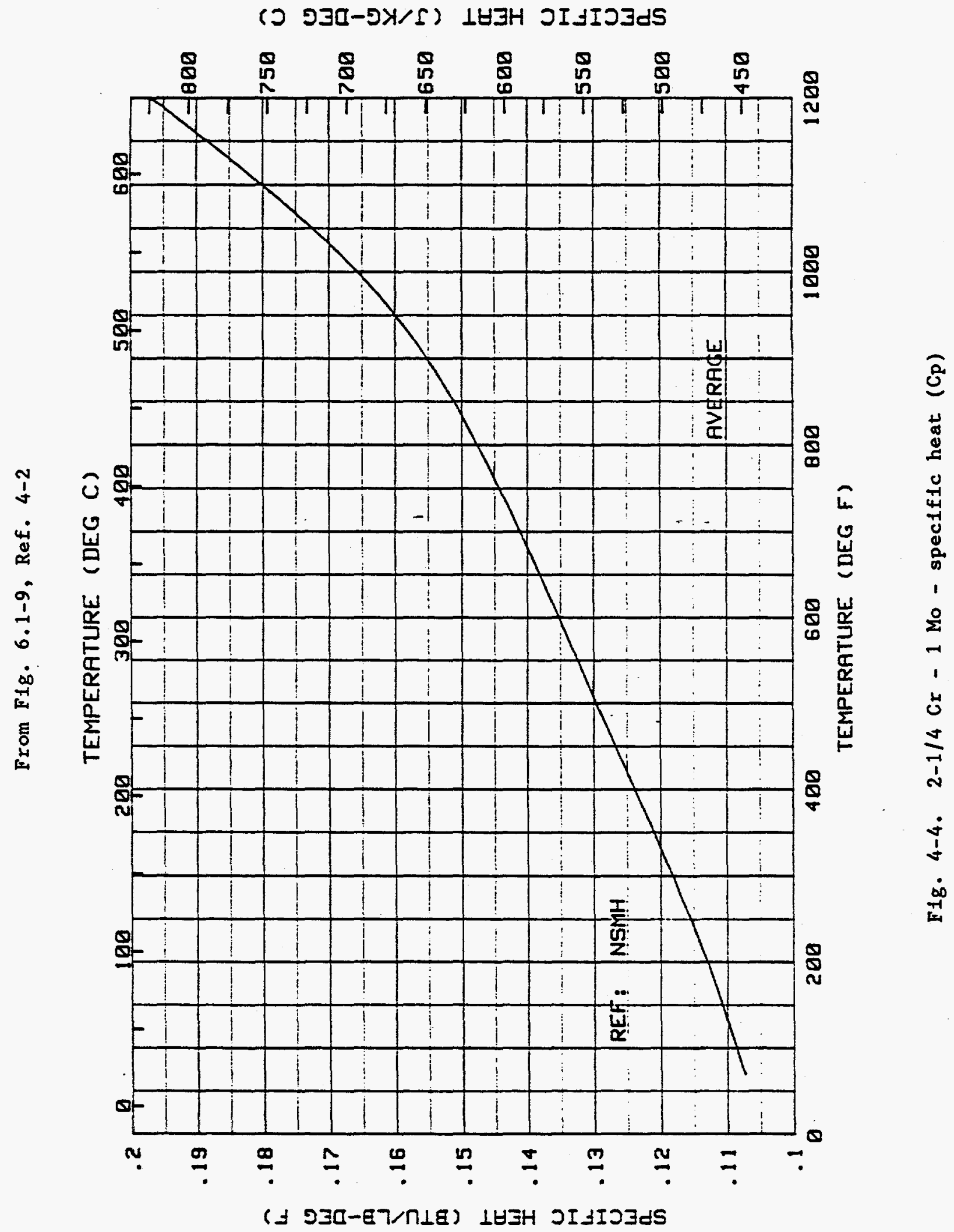


5. THREADED FASTENER MATERIAL SA-638 GRADE $660\left(26 \mathrm{~N} i-15 \mathrm{CI}_{I}-2 \mathrm{~T} i\right.$ )

Devices which are used to assemble structural elements of core support structures are referred to as threaded structural fasteners in Subsection NG (where the core support structures are located within a pressure-retaining boundary). For connections joining parts of pressure-retaining boundaries, NB-3230 (Ref. 5-1) rules apply.

This material is listed in Table I-1.1 (Ref. 5-2) and shall be used for applicable threaded structural fasteners in the MHTGR.

The data base is limited because of the maximum temperature conditions allowed by the Code. Until such time that the data base is expanded to include mechanical properties up to $1200^{\circ} \mathrm{F}$ for some of the MHTGR internal metallic operating/accident conditions use the values in this handbook.

\subsection{APPLICABLE SPECIFICATIONS}

The applicable specifications are given in Tables 5-1 and 5-2 is from Ref. 5-3.

\subsection{TIME-INDEPENDENT MECHANICAL PROPERTIES}

The threaded-structural-fastener material SA-638 Grade 660 design stress values to be used are presented in Table 5-3. The modulus of elasticity to be used is given in Table 5-4.

\subsection{TIME-DEPENDENT MECHANICAI PROPERTIES}

[IATER] 


\subsection{FATIGUE LIFE}

The fatigue life of SA-638 Grade 660 to be used is presented in Table 5-5.

\subsection{THERMAL PROPERTIES}

The following thermal properties shall be used : thermal conductivity (k) (Table 5-6), thermal diffusivity (Table 5-6), and coefficient of thermal expansion (Table 5-7).

5.6. EFFECT OF PRIMARY COOLANT CHEMISTRY AND TEMPERATURE

The effect on the mechanical properties of SA-638 Grade 660 can be neglected because there is not expected to be an effect in the MHTGR environment at design temperatures less than $700^{\circ} \mathrm{F}$.

\subsection{EFFECT OF IRRADIATION}

[IATER]

\subsection{REFERENCES}

5-1. ASME Boiler and Pressure Vessel Code, Section III, Division 1, Subsection NB - Class 1 Components, 1986 Edition through the 1987 Addenda.

5-2. ASME Boiler and Pressure Vessel Code, Section III, Division 1, Appendices, 1986 Edition through the 1987 Addenda.

5-3. ASME Boiler and Pressure Vessel Code, Section III, Material Specifications Part A, "Ferrous," 1986 Edition through the 1987 Addenda. 
TABLE 5-1

SA-638 GRADE 660: MECHANICAL PROPERTY REQUIREMENTS

$\begin{array}{lr}\text { Tensile strength, minimum } & 130,000 \\ \text { psi } & 895 \\ \text { MPa } & \\ \text { Yield strength (0.2\% offset), minimum } & 85,000 \\ \text { psi } & 585 \\ \text { MPa } & 15 \\ \text { Elongation in } 4 \mathrm{D} \text { minimum, } 7 & 18 \\ \text { Reduction of area, minimum, } 7 & 248 \text { minimum } \\ \text { Brinell hardness } & \\ \text { Stress-to-rupture at } 1200^{\circ} \mathrm{F}\left(649^{\circ} \mathrm{C}\right) & 23 \\ \text { and } 65,000 \text { psi }(460 \mathrm{MPa}) & 3 \\ \text { Minimum hours } & \\ \text { Elongation, } \% & \end{array}$

Note: Values in this table are from Ref. 5-2. 
TABLE 5-2

SA-638 GRADE 660: CHEMICAL COMPOSITION(a)

(Percent By Weight)

\begin{tabular}{llc}
\hline & \multicolumn{2}{c}{ Grade 660 (UNS K66286)(b) } \\
\cline { 2 - 3 } & $\begin{array}{c}\text { Ladle Analysis Range } \\
(\bar{l})\end{array}$ & $\begin{array}{c}\text { Check Analysis Over } \\
\text { or Under }\end{array}$ \\
\hline Carbon & 0.08 maximum & 0.01 over \\
Manganese & 2.00 maximum & 0.04 over \\
Silicon & 1.00 maximum & 0.05 over \\
Phosphorus & 0.040 maximum & 0.005 over \\
Sulfur & 0.030 maximum & 0.005 over \\
Chromium & 13.50 to 16.00 & 0.20 \\
Nickel & 24.00 to 27.00 & 0.20 \\
Molybdenum & 1.00 to 1.50 & 0.05 \\
Titanium & 1.90 to 2.35 & 0.05 \\
Copper & -- & 0.05 over \\
Aluminum & 0.35 maximum & 0.03 \\
Vanadium & 0.10 to 0.50 & 0.004 under \\
Boron & 0.0010 to 0.010 & 0.001 over \\
\hline
\end{tabular}

(a) Values from this table are from Ref. 5-2.

(b) New designation established in accordance with Recommended Practice E 527 and SAE J1086. 
TABLE 5-3

SA-638 GRADE 660: DESIGN STRESS INTENSITY

$\left(S_{m}\right)$ FOR THREADED STRUCTURAL FASTENER MATERIAI (a)

\begin{tabular}{cc}
\hline $\begin{array}{c}\text { Temperature } \\
\left({ }^{\circ} \mathrm{F}\right)\end{array}$ & $\begin{array}{c}\text { Design Stress Intensity } \\
\text { Values } \mathrm{S}_{\mathrm{m}}(\mathrm{b}) \\
(\mathrm{ksi})\end{array}$ \\
\hline 100 & 43.3 \\
200 & 43.3 \\
300 & 43.3 \\
400 & 43.3 \\
500 & 43.3 \\
600 & 43.3 \\
700 & 43.3 \\
\hline
\end{tabular}

(a) Minimum specified strength ratio $s_{y} / s_{u}=85 / 130$.

(b) Per Table I-1.1 (Ferritic Steels), Ref. 4-1. 
TABLE 5-4

SA-638 GRADE 660: MODULUS OF ELASTICITY

[LATER] 
TABLE 5-5

SA-638 GRADE 660: DESIGN FATIGUE LIMITS

[LATER] 
TABLE 5-6

NOMINAL COEFFICIENTS OF THERMAL CONDUCTIVITY

(k) AND THERMAL DIFFUSIVITY (a) FOR HIGH ALLOY STEEL GRADE 660

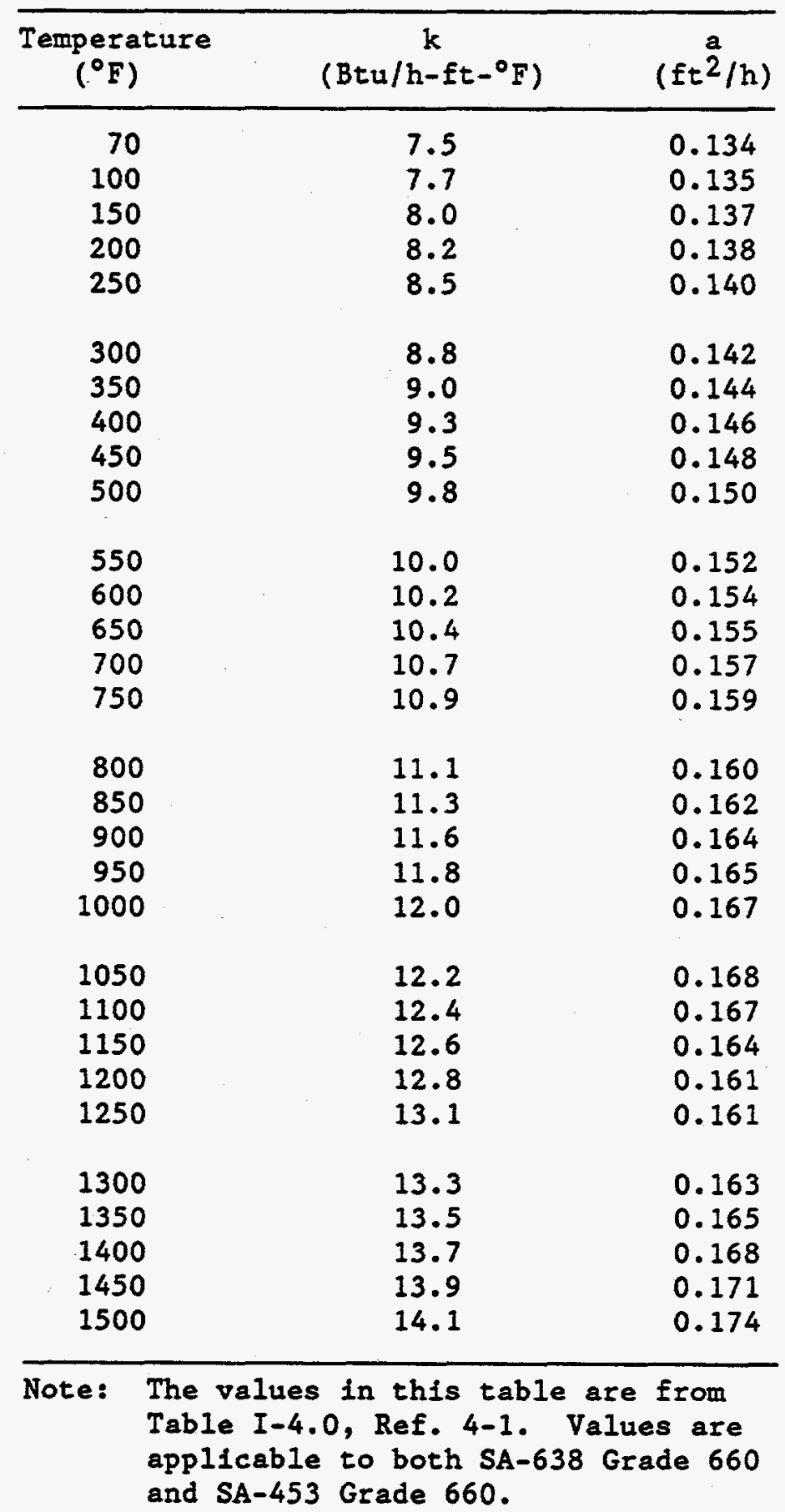


TABLE 5-7

COEFFICIENT OF THERMAL EXPANSION FOR

HIGH ALLOY STEEL GRADE 660

\begin{tabular}{ccc}
\hline $\begin{array}{c}\text { Temperature } \\
\left({ }^{\circ} \mathrm{F}\right)\end{array}$ & $\begin{array}{c}\text { Instant (a) } \\
\left(10^{-6} /{ }^{\circ} \mathrm{F}\right)\end{array}$ & Mean \\
\hline 70 & 8.22 & - \\
100 & 8.31 & 8.24 \\
150 & 8.46 & 8.32 \\
200 & 8.61 & 8.39 \\
250 & 8.75 & 8.47 \\
300 & 8.89 & 8.54 \\
350 & 9.02 & 8.62 \\
400 & 9.14 & 8.69 \\
450 & 9.26 & 8.76 \\
500 & 9.37 & 8.82 \\
550 & 9.48 & 8.88 \\
600 & 9.58 & 8.94 \\
650 & 9.68 & 9.0 \\
700 & 9.77 & 9.06 \\
750 & 9.85 & 9.11 \\
800 & 9.93 & 9.17 \\
\hline 69 & 9.96
\end{tabular}

(a) Per Table I-5.0, Ref. 4-1.

This is applicable to both SA-638

Grade 660 and SA-453 Grade 660 . 
6. BOLTING MATERIAI SA-193 GRADE B7 ( $1 \mathrm{Cr}-2 \mathrm{Mo})$

This bolting material is a low alloy steel listed in Table I-1.3 (Ref. 6-1).

6.1. APPLICABLE SPECIFICATIONS

The chemical compositions and mechanical properties are given in Tables 6-1 and 6-2 (Ref. 6-3).

6.2. TIME-INDEPENDENT MECHANICAL PROPERTIES

The bolting material SA-193 Grade B7 design stress values presented in Table $6-3$ and Fig. $6-1$ shall be used in design.

6.3. TIME-DEPENDENT MECHANICAL PROPERTIES

[IATER]

6.4. FATIGUE LIFE

[LATER]

\subsection{THERMAL PROPERTIES}

This section includes the following thermal properties to be used: thermal conductivity (k) (Fig, 6-2), thermal diffusivity (Fig, 6-3), and coefficient of thermal expansion (Table 6-4, Fig. 6-4). 


\subsection{EFFECT OF PRIMARY COOLANT CHEMISTRY AND TEMPERATURE}

The effect of primary coolant impurities can be neglected because no effect on the mechanical properties of SA-193 Grade B7 is expected in the MHTGR environment at design temperatures of less than $700^{\circ} \mathrm{F}$.

\subsection{EFFECT OF IRRADIATION}

[LATER]

\subsection{REFERENCES}

6-1. ASME Boiler and Pressure Vessel Code, Section III, Division 1, Appendices, 1986 Edition through the 1987 Addenda.

6-2. "HTGR Design Data Manual (Metals and Ceramics)," DOE-HTGR-85048, Rev. 0, June 1985.

6-3. ASME Boiler and Pressure Vessel Code, Section III, Material Specifications Part A, "Ferrous," 1986 Edition through the 1987 Addenda. 
TABLE 6-1

BOLTING MATERIAI SA-193 GRADE B7:

CHEMICAL COMPOSITION

(Percent By Weight)

Chromium-Molybdenum (AISI 4140, 4142, 4145, $4140 \mathrm{H}, 4142 \mathrm{H}$, and $4145 \mathrm{H}$ )

\begin{tabular}{lll}
\hline & \multicolumn{1}{c}{ Range(a) } & $\begin{array}{c}\text { Product Variation, } \\
\text { Over or Under }\end{array}$ \\
\hline $\mathrm{C}$ & 0.37 to $0.49(\mathrm{~b})$ & 0.02 \\
$\mathrm{Mn}$ & 0.65 to 1.10 & 0.04 \\
$\mathrm{P}, \max$ & 0.04 & 0.005 over \\
$\mathrm{S}, \max$ & 0.04 & 0.005 over \\
$\mathrm{Si}$ & 0.15 to 0.35 & 0.02 \\
$\mathrm{Cr}$ & 0.75 to 1.20 & 0.05 \\
Mo & 0.15 to 0.25 & 0.02 \\
\hline
\end{tabular}

(a) Per Table 10.1-2 of Ref. 6-2 which is from Ref. 6-3.

(b) For bar sizes over 3.5 to $4 \mathrm{in}$. inclusive, the carbon content may be $0.05 \%$ maximum. 
TABLE 6-2

BOLTING MATERIAL SA-193 GRADE B7: MINIMUM SPECIFIED ROOM TEMPERATURE TENSILE PROPERTIES AND SPECIFICATIONS

\begin{tabular}{|c|c|c|c|c|}
\hline $\begin{array}{l}\text { Diameter } \\
\text { (in.) }\end{array}$ & $\begin{array}{c}\left(S_{\mathrm{u}}\right) \\
\text { Ultimate Strength } \\
\text { Minimum } \\
\text { (ksi) }\end{array}$ & $\begin{array}{l}\left(S_{y}\right) \\
\text { Yield Strength } \\
\text { Minimum } \\
(\text { ksi })\end{array}$ & $\begin{array}{c}\text { Elongation } \\
(\%)\end{array}$ & $\begin{array}{c}\text { Reduction } \\
\text { of Area } \\
(\%)\end{array}$ \\
\hline$\leq 2.5$ & 125 & 105 & 16 & 50 \\
\hline$>2.5 \leq 4$ & 115 & 95 & 16 & 50 \\
\hline$>4 \leq 7$ & 100 & 75 & 18 & 50 \\
\hline
\end{tabular}

Per Table 10.1-1 of Ref. 6-2. The values of $S_{u}$ and $S_{y}$ are given in Table I-1.3 of Ref. 6-1. All values are given in Ref. 6-3. 
TABLE 6-3

BOLTING MATERIAL SA-193 GRADE B7:

DESIGN STRESS INTENSITY $\left(S_{m}\right)$ VALUES

Minimum Specified Strengths $\mathrm{S}_{\mathrm{y}} / \mathrm{S}_{\mathrm{u}}$ (ksi/ksi)

$$
\begin{gathered}
105 / 125 \quad 95 / 115 \quad 75 / 100 \\
\text { Bolt Diameter (In.) }
\end{gathered}
$$

\begin{tabular}{|c|c|c|c|c|c|c|}
\hline \multirow{2}{*}{$\frac{\begin{array}{c}\text { Temperature } \\
\left({ }^{\circ} \mathrm{F}\right)\end{array}}{100}$} & \multirow[b]{2}{*}{35.0} & \multicolumn{4}{|c|}{$\begin{array}{r}\text { Allowable }\left(\mathrm{S}_{\mathrm{m}}\right) \text { Values } \\
(\mathrm{ks} i)\end{array}$} & \\
\hline & & & 31.6 & & 25.0 & \\
\hline 200 & 32.6 & & 29.5 & & 23.3 & \\
\hline 300 & 31.4 & & 28.4 & & 22.4 & \\
\hline 400 & 30.5 & & 27.4 & & 21.8 & \\
\hline 500 & 29.5 & & 26.7 & & 21.0 & \\
\hline 600 & 28.4 & & 25.7 & & 20.3 & \\
\hline 650 & 27.4 & & 25.0 & & 19.7 & \\
\hline 700 & 26.8 & 25.0 & 24.3 & 23.0 & 19.2 & 18.7 \\
\hline 750 & 25.8 & 25.0 & 23.4 & 23.0 & 18.5 & 18.7 \\
\hline 800 & 24.6 & 25.0 & 22.3 & 23.0 & 17.5 & 18.7 \\
\hline 850 & -- & 25.0 & -- & 23.0 & -- & 18.7 \\
\hline 900 & -- & 23.7 & -- & 21.8 & -- & 18.7 \\
\hline 950 & -- & 21.7 & -- & 20.0 & -- & 17.4 \\
\hline 1000 & -- & 19.6 & -- & 18.0 & -- & 15.7 \\
\hline Ref. & (a) & (b) & (a) & (b) & (a) & (b) \\
\hline
\end{tabular}

$\begin{array}{lll}\leq 2.5 & >2.5 & >4 \\ & \leq 4 & \leq 7\end{array}$

(a) Section III, Division 1, Appendix I, Table I-1.3 ( $S_{\mathrm{m}}$ Values).

(b) Code Case N-253-4, Table C-1.1(b) (NC and ND Class 2 and class 3) for information only. 
TABLE 6-4

BOLTING MATERIAL SA-193 GRADE B7:

VARIOUS PROPERTY VALUES

\begin{tabular}{|c|c|c|c|c|}
\hline \multirow[b]{2}{*}{$\begin{array}{c}\text { Temperature } \\
\left({ }^{\circ} \mathrm{F}\right)\end{array}$} & \multicolumn{2}{|c|}{$\begin{array}{l}\alpha \text {, Coefficients of } \\
\text { Thermal Expansion }\end{array}$} & \multirow{2}{*}{$\begin{array}{l}k \text {, Thermal } \\
\text { Conductivity } \\
\text { (Btu/h-ft- }{ }^{\circ} \text { F) }\end{array}$} & \multirow{2}{*}{$\begin{array}{l}\text { a, Thermal } \\
\text { Diffusivity } \\
\left(\mathrm{ft}^{2} / \mathrm{h}\right)\end{array}$} \\
\hline & $\begin{array}{c}\text { Instant } \\
\left(10^{-6} /{ }^{\circ} \mathrm{F}\right)\end{array}$ & $\begin{array}{c}\text { Mean } \\
\left(10^{-6} /{ }^{\circ} \mathrm{F}\right)\end{array}$ & & \\
\hline $\begin{array}{r}70 \\
100 \\
150 \\
200 \\
250\end{array}$ & $\begin{array}{l}5.60 \\
5.83 \\
6.20 \\
6.55 \\
6.88\end{array}$ & $\begin{array}{l}5.73 \\
5.91 \\
6.09 \\
6.27\end{array}$ & $\begin{array}{l}24.2 \\
24.3 \\
24.4 \\
24.4 \\
24.3\end{array}$ & $\begin{array}{l}0.471 \\
0.464 \\
0.452 \\
0.439 \\
0.426\end{array}$ \\
\hline $\begin{array}{l}300 \\
350 \\
400 \\
450 \\
500\end{array}$ & $\begin{array}{l}7.18 \\
7.47 \\
7.73 \\
7.79 \\
8.18\end{array}$ & $\begin{array}{l}6.43 \\
6.59 \\
6.74 \\
6.89 \\
7.06\end{array}$ & $\begin{array}{l}24.2 \\
24.0 \\
23.9 \\
23.6 \\
23.4\end{array}$ & $\begin{array}{l}0.414 \\
0.402 \\
0.390 \\
0.378 \\
0.367\end{array}$ \\
\hline $\begin{array}{l}550 \\
600 \\
650 \\
700 \\
750\end{array}$ & $\begin{array}{l}8.38 \\
8.55 \\
8.70 \\
8.83 \\
8.94\end{array}$ & $\begin{array}{l}7.18 \\
7.28 \\
7.40 \\
7.51 \\
7.61\end{array}$ & $\begin{array}{l}23.1 \\
22.7 \\
22.3 \\
22.0 \\
21.6\end{array}$ & $\begin{array}{l}0.355 \\
0.344 \\
0.333 \\
0.320 \\
0.307\end{array}$ \\
\hline $\begin{array}{l}800 \\
850 \\
900 \\
950\end{array}$ & 9.02 & 7.71 & $\begin{array}{l}21.2 \\
20.9 \\
20.5 \\
20.1\end{array}$ & $\begin{array}{l}0.295 \\
0.283 \\
0.271 \\
0.259\end{array}$ \\
\hline $\begin{array}{l}1000 \\
1100 \\
1200\end{array}$ & & & $\begin{array}{l}19.8 \\
19.1 \\
18.2\end{array}$ & $\begin{array}{l}0.248 \\
0.225 \\
0.199\end{array}$ \\
\hline
\end{tabular}

Values are from Table 10.1-4 of Ref. 6-2. The values of $\alpha$ correspond to values for materlal group B in Table I-5.0 of Ref. 6-1. The values of $k$ and a are from material group $C$ in Table $I-4.0$ of Ref. 6-1. 
Per Fig. 10.1-5, Ref. 6-2

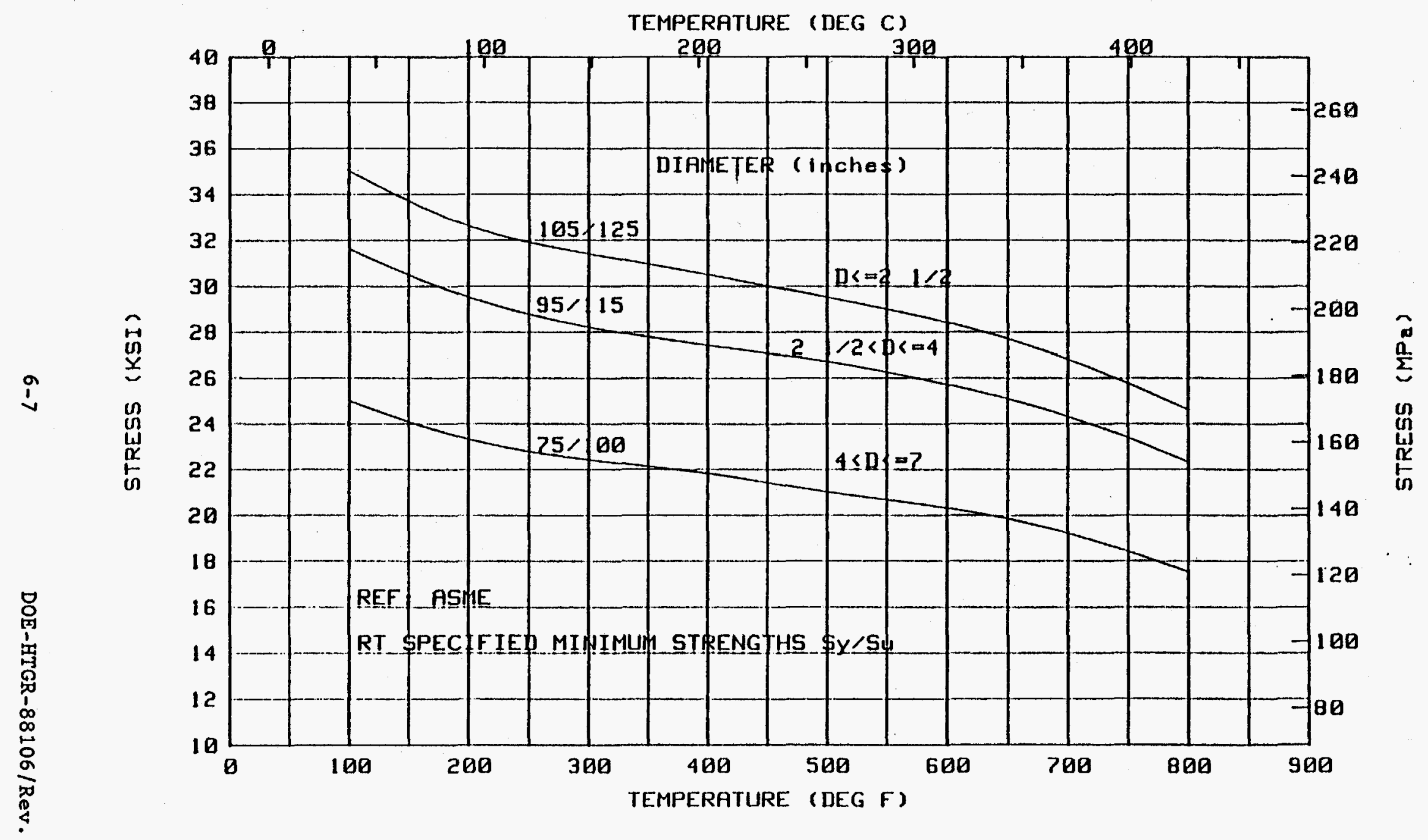

Fig. 6-1. Bolting SA-193 Grade B7 - stress intensity $\left(S_{m}\right)$ 
Per Fig. 10.1-8, Ref. 6-2

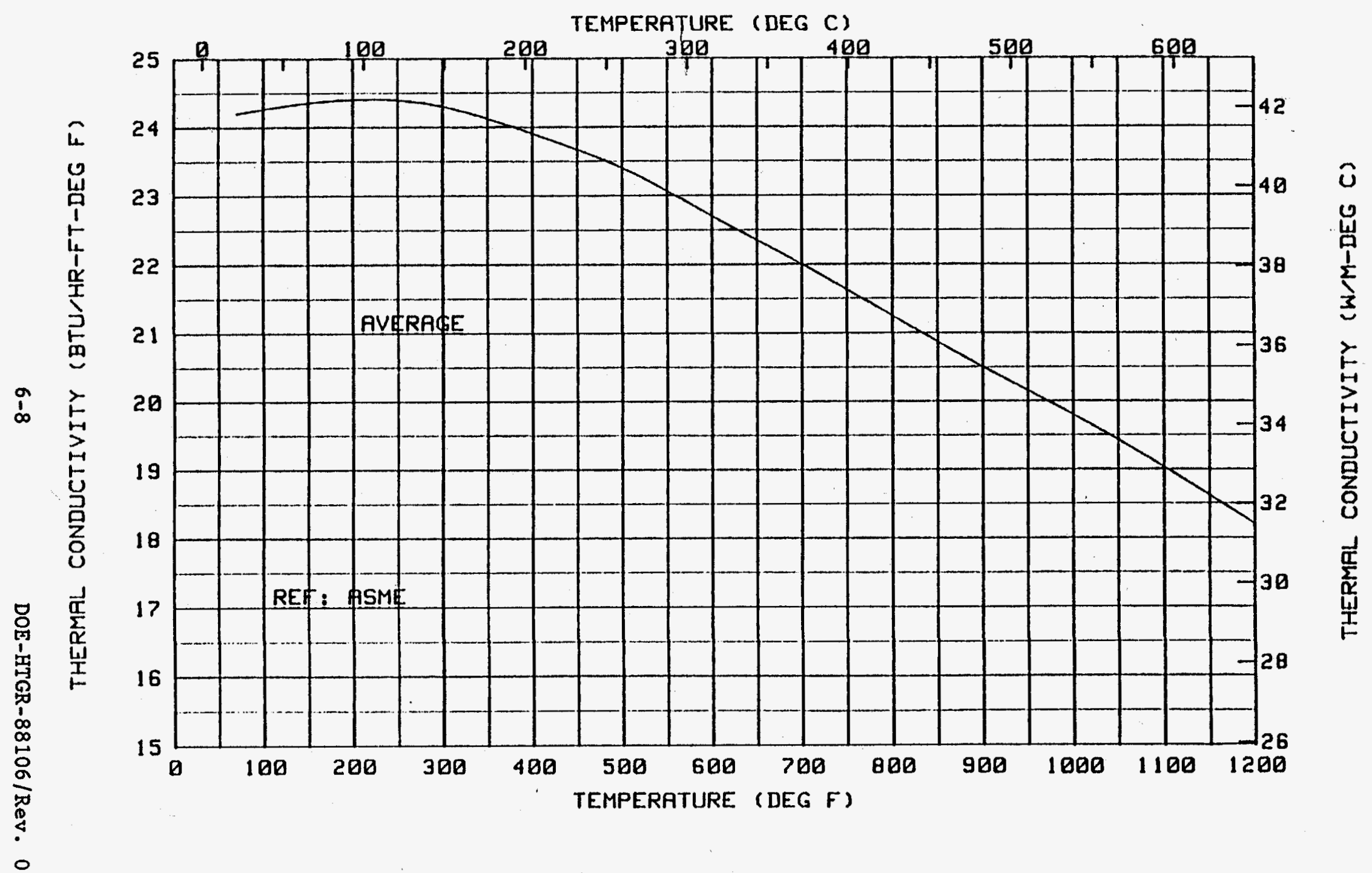

Fig. 6-2. Bolting SA-193 Grade B7 - thermal conductivity 


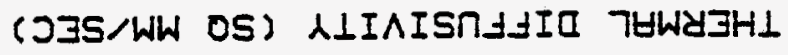

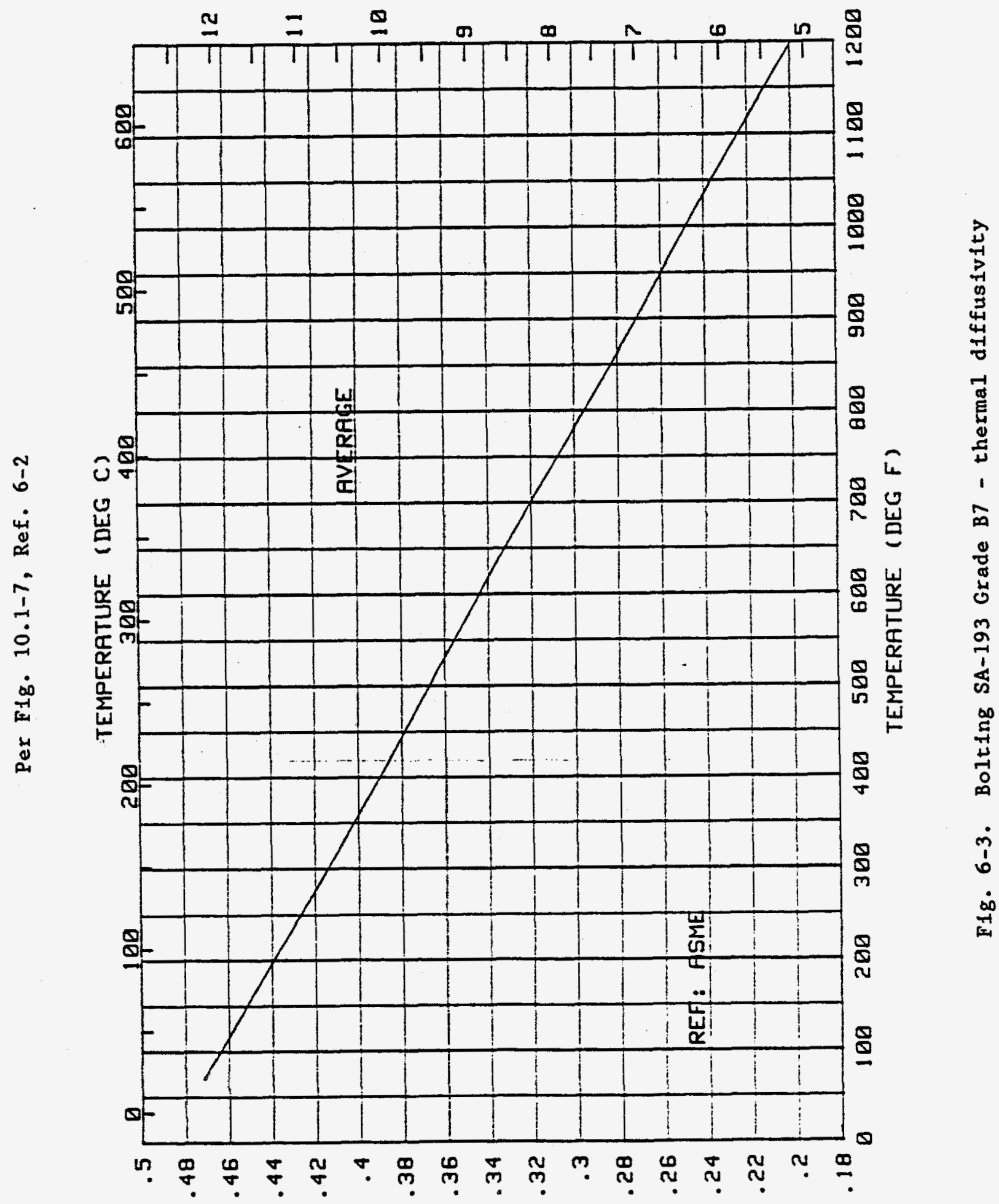

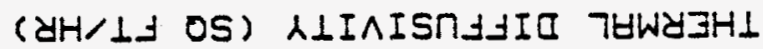




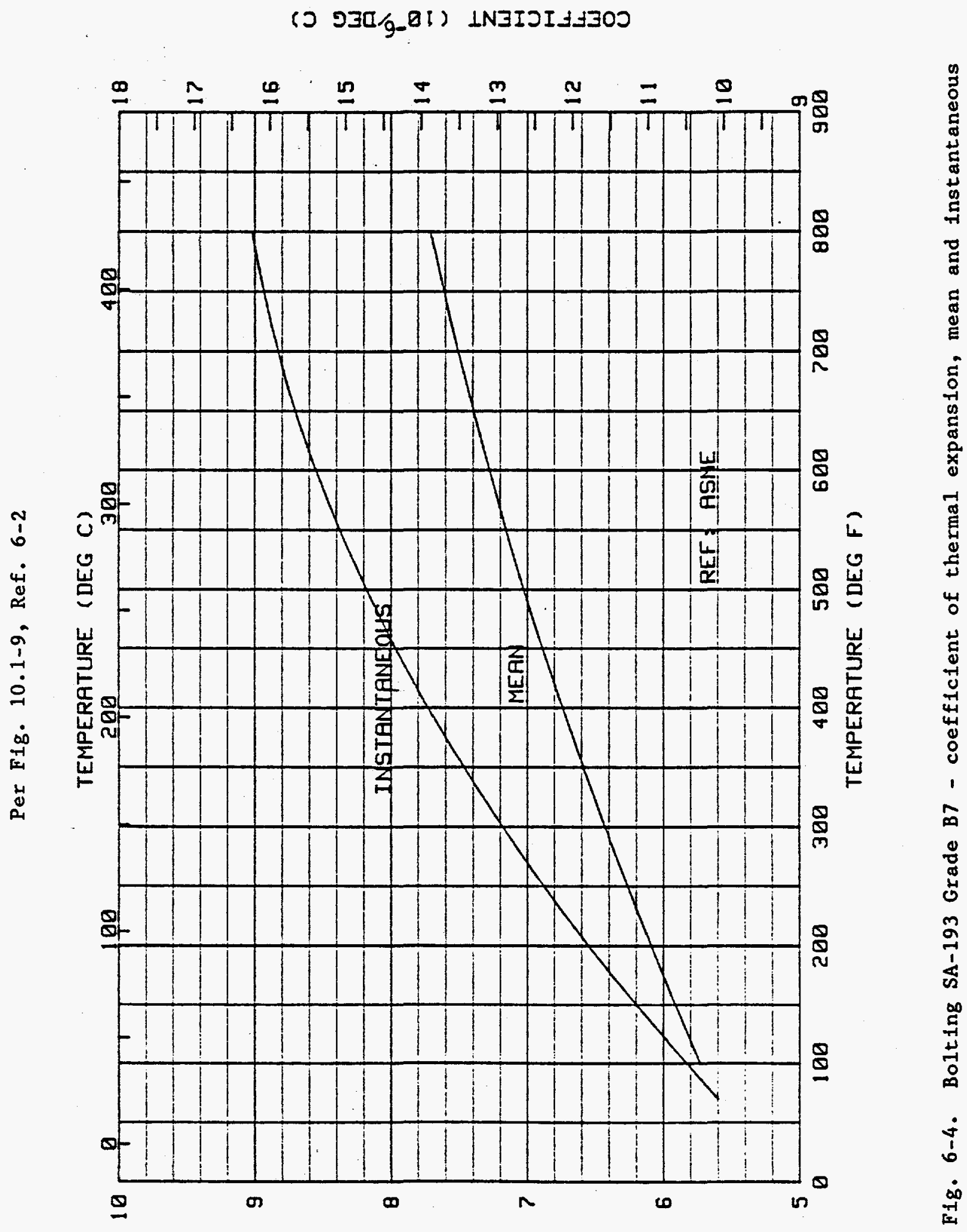

$( \pm 530 / 9-91)$ LNJIJI 37300 
7. BOLTING MATERIAL SA-453 GRADE 660 (26 Ni - $15 \mathrm{Cr}-2 \mathrm{Ti}$ )

This bolting material is a high alloy steel listed in Table I-1.3 (Ref. 7-1).

\subsection{APPLICABLE SPECIFICATIONS}

The chemical composition and mechanical properties shall be as given in Tables 7-1, 7-2, and 7-3 (Ref. 7-2).

7.2. TIME-INDEPENDENT MECHANICAL PROPERTIES

The bolting material SA-453 Grade 660 design stress values presented in Table 7-4 shall be used in design.

7.3. TIME-DEPENDENT MECHANICAL PROPERTIES

[LATER]

7.4. FATIGUE LIFE

[LATER]

\subsection{THERMAL PROPERTIES}

The following thermal properties shall be used in design: thermal conductivity (k) (Table 7-5), thermal diffusivity (Table 7-5), and coefficient of thermal expansion (Table 7-6). 


\subsection{EFFECT OF PRIMARY COOLANT CHEMISTRY AND TEMPERATURE}

The effect of primary coolant chemistry can be neglected because no effect on the mechanical properties of SA-453 Grade 660 is expected in the MHTGR environment at the design temperatures less than $700^{\circ} \mathrm{F}$.

\subsection{EFFECT OF IRRADIATION}

\section{[LATER]}

\subsection{REFERENCES}

7-1. ASME Boiler and Pressure Vessel Code, Section III, Division 1, Appendices, 1986 Edition through the 1987 Addenda.

7-2. ASME Boiler and Pressure Vessel Code, Section III, Material Specifications Part A, "Ferrous," 1986 Edition through the 1987 Addenda. 
TABLE 7-1

BOLTING MATERIAL SA-453 GRADE 660: CHEMICAL COMPOSITION

(Percent By Welght and Heat Treatment)

\begin{tabular}{|c|c|c|}
\hline & $\begin{array}{c}\text { Content } \\
\text { (z) }\end{array}$ & $\begin{array}{c}\text { Product Analysis Variation } \\
\text { Over or Under } \\
(\%)\end{array}$ \\
\hline Carbon & 0.08 maximum & 0.01 over \\
\hline Manganese & 2.00 maximum & 0.04 over \\
\hline Silicon & 1.00 maximum & 0.05 over \\
\hline Phosphorus & 0.040 maximum & 0.005 over \\
\hline Sulfur & 0.030 maximum & 0.005 over \\
\hline Chromium & 13.50 to 16.00 & 0.20 \\
\hline Nickel & 24.00 to 27.00 & 0.20 \\
\hline Molybdenum & 1.00 to 1.50 & 0.05 \\
\hline Titanium & 1.90 to 2.35 & 0.05 \\
\hline Columbium & -- & - \\
\hline Aluminum & 0.35 maximum & 0.05 over \\
\hline Vanadium & 0.10 to 0.50 & 0.03 \\
\hline Boron & 0.0010 to 0.010 & $\begin{array}{l}0.0004 \text { under } \\
0.001 \text { over }\end{array}$ \\
\hline Copper & -- & - \\
\hline
\end{tabular}

Per Ref. 7-2. 
TABLE 7-2

SA-453 GRADE 660: MECHANICAL PROPERTY REQUIREMENTS

\begin{tabular}{|c|c|c|c|c|c|c|c|}
\hline \multirow[b]{2}{*}{ Class } & \multicolumn{2}{|c|}{\begin{tabular}{l}
\multicolumn{1}{c}{$\left(S_{u}\right)$} \\
Ultimate \\
Tensile \\
Strength \\
Minimum \\
\end{tabular}} & \multicolumn{2}{|c|}{$\begin{array}{c}\left(S_{y}\right) \\
\text { Yield } \\
\text { Strength } \\
\text { Minimum } \\
\end{array}$} & \multirow{2}{*}{$\begin{array}{l}\text { Elongation in } \\
4 \times \text { Diameter } \\
\text { Minimmum } \\
(\%)\end{array}$} & \multirow{2}{*}{$\begin{array}{c}\text { Reduction of } \\
\text { Area } \\
\text { Minimum } \\
\text { (\%) }\end{array}$} & \multirow{2}{*}{$\begin{array}{l}\text { Brinell } \\
\text { Hardness No. }\end{array}$} \\
\hline & ksi & $\mathrm{MPa}$ & ksi & $\mathrm{MPa}$ & & & \\
\hline$A$ and $B$ & 130 & 895 & 85 & 585 & 15 . & 18 & 248 to 341 \\
\hline
\end{tabular}

Values of $S_{u}$ and $S_{y}$ are from Table I-1.3 of Ref. 7-1. All values given in Ref. 7-2. 
TABLE 7-3

SA-453 GRADE 660: STRESS-RUPTURE REQUIREMENTS

\begin{tabular}{|c|c|c|c|c|c|c|}
\hline \multirow[b]{2}{*}{ Class } & \multicolumn{2}{|c|}{$\begin{array}{c}\text { Test } \\
\text { Temperature }\end{array}$} & \multicolumn{2}{|c|}{$\begin{array}{l}\text { Stress } \\
\text { Minimum }\end{array}$} & \multirow{2}{*}{$\begin{array}{l}\text { Time to Rupture } \\
\text { Minimum } \\
\text { (h) }\end{array}$} & \multirow{2}{*}{$\begin{array}{l}\text { Elongation } \\
\text { Minimum } \\
(\%)\end{array}$} \\
\hline & $\left({ }^{\circ} \mathrm{C}\right)$ & $\left({ }^{\circ} \mathrm{F}\right)$ & ksi & $\mathrm{MPa}$ & & \\
\hline$A$ and $B$ & 650 & 1200 & 56 & 385 & 100 & 5 \\
\hline
\end{tabular}

Values from Ref. 7-2. 
TABLE $7-4$

BOLTING MATERIAL SA-453 GRADE 660: DESIGN STRESS INTENSITY VALUES $\left(S_{m}\right)$

\begin{tabular}{ccc}
\hline $\begin{array}{c}\text { Temperature } \\
\left({ }^{\circ} \mathrm{F}\right)\end{array}$ & $\begin{array}{c}\text { Allowable } \mathrm{S}_{\mathrm{m}} \\
(\mathrm{ksi})\end{array}$ & Values \\
\hline 100 & 28.3 & -- \\
200 & 27.6 & -- \\
300 & 27.3 & -- \\
400 & 27.2 & -- \\
500 & 27.1 & -- \\
600 & 28.0 & -- \\
700 & 26.8 & -- \\
800 & 26.6 & 27.0 \\
850 & -- & 27.0 \\
900 & -- & 28.0 \\
950 & -- & 26.8 \\
1000 & -- & 26.7 \\
Ref. & $(\mathrm{a})$ & $(\mathrm{b})$
\end{tabular}

(a) Per Table I-1.3 (Bolting), Ref. 7-1.

(b) Code Case N-253-4, Table D-2.1(b) - Allowable stress values for Class 2 bolting on vessels using -3200 rules. The high temperature code cases $\mathrm{N}-201-1$ (NG-Core Support Structure) and N-47-23 (NB-Class 1) do not include SA-453 Grade 660 in their bolting materials. (For information only.) 
TABLE 7-5

NOMINAL COEFFICIENTS OF THERMAL CONDUCTIVITY (k) AND THERMAL

DIFFUSIVITY (a) FOR HIGH

ALLOY STEEL GRADE 660

\begin{tabular}{|c|c|c|}
\hline $\begin{array}{c}\text { Temperature } \\
\left({ }^{\circ} \mathrm{F}\right)\end{array}$ & $\frac{k}{\left(B t u / h-f t-{ }^{\circ} F\right)}$ & $\left(f t^{2} / h\right)$ \\
\hline $\begin{array}{r}70 \\
100 \\
150 \\
200 \\
250\end{array}$ & $\begin{array}{l}7.5 \\
7.7 \\
8.0 \\
8.2 \\
8.5\end{array}$ & $\begin{array}{l}0.134 \\
0.135 \\
0.137 \\
0.138 \\
0.140\end{array}$ \\
\hline $\begin{array}{l}300 \\
350 \\
400 \\
450 \\
500\end{array}$ & $\begin{array}{l}8.8 \\
9.0 \\
9.3 \\
9.5 \\
9.8\end{array}$ & $\begin{array}{l}0.142 \\
0.144 \\
0.146 \\
0.148 \\
0.150\end{array}$ \\
\hline $\begin{array}{l}550 \\
600 \\
650 \\
700 \\
750\end{array}$ & $\begin{array}{l}10.0 \\
10.2 \\
10.4 \\
10.7 \\
10.9\end{array}$ & $\begin{array}{l}0.152 \\
0.154 \\
0.155 \\
0.157 \\
0.159\end{array}$ \\
\hline $\begin{array}{r}800 \\
850 \\
900 \\
950 \\
1000\end{array}$ & $\begin{array}{l}11.1 \\
11.3 \\
11.6 \\
11.8 \\
12.0\end{array}$ & $\begin{array}{l}0.160 \\
0.162 \\
0.164 \\
0.165 \\
0.167\end{array}$ \\
\hline $\begin{array}{l}1050 \\
1100 \\
1150 \\
1200 \\
1250\end{array}$ & $\begin{array}{l}12.2 \\
12.4 \\
12.6 \\
12.8 \\
13.1\end{array}$ & $\begin{array}{l}0.168 \\
0.167 \\
0.164 \\
0.161 \\
0.161\end{array}$ \\
\hline $\begin{array}{l}1300 \\
1350 \\
1400 \\
1450 \\
1500\end{array}$ & $\begin{array}{l}13.3 \\
13.5 \\
13.7 \\
13.9 \\
14.1\end{array}$ & $\begin{array}{l}0.163 \\
0.165 \\
0.168 \\
0.171 \\
0.174\end{array}$ \\
\hline
\end{tabular}

Note: The values in this table are from Table I-4.0, Ref. 7-1. Values are applicable to both SA-638 Grade 660 and SA-453 Grade 660 . 
TABLE 7-6

COEFFICIENT OF THERMAL EXPANSION FOR

HIGH ALLOY STEEL GRADE 660

\begin{tabular}{ccc}
\hline $\begin{array}{c}\text { Temperature } \\
\left({ }^{\circ} \mathrm{F}\right)\end{array}$ & $\begin{array}{c}\text { Instant (a) } \\
\left(10^{-6} /{ }^{\circ} \mathrm{F}\right)\end{array}$ & Mean \\
\hline 70 & 8.22 & -- \\
100 & 8.31 & 8.24 \\
150 & 8.46 & 8.32 \\
200 & 8.61 & 8.39 \\
250 & 8.75 & 8.47 \\
300 & 8.89 & 8.54 \\
350 & 9.02 & 8.62 \\
400 & 9.14 & 8.69 \\
450 & 9.26 & 8.76 \\
500 & 9.37 & 8.82 \\
550 & 9.48 & 8.88 \\
600 & 9.58 & 8.94 \\
650 & 9.68 & 9.0 \\
700 & 9.77 & 9.06 \\
750 & 9.85 & 9.11 \\
800 & 9.93 & 9.17 \\
\hline 619 & &
\end{tabular}

(a) Per Table I-5.0, Ref. 7-1.

This is applicable to both SA-638

Grade 660 and SA-453 Grade 660 . 